\title{
Data report: consolidation, permeability, and fabric of sediments from the Nankai continental slope, IODP Sites C0001, C0008, and C0004'
}

\author{
Demian Saffer, ${ }^{2}$ Junhua Guo, ${ }^{3}$ Michael B. Underwood, ${ }^{3}$ William Likos, ${ }^{4}$ Robert M. Skarbek, ${ }^{2}$ \\ Insun Song, ${ }^{2,5}$ and Marie Gildow ${ }^{2}$
}

\section{Chapter contents}

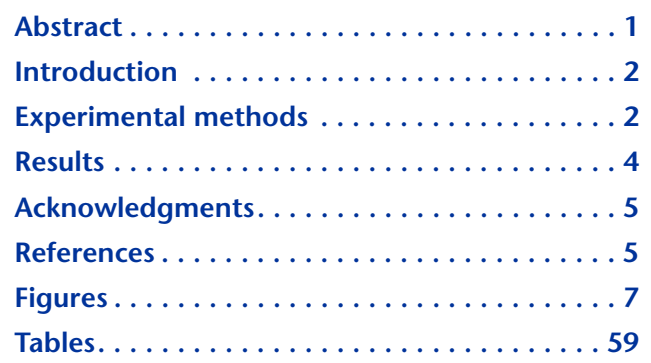

'Saffer, D., Guo, J., Underwood, M.B., Likos, W., Skarbek, R.M., Song, I., and Gildow, M., 2011. Data report: consolidation, permeability, and fabric of sediments from the Nankai continental slope, IODP Sites C0001, C0008, and C0004. In Kinoshita, M., Tobin, H., Ashi, J., Kimura, G., Lallemant, S., Screaton, E.J., Curewitz, D., Masago, H., Moe, K.T., and the Expedition 314/315/316 Scientists, Proc. IODP, 314/315/316: Washington, DC (Integrated Ocean Drilling Program Management International, Inc.).

doi:10.2204/iodp.proc.314315316.218.2011

${ }^{2}$ Rock and Sediment Mechanics Laboratory, The Pennsylvania State University, University Park PA 16802, USA. Correspondence author: dms45@psu.edu

${ }^{3}$ Department of Geological Sciences, University of Missouri, Columbia MO 65211, USA.

${ }^{4}$ Department of Civil and Environmental Engineering, University of Missouri, Columbia MO 65211, USA.

${ }^{5}$ Korea Institute of Geoscience and Mineral Resources (KIGAM), 92 Gwahang-No, Yuseong, Daejon 305-350, Republic of Korea.

\section{Abstract}

We conducted constant rate of strain (CRS) consolidation tests on 16 whole-round samples obtained during Integrated Ocean Drilling Program (IODP) Expeditions 315 and 316 as part of Nankai Trough Seismogenic Zone Experiment (NanTroSEIZE) Stage 1 drilling. Samples were taken from slope sediments and the underlying accretionary wedge cored at IODP Sites C0001, C0004, and C0008 in the vicinity of a major out-of-sequence thrust fault (termed the megasplay). We conducted tests in parallel at the Rock and Sediment Mechanics Laboratory at The Pennsylvania State University (USA) and the geotechnical laboratory at the University of Missouri (USA), with the objectives of (1) defining the compression behavior and hydraulic properties of the sediments and (2) estimating in situ effective stress and pore pressure conditions from laboratory stress-strain behavior. In addition, we conducted quantitative fabric analyses at the University of Missouri on samples taken immediately adjacent to the CRS test specimens using an environmental scanning electron microscope. The samples exhibit similar consolidation and hydraulic properties. The samples exhibit a general trend of increasing fabric development with depth at Sites C0004 and C0008, with samples from the accretionary prism at Site C0001 and slope sediments in the footwall of the megasplay fault at Site C0004 exhibiting a higher degree of grain alignment. The compression index ranges from 0.419 to 1.058 for the entire suite of samples, with most values ranging from 0.6 to 0.8 . Intrinsic permeability decreases systematically with increasing effective axial stress and decreasing porosity and varies log-linearly with porosity. The permeability-porosity trends for specimens from the three sites are similar and exhibit no systematic variation with depth. Estimated values of in situ hydraulic conductivity follow a similar trend at all three sites and decrease with depth from values of $3.3 \times 10^{-10}$ to $1.0 \times 10^{-9} \mathrm{~m} / \mathrm{s}$ at $\sim 50$ meters below seafloor (mbsf) to $3.3 \times 10^{-11} \mathrm{~m} / \mathrm{s}$ at $440 \mathrm{mbsf}$. We estimated maximum preconsolidation stress $\left(P_{\mathrm{c}}{ }^{\prime}\right)$ using two separate techniques and consistently obtained values comparable to calculated values of hydrostatic vertical effective stress at Sites C0001 and C0008. Similarity of these values is consistent with normal consolidation and hydrostatic pore fluid pressures. In contrast, $P_{c}^{\prime}$ values for Site C0004 document apparent overconsolidation. 


\section{Introduction}

The Integrated Ocean Drilling Program (IODP) Nankai Trough Seismogenic Experiment (NanTroSEIZE) project is a multiexpedition, multiyear complex drilling project aimed at understanding the mechanics of subduction zone faulting and earthquakes through a combination of coring, logging, downhole measurements, and observatory installation, coupled with allied geophysical surveys and laboratory experimental studies (Tobin et al., 2009). As part of operations during NanTroSEIZE Stage 1, core samples were collected at several riserless drill sites for postexpedition laboratory study (Ashi et al., 2009; Screaton et al., 2009a). The compression behavior and hydrologic properties of marine sediments are particularly relevant to the objectives of the NanTroSEIZE project because they exert fundamental control on subseafloor fluid flow, consolidation and dewatering, and the potential generation of excess pore pressures in response to loading by rapid sedimentation and/or tectonic compression.

Here, we report on laboratory consolidation testing of samples collected at IODP Sites C0001, C0004, and C0008 in the vicinity of the "megasplay" fault, a major out-of-sequence thrust (OOST). The fault cuts the accretionary wedge and extends $>120 \mathrm{~km}$ along strike, and it has been implicated in coseismic slip (Fig. F1) (e.g., Park et al., 2002; Moore et al., 2007). Thus, the megasplay fault is a primary drilling target for the NanTroSEIZE program. Site C0001 sampled the hanging wall of the megasplay fault, and Site C0004 penetrated through the fault into the footwall, which consists of underthrust slope-apron deposits (Expedition 314 Scientists, 2009a, 2009b; Expedition 315 Scientists, 2009b; Expedition 316 Scientists, 2009a). Site C0008 sampled mildly disturbed slope-basin sediments resting above accreted trench-wedge deposits (Expedition 316 Scientists, 2009b). Figure F2 shows the stratigraphic and structural context of all sampling intervals, as well as the dip of bedding in close proximity to the samples.

We obtained 16 whole-round core samples from the drill sites and conducted constant rate of strain (CRS) consolidation tests in order to define (1) sediment compression behavior, (2) the maximum in situ effective normal stress $\left(P_{c}^{\prime}\right)$, and (3) sediment permeability and hydraulic conductivity. Here we report the results of 19 CRS tests, conducted on 16 wholeround core samples (and including three repeat experiments to assess experimental reproducibility) (Table T1). In addition, we conducted quantitative fabric analyses at the University of Missouri (USA) on samples taken immediately adjacent to the CRS test specimens using an environmental scanning electron microscope (ESEM) to image grain fabrics within horizontally and vertically oriented surfaces. Evaluation of microfabric images needs to take bedding dips into account, as shown in Figure F2. We combine results from tests conducted following the same experimental protocols at two institutions: the Rock and Sediment Mechanics Laboratory at The Pennsylvania State University (USA; herein referred to as PSU) and the geotechnical laboratory at the University of Missouri (MU). All notations for this report are summarized in Table T2; sample information and a summary of experimental results are shown in Table T3. Results from fabric analyses are shown in Table T1. Experimental data for each CRS test are provided in CRS in "Supplementary material."

\section{Experimental methods}

\section{Sample handling and preparation}

During the drilling expeditions, whole-round samples of $\sim 10-20 \mathrm{~cm}$ length were selected for postexpedition geotechnical tests using X-ray computed tomography (CT) scans to identify minimally disturbed intervals of hemipelagic mud/mudstone. Whole-round samples were sealed in plastic core liners using plastic caps and electrical tape, sealed within aluminum vacuum bags with wet sponges to minimize desiccation, and stored in a refrigerator until the end of the expedition. At that time, samples were shipped with cold packs by courier to the PSU and MU laboratories, where they were kept refrigerated until they were trimmed and used for CRS tests.

After removing whole-round samples from the core liner, we carefully trimmed cylindrical specimens to fit in the fixed steel ring of an oedometer system (Fig. F3) using a sharp stainless steel cutting shoe (to cut the specimen to the exact ring diameter) and a wire saw and trimming jig to attain flat top and bottom specimen faces. The specimen diameter for PSU tests was either $50 \mathrm{~mm}$ or $36.6 \mathrm{~mm}$, depending on the test, and the specimen diameter for MU tests was $41 \mathrm{~mm}$ (Table T3). The initial specimen height was $\sim 20 \mathrm{~mm}$ for PSU tests in most cases and $\sim 24 \mathrm{~mm}$ for MU tests. During specimen preparation, we took trimmings for measurement of water content and initial void ratio (ASTM International, 2006; Long et al., 2008). We determined specimen water content and void ratio from wet mass and dry mass after oven drying at $105^{\circ} \mathrm{C}$ for $24 \mathrm{~h}$, following the IODP method used for moisture and density (MAD) measurements that accounts for salt mass in seawater (Blum, 1997; Expedition 315 Scientists, 2009a). These values are reported in Table T3. In addition, we obtained a second measurement of index proper- 
ties after completion of the CRS test by oven drying the test specimen in the steel ring and using the same method.

After trimming, we placed specimens in the fixed ring of the oedometer system and deaired the system and pore fluid lines using a vacuum pump. We then backpressured the specimens to values of $u_{\mathrm{b}}=\sim 200$ $\mathrm{kPa}(\mathrm{MU})$ or $u_{\mathrm{b}}=\sim 300-400 \mathrm{kPa}$ (PSU) using deaired synthetic seawater for $24 \mathrm{~h}$ to ensure saturation and to dissolve any air remaining in the lines. To maintain contact between the loading ram and specimen and to prevent swelling during backpressuring, we held the axial load at a value $\sim 10-20 \mathrm{kPa}$ higher than the backpressure to maintain an effective axial stress $\left(\sigma_{\mathrm{a}}{ }^{\prime}\right)$ of $<25 \mathrm{kPa}$ for the PSU tests and specified the axial stress to maintain a condition of $0.2 \%$ axial strain for the MU tests.

\section{Consolidation test procedure and computations}

We conducted CRS tests at the two laboratories, following the protocols and test configuration specified by the American Society for Testing and Materials (ASTM) (ASTM International, 2006). In our CRS tests, we deformed the specimen at a constant rate of strain, controlled via a specified displacement rate boundary condition applied by a computer-controlled load frame (Fig. F3). The sample is confined in a steel ring to maintain a condition of zero lateral deformation (i.e., uniaxial strain), is undrained at its base, and is open to backpressure $\left(u_{\mathrm{b}}\right)$ at its top. During each experiment, we continuously monitored specimen height $(h)$, total axial stress $\left(\sigma_{\mathrm{a}}\right)$, and basal pore pressure $(u)$. Tests were run to peak axial stresses of $\sim 20 \mathrm{MPa}$ at $\mathrm{MU}$ and either $\sim 20$ or $\sim 40 \mathrm{MPa}$ at PSU. For each test, we chose the displacement rate (or strain rate) to maintain an anticipated ratio of basal excess pore pressure to a total axial stress $\left(\Delta u / \sigma_{a}\right)$ less than $\sim 0.10$. Strain rates for the tests are shown in Table T3. We recorded the loading phase for all tests and the unloading phase for a subset of the experiments; these results are shown in the stress-strain and stress-void ratio curves in Figures F4, F5, F6, F7, F8, F9, F10, F11, F12, F13, F14, F15, F16, F17, F18, F19, F20, F21, F22, F23, F24, F25, F26, F27, F28, F29, F30, F31, F32, F33, F34, F35, F36, F37, F38, F39, F40, F41, and F42.

We computed the axial strain $(\varepsilon)$, base excess pressure $(\Delta u)$, average effective axial stress within the specimen $\left(\sigma_{a}{ }^{\prime}\right)$, hydraulic conductivity $(K)$, intrinsic permeability $(k)$, coefficient of volume compressibility $\left(m_{\mathrm{v}}\right)$, and coefficient of consolidation $\left(C_{\mathrm{v}}\right)$ as follows (ASTM International, 2006; Long et al., 2008):

$$
\varepsilon=\Delta_{\mathrm{h}} / h_{0}
$$

where displacements are measured by a linear voltage differential transformer (LVDT) mounted at the top of the consolidation cell (Fig. F3) and are corrected to account for the compliance of the testing system. Equation 1 defines the natural axial strain $\left(\Delta_{\mathrm{h}} / h_{0}\right)$ of the specimen and is used for subsequent calculations; in Figures F4-F42 and in all supplementary tables we report the strain as a percentage.

$$
\begin{gathered}
\Delta u=u-u_{\mathrm{b}} . \\
\sigma_{\mathrm{a}}{ }^{\prime}=\left[\sigma_{\mathrm{a}}{ }^{\prime}-(2 / 3) \Delta u\right]-u_{\mathrm{b}} . \\
K=\left(\dot{\varepsilon} \times h \times h_{0} \times \gamma_{\mathrm{w}}\right) / 2 \Delta u . \\
k=K v / \gamma_{\mathrm{w}} . \\
m_{\mathrm{v}}=\Delta \varepsilon / \Delta \sigma_{\mathrm{a}}{ }^{\prime} . \\
C_{\mathrm{v}}=K /\left(m_{\mathrm{v}} \times \gamma_{\mathrm{w}}\right) .
\end{gathered}
$$

We computed the compression index $\left(C_{c}\right)$ from the change in specimen void ratio as a function of effective axial stress; this relationship is also shown graphically as the slope of the virgin compression curve (Fig. F4):

$$
C_{\mathrm{c}}=(\Delta e) / \Delta \log \left(\sigma_{\mathrm{a}}{ }^{\prime}\right),
$$

where $e$ is specimen void ratio (Table T2). As part of our data analysis, we determined the maximum preconsolidation stress $\left(P_{\mathrm{c}}{ }^{\prime}\right)$, which is taken to represent the in situ effective stress under conditions of monotonic and uniaxial vertical loading (e.g., Holtz and Kovacs, 1981). We conducted this analysis for all specimens obtained from slope sediments but do not report $P_{\mathrm{c}}^{\prime}$ values for sediments sampled from the interior of the thrust wedge at Site C0001 (i.e., the accretionary prism) because the assumption of uniaxial vertical loading is most likely violated there. To estimate $P_{c}^{\prime}$, we employed the Casagrande method (Fig. F4A) (Casagrande, 1936) and the work (strain energy density) method (Fig. F4B) (Becker et al., 1987). In the case of one-dimensional consolidation, the strain energy density (SED) is given by (Becker et al., 1987; Germaine and Germaine, 2009)

$$
\operatorname{SED}=\operatorname{int}\left(\sigma_{\mathrm{a}}{ }^{\prime} \times \delta \varepsilon\right) .
$$

We compare these values to the in situ vertical effective stress expected under conditions of uniaxial vertical burial and hydrostatic pore fluid pressure $\left(P_{\mathrm{o}}\right)$, computed by integrating bulk density values ob- 
tained from shipboard measurements from the seafloor downward. The overconsolidation ratio (OCR) is defined by $P_{\mathrm{c}}{ }^{\prime} / P_{\mathrm{o}}$; OCR $=1$ indicates normal consolidation, whereas OCR $<1$ indicates underconsolidation and OCR $>1$ indicates overconsolidation. It should be noted that estimates of $P_{c}^{\prime}$ are subject to considerable uncertainty because of sample disturbance, the effects of drastically differing timescales between natural sedimentation-driven compaction rates and those achieved in laboratory experiments, the effects of cementation on specimen yield stress (e.g., Holtz and Kovacs, 1981), and the effects of tectonic consolidation under stress regimes in which the maximum effective stress is not vertical.

\section{ESEM fabric analyses}

Samples for ESEM imaging of sediment fabric were taken shipboard from locations immediately adjacent to each whole-round core sample. We prepared samples for ESEM imaging following the general procedures described in Yue et al. (submitted), and scanned two mutually perpendicular faces for each sample, one horizontal and the other vertical. ESEM images for each of the two faces are provided in ESEM in "Supplementary material." The approach used for fabric quantification follows the graphic standard deviation (sorting) statistics of Folk and Ward (1957), as described by Yue et al. (submitted). After processing the digital scanning electron microscope image, we constructed cumulative frequency curves to show the orientation of apparent long axes for clasts oriented from $0^{\circ}$ to $180^{\circ}$ across imaging surfaces cut parallel and perpendicular to the core axis. The degree of clast orientation $(d)$ equals

$$
d=\left[\left(\phi_{84}-\phi_{16}\right) / 4\right]+\left[\left(\phi_{95}-\phi_{5}\right) / 6.6\right]
$$

where $\phi_{84}, \phi_{16}, \phi_{95}$, and $\phi_{5}$ represent graphical picks for the angles of clast orientation at the 84th, 16th, 95th, and 5th percentiles, respectively, on the cumulative frequency curve. This graphical statistic avoids the laborious calculations required by moment statistics (Chiou et al., 1991). In theory, the maximum value of $d$ is equal to $72.3^{\circ}$ (i.e., a case in which at least $16 \%$ particles are oriented at an angle of $0^{\circ}$ and infinitely close to $180^{\circ}$, respectively). We normalized each $d$ value to this maximum by calculating the index of orientation (i), as defined by the following formula:

$$
i=1-(d / 72.3)
$$

We also report fabric results using rose diagrams to illustrate the number of grains (apparent long axes) aligned within each $10^{\circ}$ orientation bin from $0^{\circ}$ to $180^{\circ}$ across the imaging surface. Interpretations of these results (e.g., differences between horizontal and vertical faces) need to take the dip of bedding into account, as shown in Figure F2. If the fabric of a sedimentary deposit shows strong preferred grain orientation relative to the core axis, then the degree of orientation (d) will be smaller, the slope of cumulative frequency curve will be steeper near the midpoint and more nonlinear, and the index of orientation (i) will be larger and closer to 1.

\section{Results \\ CRS test results}

Results for each experiment are shown in Figures F5F42 and in Table T3. In general, compression behavior (values of $C_{\mathrm{c}}$ and $P_{\mathrm{c}}{ }^{\prime}$ ) and hydraulic conductivity and permeability ( $K$ and $k$ ) are similar for sediments from the three drill sites, and the results are consistent between the two laboratories. Values of $C_{\mathrm{c}}$ range from 0.535 to 1.058 for samples from Site C0001, with most values ranging between $\sim 0.6$ and 0.8 (Table T3). Values of $C_{c}$ for specimens from Sites $\mathrm{C0004}$ and C0008 range from 0.624 to 0.768 and from 0.419 to 0.638 , respectively.

Experimental results also show that permeability varies strongly with effective stress and porosity. Permeability varies log-linearly with porosity and decreases from $1 \times 10^{-17}$ to $3 \times 10^{-16} \mathrm{~m}^{2}$ at porosities of $\sim 50 \%-$ $55 \%\left(\sigma_{a}^{\prime}\right.$ of $\sim 1-2 \mathrm{MPa}$ ) to $1.5 \times 10^{-19}$ to $\sim 6 \times 10^{-19} \mathrm{~m}^{2}$ at porosities of $23 \%-30 \%\left(\sigma_{a}{ }^{\prime}\right.$ of $40 \mathrm{MPa}$ ) (Fig. F43). Trends of decreasing permeability with increasing effective stress (Fig. F43A) and with progressive compaction (Fig. F43B) are similar for the slope apron and slope basin samples we tested from all three drill sites and exhibit no systematic variation with sample depth or site. The permeabilities of samples from the accretionary prism at Site C0001 are also similar to those of the slope sediments. Using the relationship between permeability and porosity for each specimen as shown in Figure F43B, we estimated the in situ hydraulic conductivity of each core sample from the in situ void ratio values shown in Table T3 (Fig. F44) (e.g., Long et al., 2008). Results indicate that in situ hydraulic conductivity deceases systematically with depth and follows a similar trend at all three sites, from values of $3.3 \times 10^{-10}$ to $1.0 \times 10^{-9} \mathrm{~m} / \mathrm{s}$ at $\sim 50$ mbsf to $3.3 \times 10^{-11} \mathrm{~m} / \mathrm{s}$ at $440 \mathrm{mbsf}$.

The Casagrande and SED approaches yield similar values of $P_{c}^{\prime}$ for our experiments (Table T3) and indicate normal consolidation (conditions of hydrostatic pore pressure and uniaxial strain) at Site C0001 to at least $\sim 140 \mathrm{mbsf}$ and at Site C0008 to at least $\sim 210$ mbsf (Fig. F45). This result is consistent with drilling 
results that did not document substantial evidence for significant fluid overpressure or fluid flow (Screaton et al., 2009b). In contrast, specimens from the footwall of the megasplay at Site C0004 (underthrust slope apron) exhibit significant overconsolidation (OCR values of $2.3-3.3$ ).

We also semiquantitatively assess sample quality and disturbance, which may be caused by drilling, sampling, and specimen handling. Disturbance generally results in a decrease in effective stress relative to the in situ effective stress and destructuring of the sediment fabric such that laboratory stress-strain response may not be representative of in situ behavior (e.g., Lunne et al., 1997; Germaine and Germaine, 2009). For each test, we report a Specimen Quality Designation (SQD) following Lunne et al. (1997), based on a measure of $\Delta e / \mathrm{e}_{\mathrm{i}}$ and OCR, where $\Delta e$ is the change in void ratio from the initial void ratio $e_{i}$ to the estimated in situ void ratio measured along a uniaxial consolidation path (Table T3). SQD generally ranges from $B$ (good to fair) to $C$ (poor) for shallow samples from Site C0001 ( $<200 \mathrm{mbsf})$. Deeper samples from Site C0001 and those from Sites C0004 and $\mathrm{C0008}$ are generally rated D (very poor). Despite the fact that the relationships between void ratio and effective stress from CRS tests generally show characteristics of higher quality samples (e.g., well defined yield stress), the potential consequences of sample disturbance in interpretation of these results should be appreciated.

\section{Fabric results}

Table T1 summarizes the results of our ESEM fabric analysis. Figures F46, F47, and F48 show rose diagrams of the grain orientations (apparent long axes) imaged across horizontal and vertical faces relative to the core axis. The corresponding cumulative orientation curves are shown in Figures F49, F50, and F51. Average values for the orientation index of samples from the three sites range from $\sim 0.30-0.32$, and we see a general trend of fabric development increasing with depth at Sites C0004 and C0008, particularly in vertical sections (Table T1; Figs. F46, F47, F48). In comparison, samples from the accretionary prism at Site C0001 and slope sediments in the footwall of the megasplay fault at Site C0004 exhibit higher values for the orientation index $(>0.40)$ (Table T1; Figs. F49, F50), indicating a higher alignment of grains.

\section{Acknowledgments}

This research used samples provided by the Integrated Ocean Drilling Program (IODP) and wholeround samples that were carefully selected and stored through the efforts of shipboard scientists during Expeditions 315 and 316 and the Marine Works Japan shipboard laboratory technicians. This research was supported by postexpedition awards from the Consortium for Ocean Leadership to $\mathrm{MBU}$ (T315B58 and T315C58) and WL and by National Science Foundation Expedition Objective Research (EOR) awards OCE-0752114 (to PSU) and OCE0751819 (to MU). Burns and McDonnell provided a generous contribution toward acquisition of the CRS system at the University of Missouri, and Lou Ross provided guidance on ESEM imaging. We thank Brandon Dugan and Elizabeth Screaton for helpful comments that have improved the presentation and clarity of this report.

\section{References}

Ashi, J., Lallemant, S., Masago, H., and the Expedition 315 Scientists, 2009. Expedition 315 summary. In Kinoshita, M., Tobin, H., Ashi, J., Kimura, G., Lallemant, S., Screaton, E.J., Curewitz, D., Masago, H., Moe, K.T., and the Expedition 314/315/316 Scientists, Proc. IODP, 314/315/ 316: Washington, DC (Integrated Ocean Drilling Program Management International, Inc.). doi:10.2204/ iodp.proc.314315316.121.2009

ASTM International, 2006. Standard test methods for specific gravity of soil solids by water pycnometer (D85406). In Annual Book of ASTM Standards (Vol 04.08): Soil and Rock (I): West Conshohocken, PA (Am. Soc. Testing Mater.).

Becker, D.E., Crooks, J.H.A., Been, K., and Jeffries, M.G., 1987. Work as a criterion for determining in situ and yield stresses in clays. Can. Geotech. J., 24(4):549-564. doi:10.1139/t87-070

Blum, P., 1997. Physical properties handbook: a guide to the shipboard measurement of physical properties of deep-sea cores. ODP Tech. Note, 26. doi:10.2973/ odp.tn.26.1997

Casagrande, A., 1936. The determination of pre-consolidation load and its practical significance. In Casagrande, A., Rutledge, P.C., and Watson, J.D. (Eds.), Proc. 1st Int. Conf. Soil Mech. Found. Eng. Am. Soc. Civ. Eng., 3:60-64.

Chiou, W.A., Bryant, W.R., and Bennett, R.H., 1991. Quantification of clay fabric: a simple technique. In Bennett, R.H., Bryant, W.R., and Hulbert, M.H. (Eds.), Microstructure of Fine-Grained Sediments: From Mud to Shale: New York (Springer-Verlag), 379-387.

Expedition 314 Scientists, 2009a. Expedition 314 Site C0001. In Kinoshita, M., Tobin, H., Ashi, J., Kimura, G., Lallemant, S., Screaton, E.J., Curewitz, D., Masago, H., Moe, K.T., and the Expedition 314/315/316 Scientists, Proc. IODP, 314/315/316: Washington, DC (Integrated Ocean Drilling Program Management International, Inc.). doi:10.2204/iodp.proc.314315316.113.2009

Expedition 314 Scientists, 2009b. Expedition 314 Site C0004. In Kinoshita, M., Tobin, H., Ashi, J., Kimura, G., Lallemant, S., Screaton, E.J., Curewitz, D., Masago, H., 
Moe, K.T., and the Expedition 314/315/316 Scientists, Proc. IODP, 314/315/316: Washington, DC (Integrated Ocean Drilling Program Management International, Inc.). doi:10.2204/iodp.proc.314315316.116.2009

Expedition 315 Scientists, 2009a. Expedition 315 methods. In Kinoshita, M., Tobin, H., Ashi, J., Kimura, G., Lallemant, S., Screaton, E.J., Curewitz, D., Masago, H., Moe, K.T., and the Expedition 314/315/316 Scientists, Proc. IODP, 314/315/316: Washington, DC (Integrated Ocean Drilling Program Management International, Inc.). doi:10.2204/iodp.proc.314315316.123.2009

Expedition 315 Scientists, 2009b. Expedition 315 Site C0001. In Kinoshita, M., Tobin, H., Ashi, J., Kimura, G., Lallemant, S., Screaton, E.J., Curewitz, D., Masago, H., Moe, K.T., and the Expedition 314/315/316 Scientists, Proc. IODP, 314/315/316: Washington, DC (Integrated Ocean Drilling Program Management International, Inc.). doi:10.2204/iodp.proc.314315316.123.2009

Expedition 316 Scientists, 2009a. Expedition 316 Site C0004. In Kinoshita, M., Tobin, H., Ashi, J., Kimura, G., Lallemant, S., Screaton, E.J., Curewitz, D., Masago, H., Moe, K.T., and the Expedition 314/315/316 Scientists, Proc. IODP, 314/315/316: Washington, DC (Integrated Ocean Drilling Program Management International, Inc.). doi:10.2204/iodp.proc.314315316.133.2009

Expedition 316 Scientists, 2009b. Expedition 316 Site C0008. In Kinoshita, M., Tobin, H., Ashi, J., Kimura, G., Lallemant, S., Screaton, E.J., Curewitz, D., Masago, H., Moe, K.T., and the Expedition 314/315/316 Scientists, Proc. IODP, 314/315/316: Washington, DC (Integrated Ocean Drilling Program Management International, Inc.). doi:10.2204/iodp.proc.314315316.136.2009

Folk, R.L., and Ward, W.C., 1957. Brazos River bar [Texas]: a study in the significance of grain size parameters. $J$. Sediment. Res., 27(1):3-26. http://jsedres.sepmonline.org/cgi/content/abstract/27/1/3

Germaine, J.T., and Germaine, A.V., 2009. Geotechnical Laboratory Measurements for Engineers: Hoboken, NJ (Wiley).

Holtz, R.D., and Kovacs, W.D., 1981. An Introduction to Geotechnical Engineering: Englewood Cliffs, NJ (Prentice-Hall).

Long, H., Flemings, P.B., Germaine, J.T., Saffer, D.M., and Dugan, B., 2008. Data report: consolidation characteristics of sediments from IODP Expedition 308, Ursa Basin, Gulf of Mexico. In Flemings, P.B., Behrmann, J.H., John, C.M., and the Expedition 308 Scientists, Proc. IODP, 308: College Station, TX (Integrated Ocean Drilling Program Management International, Inc.). doi:10.2204/ iodp.proc.308.204.2008

Lunne, T., Berre, T., and Strandvik, S., 1997. Sample disturbance effects in soft low plastic Norwegian clay. Publ.Nor. Geotek. Inst., 204:81-102.
Moore, G.F., Bangs, N.L., Taira, A., Kuramoto, S., Pangborn, E., and Tobin, H.J., 2007. Three-dimensional splay fault geometry and implications for tsunami generation. Science, 318(5853):1128-1131. doi:10.1126/science. 1147195

Park, J.-O., Tsuru, T., Kodaira, S., Cummins, P.R., and Kaneda, Y., 2002. Splay fault branching along the Nankai subduction zone. Science, 297(5584):1157-1160. doi:10.1126/science.1074111

Screaton, E.J., Kimura, G., Curewitz, D., and the Expedition 316 Scientists, 2009a. Expedition 316 summary. In Kinoshita, M., Tobin, H., Ashi, J., Kimura, G., Lallemant, S., Screaton, E.J., Curewitz, D., Masago, H., Moe, K.T., and the Expedition 314/315/316 Scientists, Proc. IODP, 314/315/316: Washington, DC (Integrated Ocean Drilling Program Management International, Inc.). doi:10.2204/iodp.proc.314315316.131.2009

Screaton, E., Kimura, G., Curewitz, D., Moore, G., Fabbri, O., Fergusson, C., Girault, F., Goldsby, D., Harris, R., Inagaki, F., Jiang, T., Kitamura, Y., Knuth, M., Li, C.-F., Claesson Liljedahl, L., Louis, L., Milliken, K., Nicholson, U., Riedinger, N., Sakaguchi, A., Solomon, E., Strasser, M., Su, X., Tsutsumi, A., Yamaguchi, A., Ujiee, K., and Zhao, X., 2009b. Interactions between deformation and fluids in the frontal thrust region of the NanTroSEIZE transect offshore the Kii Peninsula, Japan: results from IODP Expedition 316 Sites C0006 and C0007. Geochem., Geophys., Geosyst., 10:Q0AD01-Q0AD14. doi:10.1029/ 2009GC002713

Tobin, H., Kinoshita, M., Moe, K.T., and the Expedition 314 Scientists, 2009. Expedition 314 summary. In Kinoshita, M., Tobin, H., Ashi, J., Kimura, G., Lallemant, S., Screaton, E.J., Curewitz, D., Masago, H., Moe, K.T., and the Expedition 314/315/316 Scientists, Proc. IODP, 314/315/316: Washington, DC (Integrated Ocean Drilling Program Management International, Inc.). doi:10.2204/iodp.proc.314315316.111.2009

Yue, L., Likos, W.J., Guo, J., and Underwood, M.B., submitted. Data report: permeability of mud(stone) samples from Site C0001, IODP Expedition 315, Nankai Trough: Stage 1 of NanTroSEIZE. In Kinoshita, M., Tobin, H., Ashi, J., Kimura, G., Lallemant, S., Screaton, E.J., Curewitz, D., Masago, H., Moe, K.T., and the Expedition 314/ 315/316 Scientists, Proc. IODP, 314/315/316: Washington, DC (Integrated Ocean Drilling Program Management International, Inc.).

Initial receipt: 27 January 2011

Acceptance: 15 April 2011

Publication: 2 August 2011

MS 314315316-218 
Figure F1. A. Map showing location of study area and boreholes (after Kinoshita et al., 2008, and Moore et al., 2009). (Continued on next page.)

A

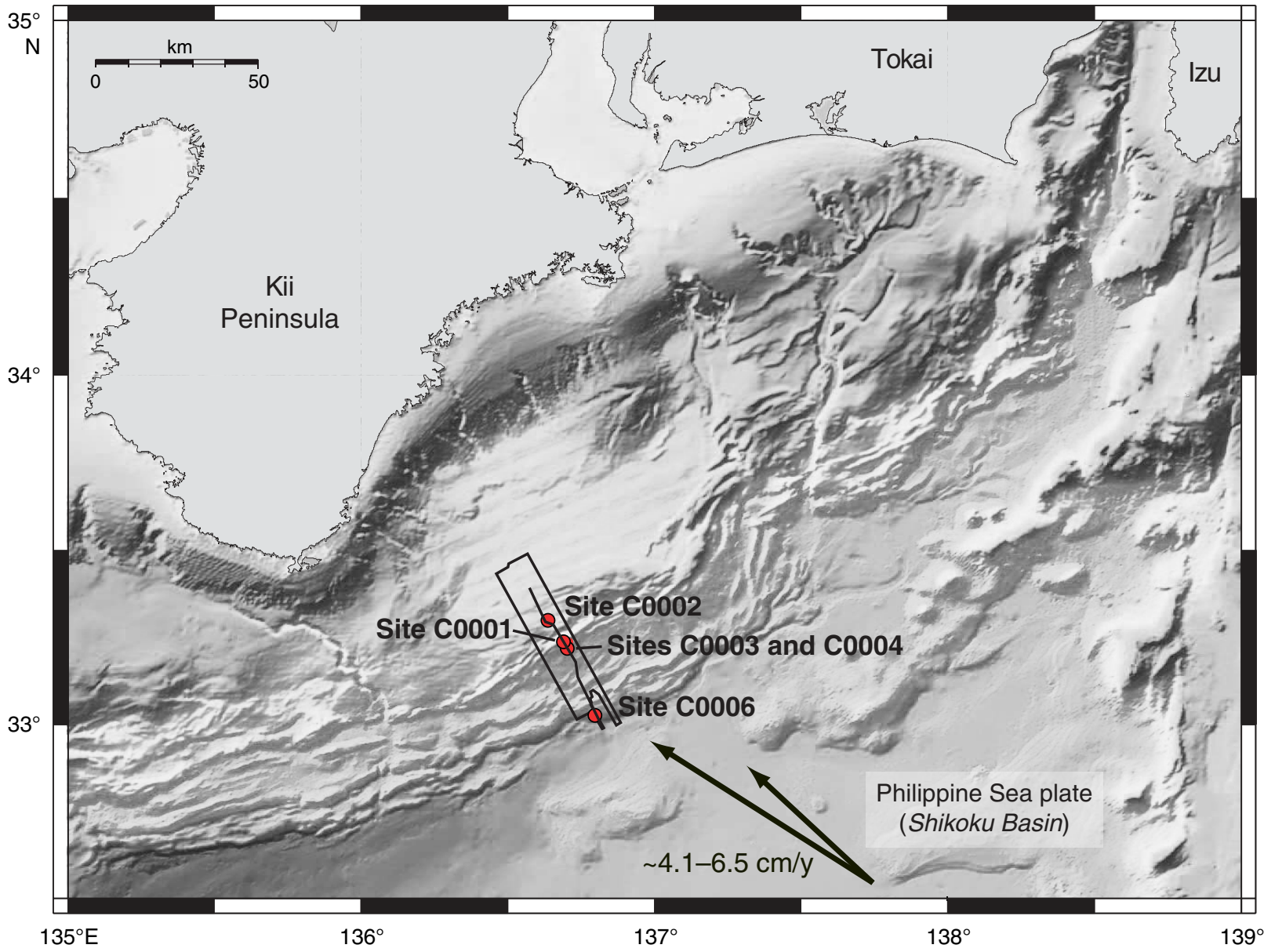


Figure F1 (continued). B. Regional composite seismic line that crosses boreholes (location shown in A). C, D. Detailed seismic sections showing Sites C0001, C0004, and C0008. VE = vertical exaggeration. $n=$ number of specimens from each drill site used in this study. (All parts after Moore et al., 2009.)
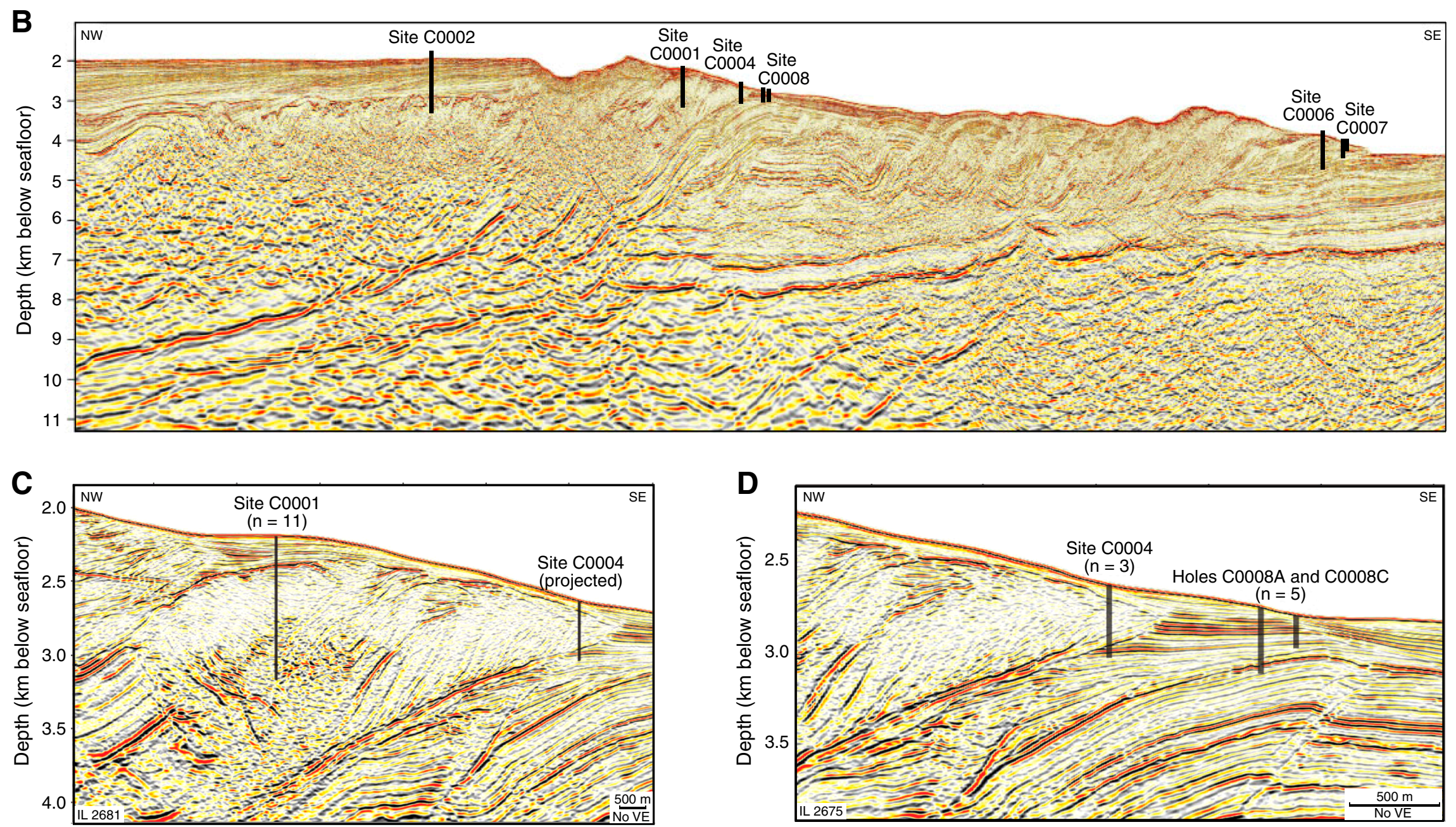
Figure F2. Stratigraphic summaries of Sites C0001, C0004, and C0008, showing sample locations annotated with bedding dips measured during shipboard core description.

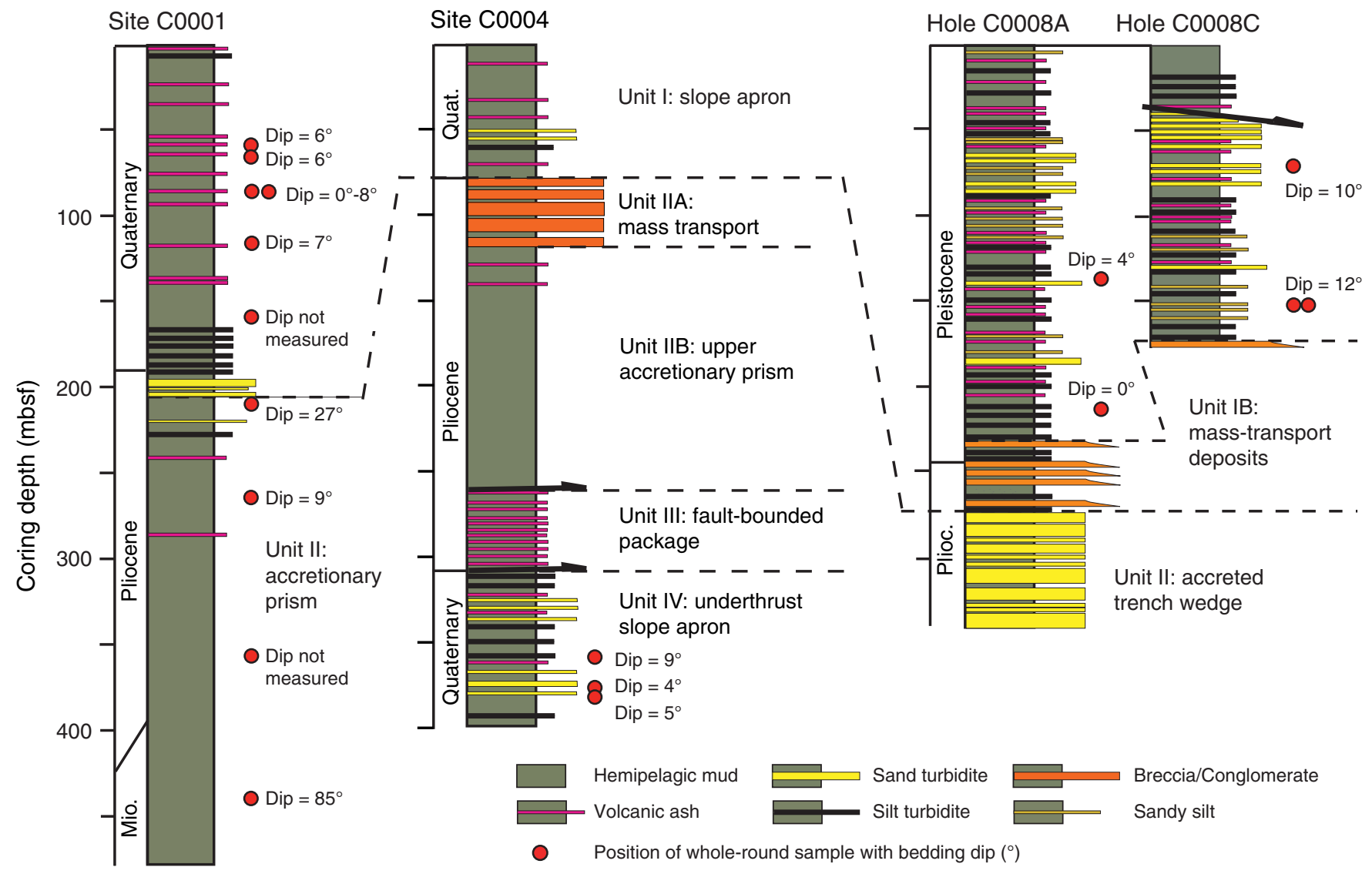


Figure F3. Schematic diagram of high-stress uniaxial consolidation system (oedometer) at PSU. LVDT = linear voltage differential transformer.

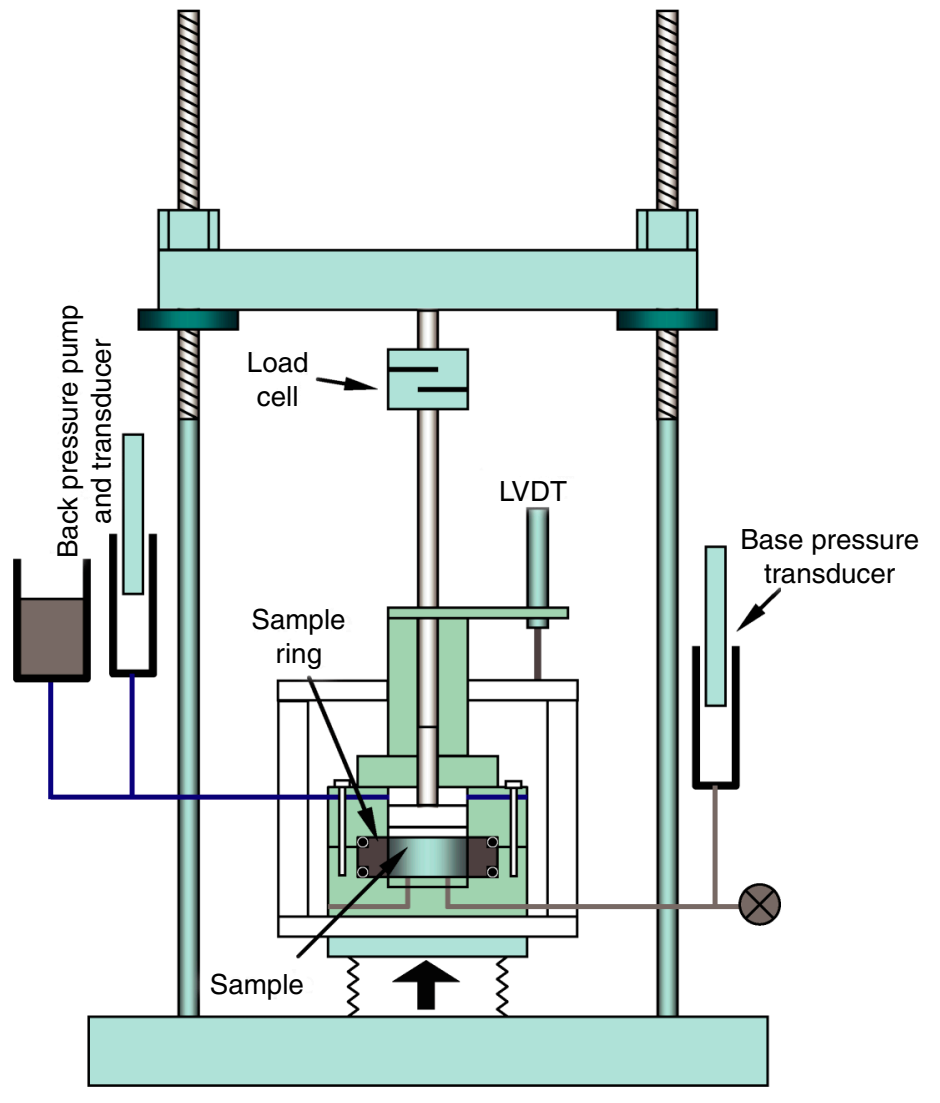


Figure F4. A. Example of void ratio-effective axial stress curve showing determination of $P_{c}^{\prime}$ following the Casagrande approach (Casagrande, 1936). Using this method, a line (segment B) is drawn tangent to the data at the point of maximum curvature. A line of constant void ratio is drawn from the same point (segment A), and the most likely preconsolidation stress $\left(P_{c}^{\prime}\right)$ is given by the intersection of a line that bisects the angle between the two (segment $\mathrm{C}$ ) and the virgin compression curve. We estimate the in situ void ratio as the void ratio at $P_{\mathrm{c}}{ }^{\prime}$ (Table T3). The slope of the virgin compression curve defines the compression index $\left(C_{c}\right)$ (see Equation 8 in text). B. Example of strain energy density-effective axial stress plot, showing the work-stress method for estimating $P_{c}^{\prime}$ (Becker et al., 1987). In this method, line segments are fit to the early part of the data and to the data during virgin compression, and $P_{c}^{\prime}$ is defined by their intersection. SED = strain energy density.
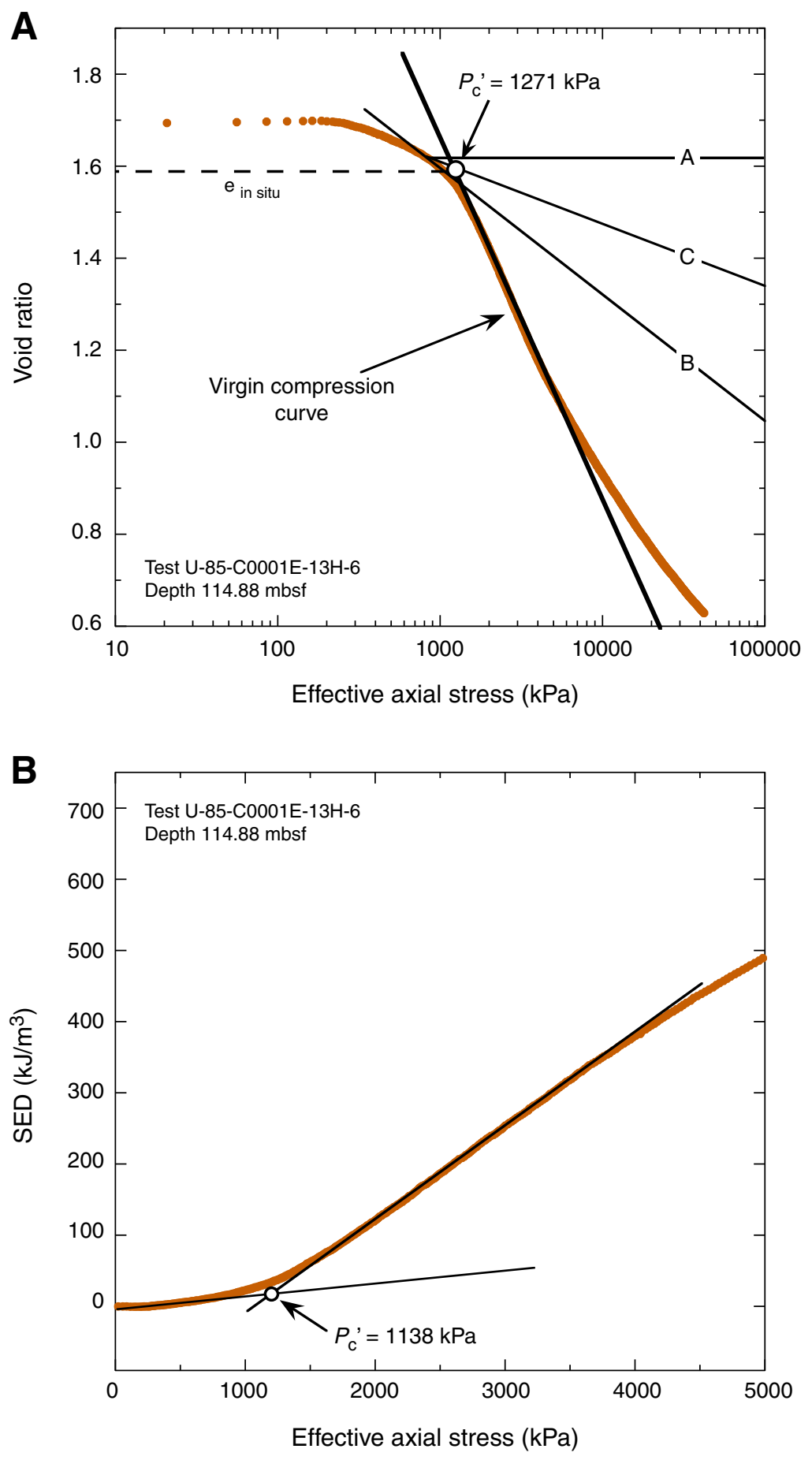
Figure F5. Time series data of effective axial stress $\left(\sigma_{a}{ }^{\prime}\right)$ and basal excess pore pressure $(\Delta u)$ for PSU test U-68 on Sample C0001E-7H-7.

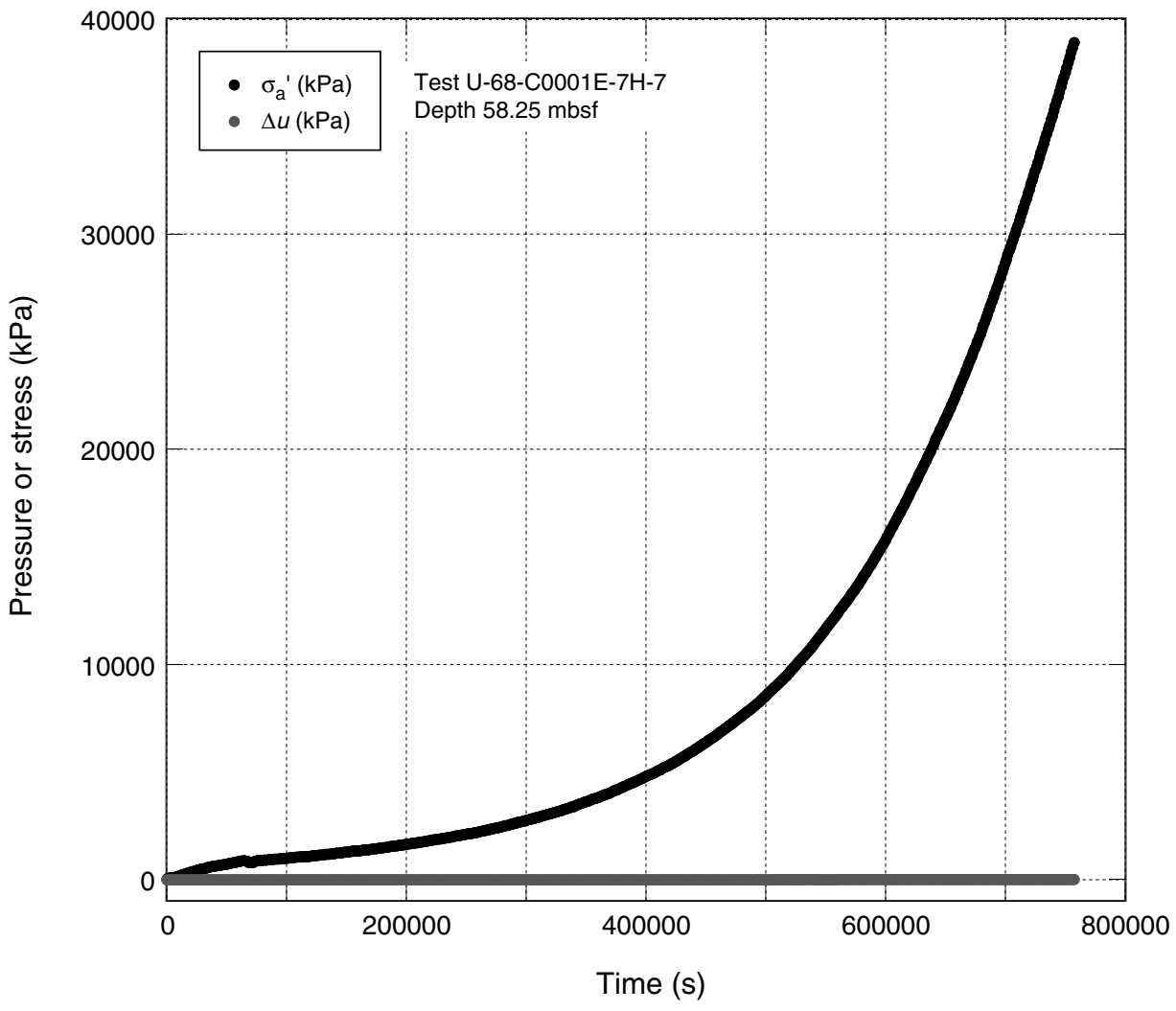



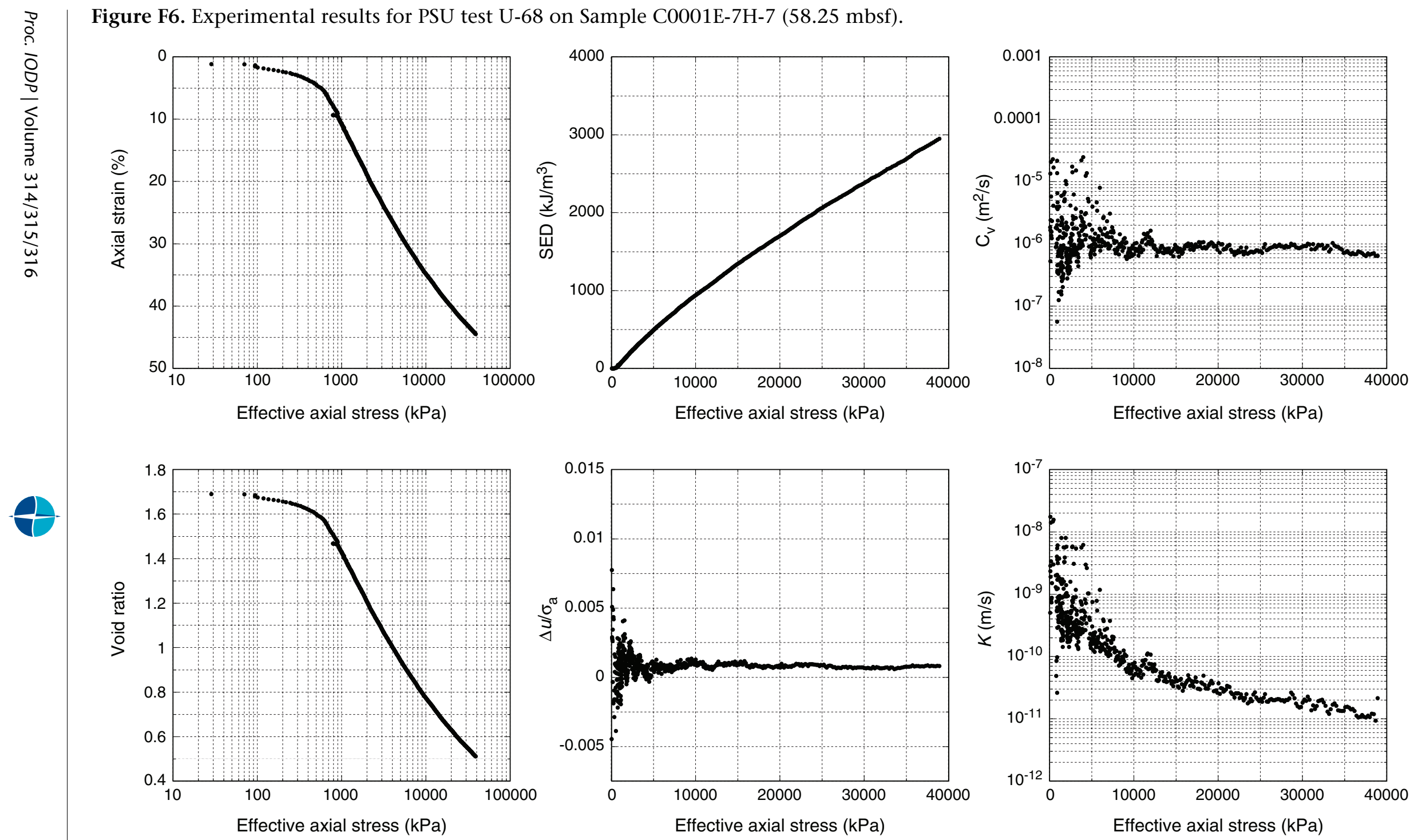
Figure F7. Time series data of effective axial stress $\left(\sigma_{a}{ }^{\prime}\right)$ and basal excess pore pressure $(\Delta u)$ for MU test on Sample C0001E-8H-3.

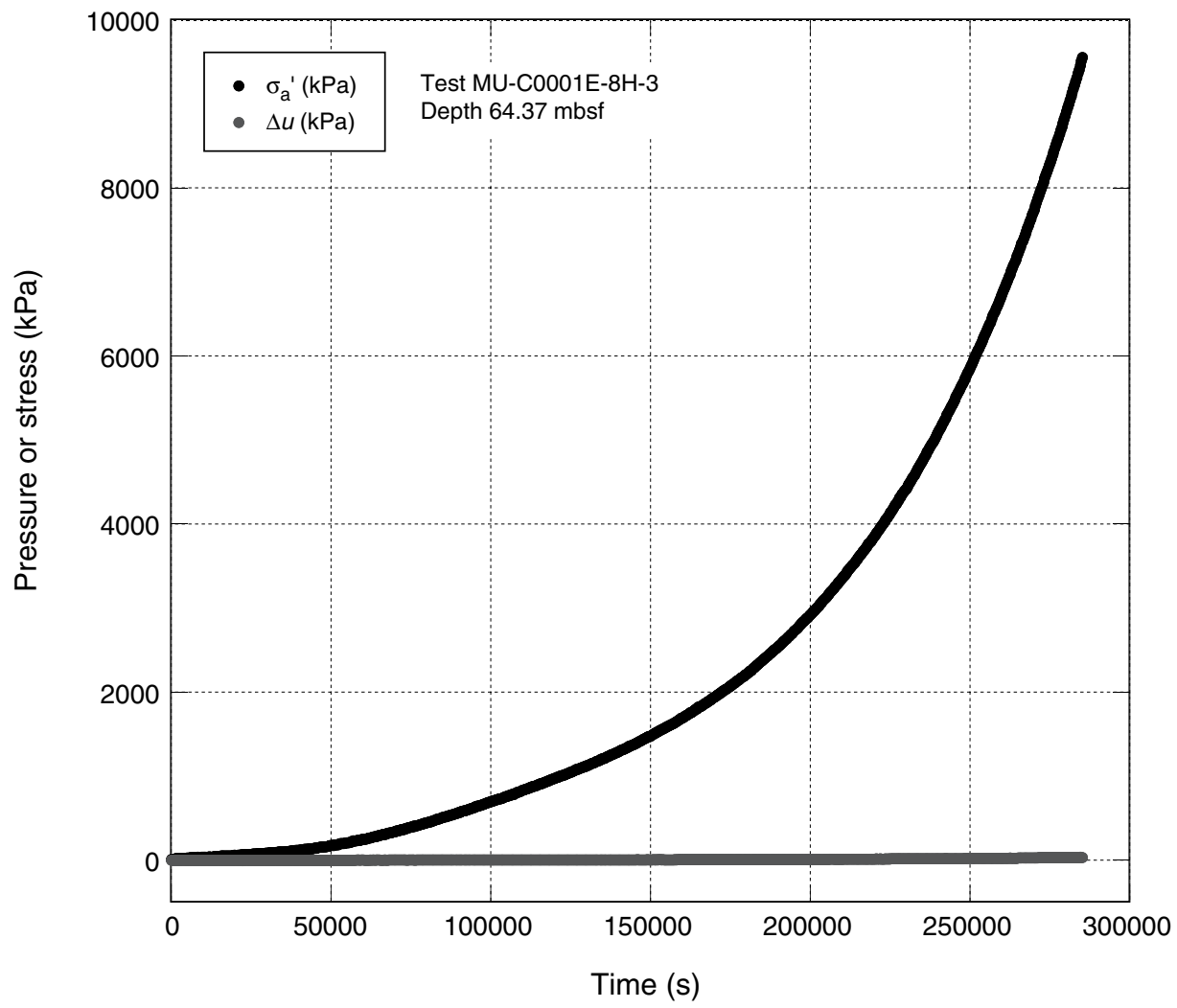



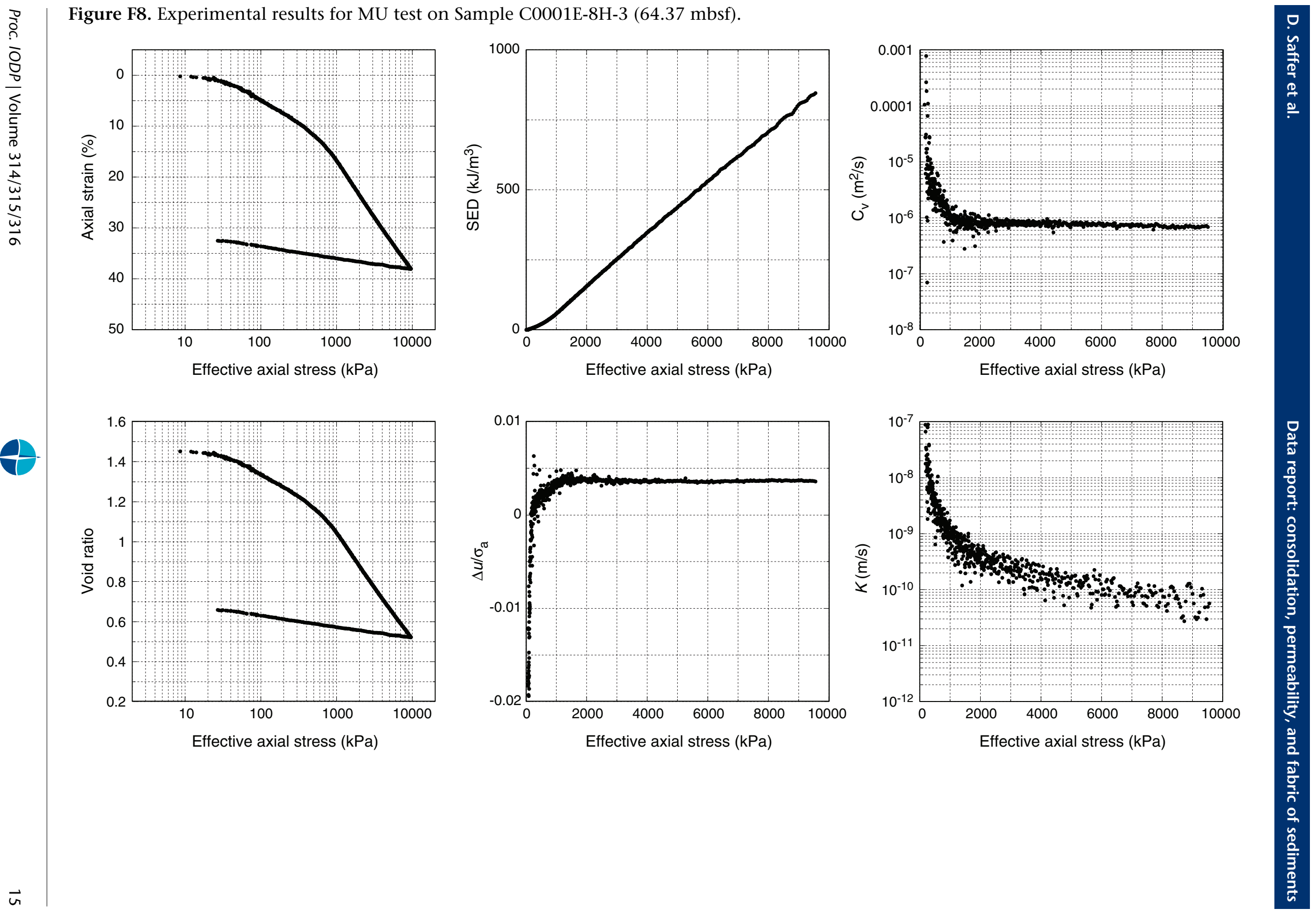
Figure F9. Time series data of effective axial stress $\left(\sigma_{a}{ }^{\prime}\right)$ and basal excess pore pressure $(\Delta u)$ for PSU test U-71 on Sample C0001E-10H-5.

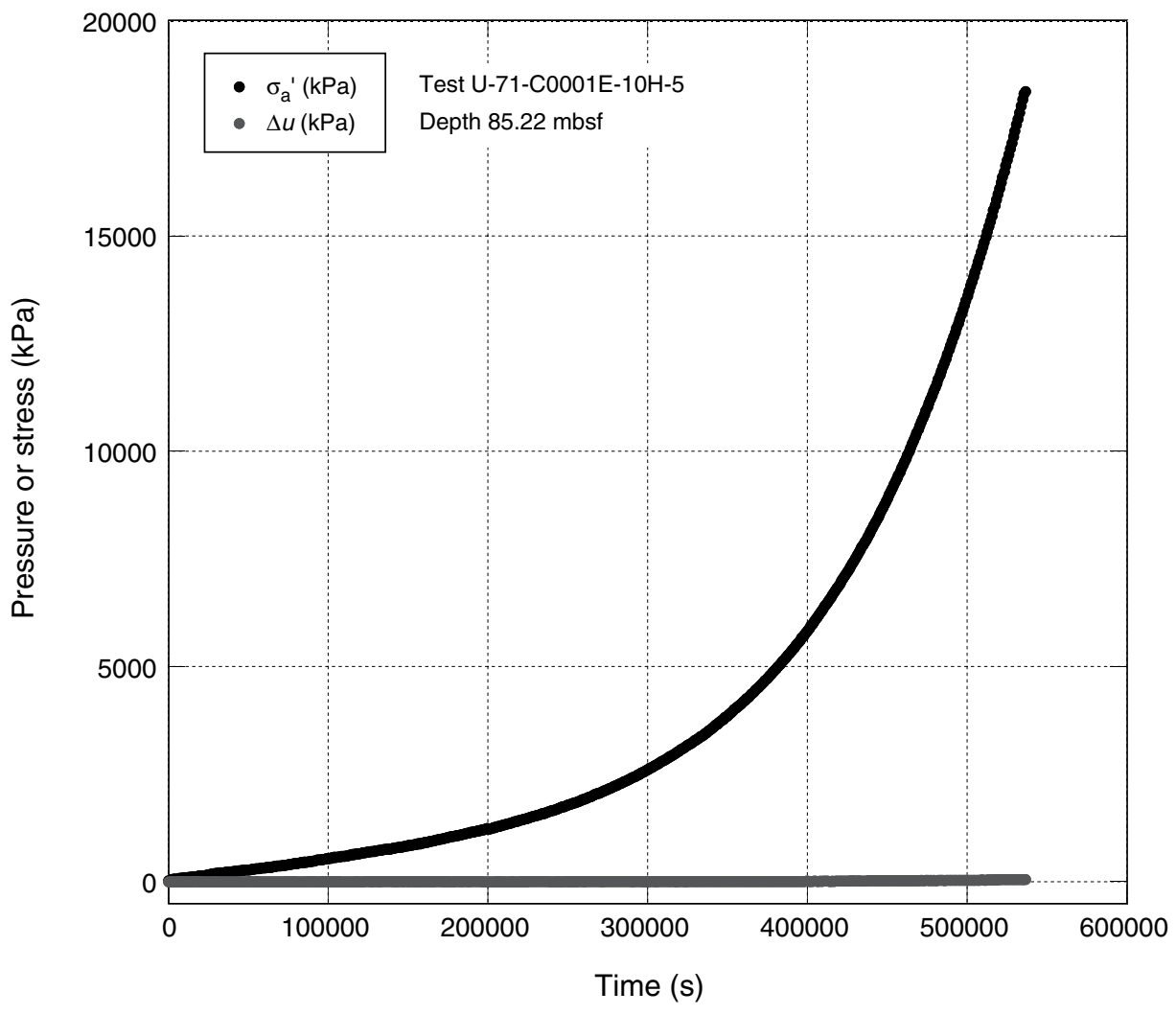



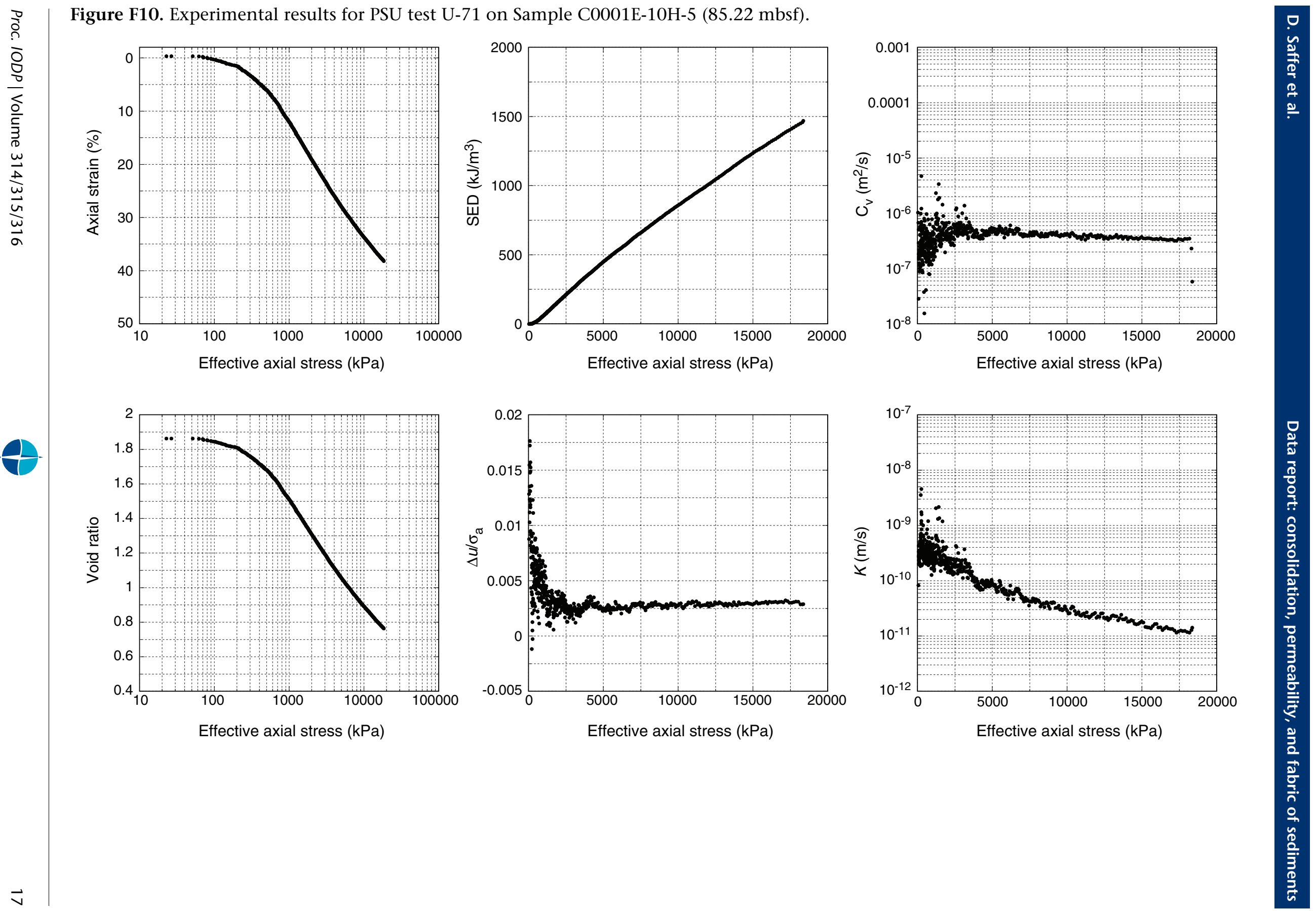
Figure F11. Time series data of effective axial stress $\left(\sigma_{a}{ }^{\prime}\right)$ and basal excess pore pressure $(\Delta u)$ for PSU test U-88 on Sample C0001E-10H-5.

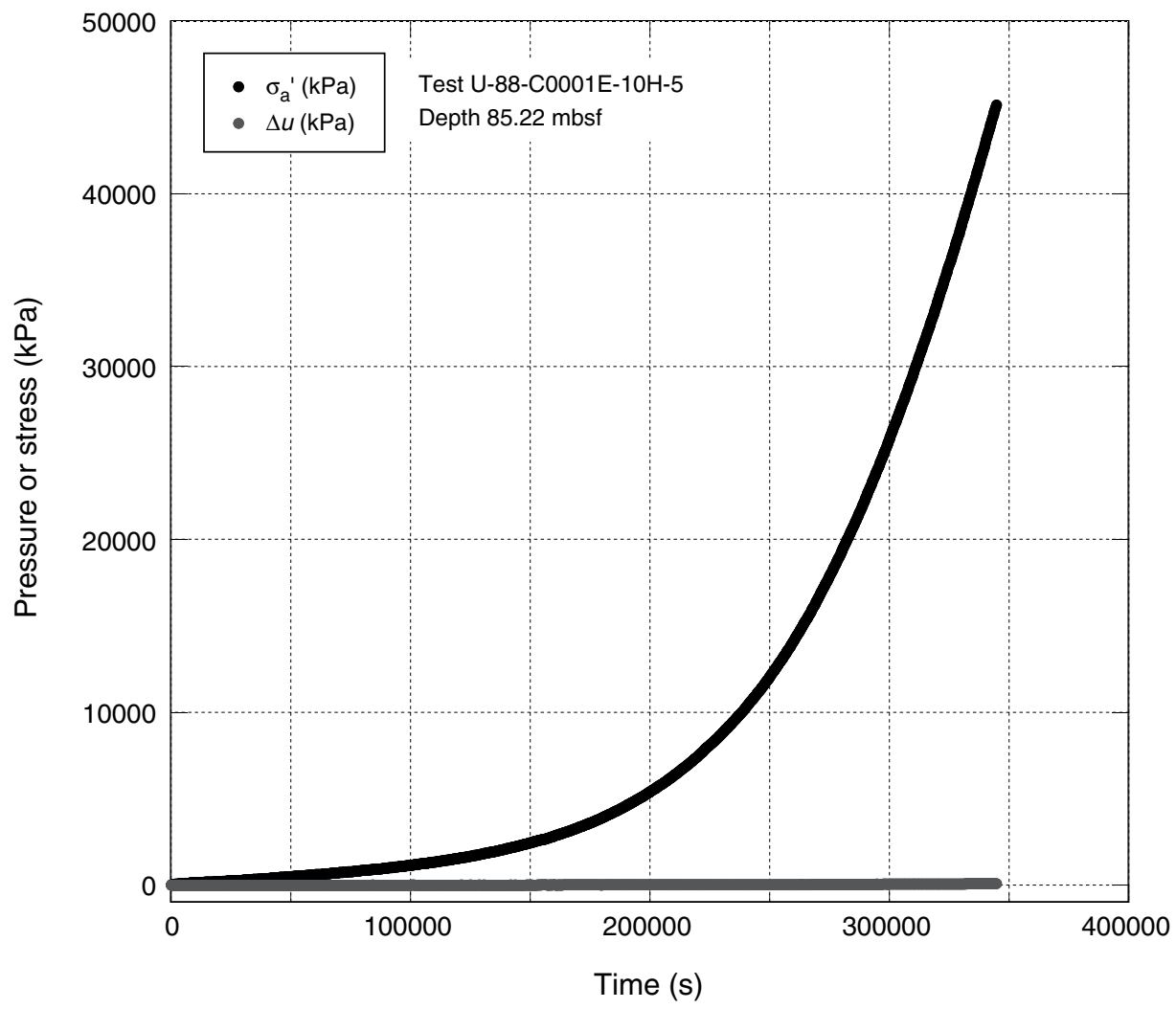



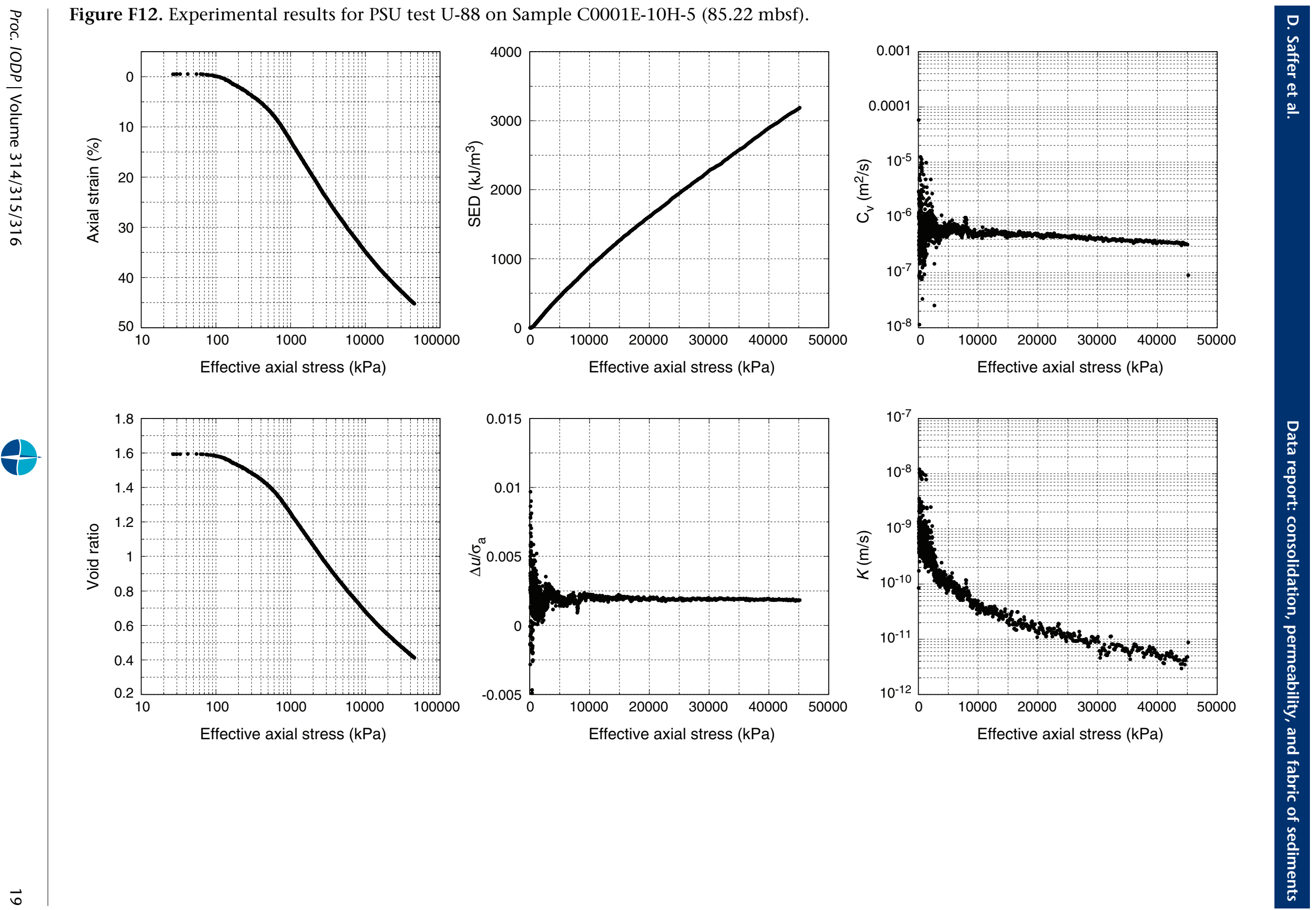
Figure F13. Time series data of effective axial stress $\left(\sigma_{a}{ }^{\prime}\right)$ and basal excess pore pressure $(\Delta u)$ for PSU test U-85 on Sample C0001E-13H-6.

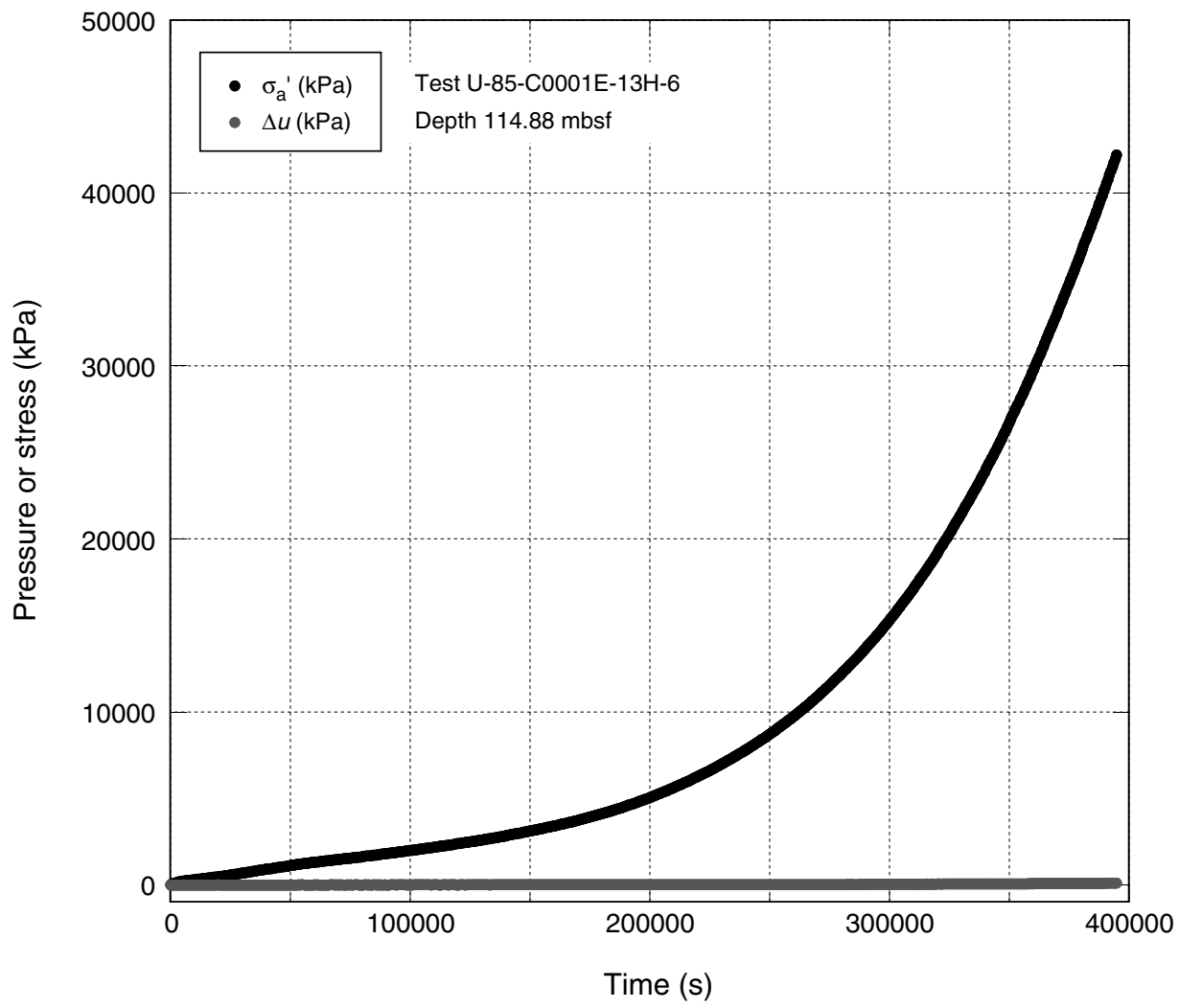


Figure F14. Experimental results for PSU test U-85 on Sample C0001E-13H-6 (114.88 mbsf).
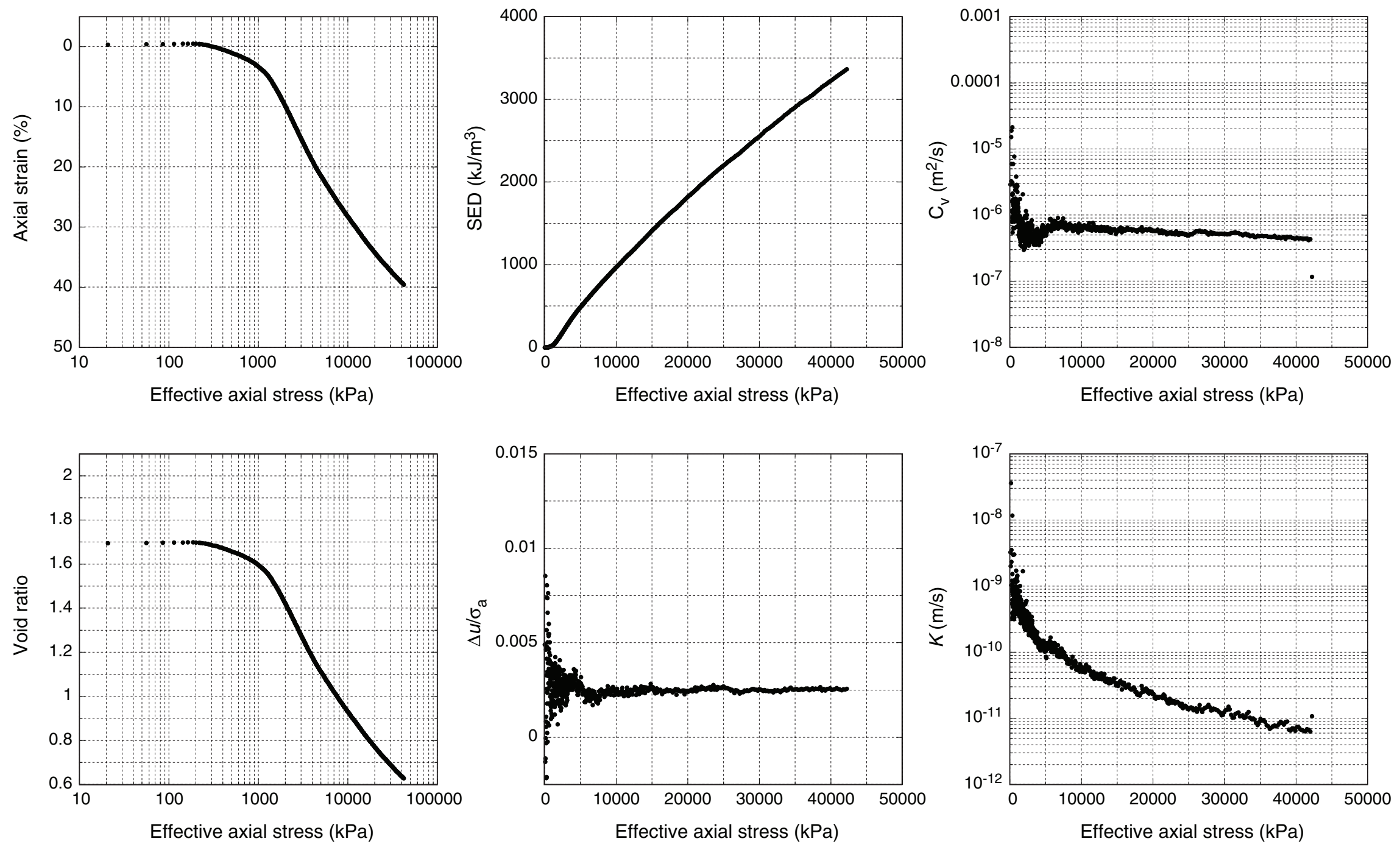
Figure F15. Time series data of effective axial stress $\left(\sigma_{a}{ }^{\prime}\right)$ and basal excess pore pressure $(\Delta u)$ for PSU test U-81 on Sample C0001E-13H-6.

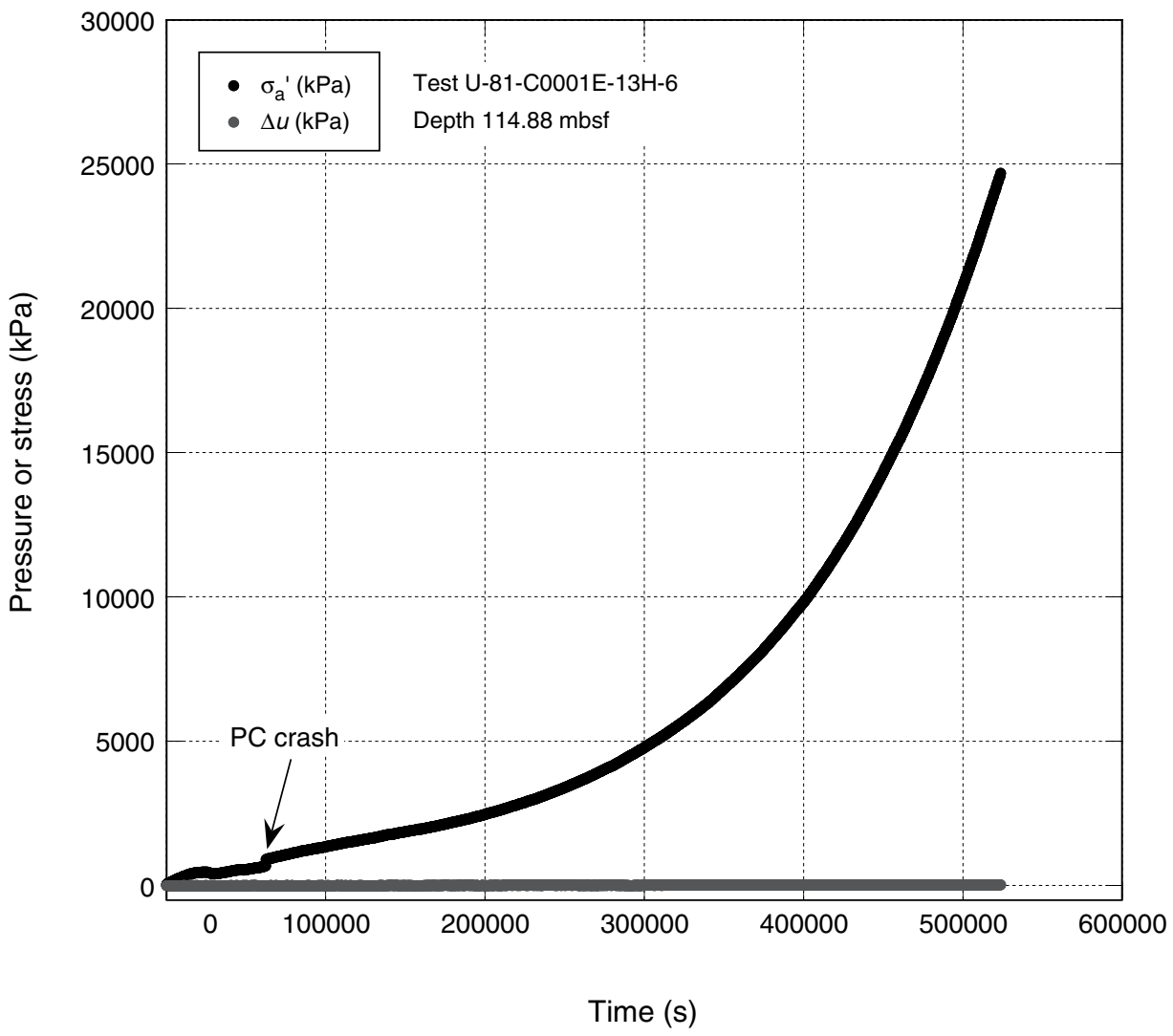



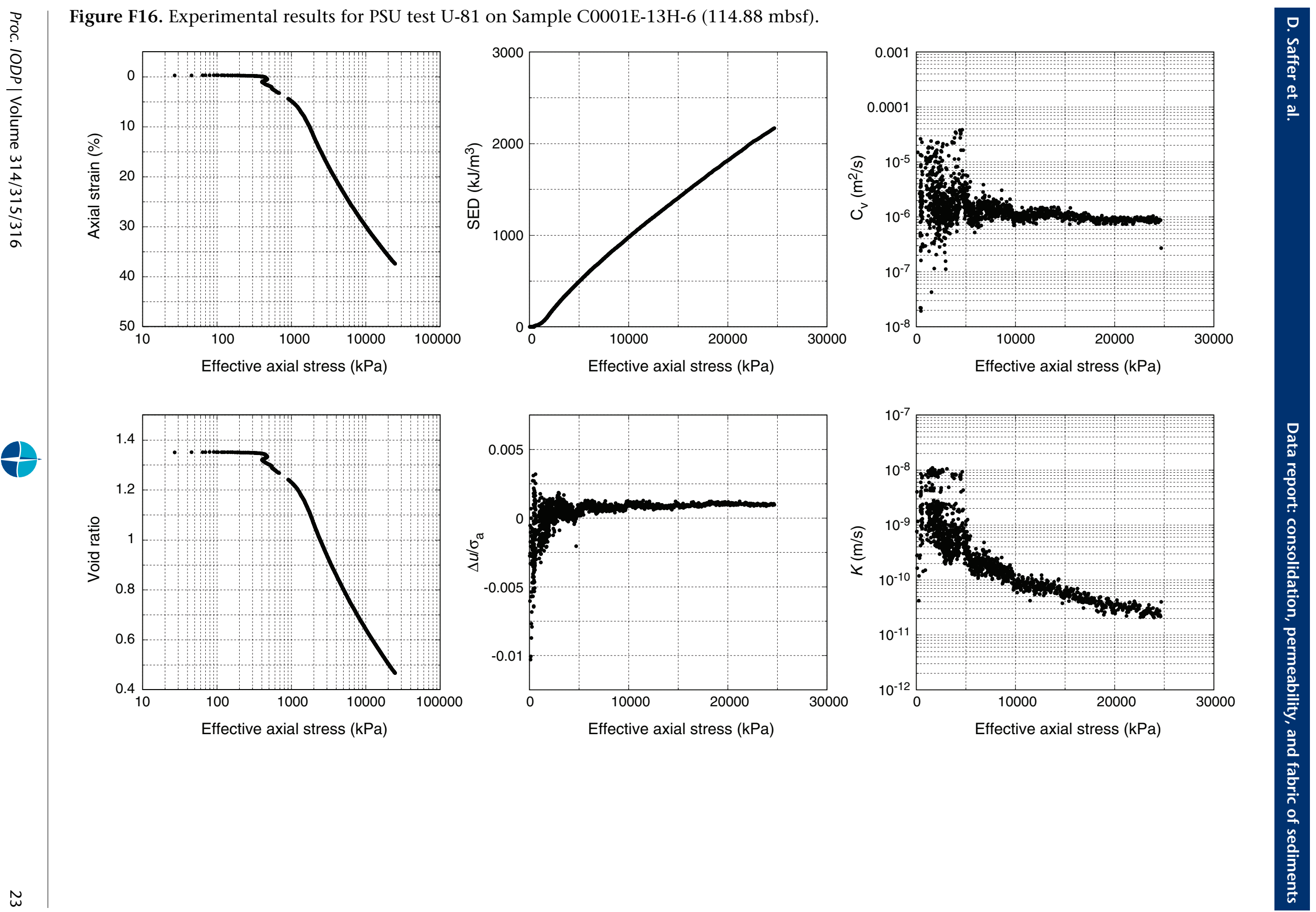
Figure F17. Time series data of effective axial stress $\left(\sigma_{a}{ }^{\prime}\right)$ and basal excess pore pressure $(\Delta u)$ for MU test on Sample C0001F-6H-5.

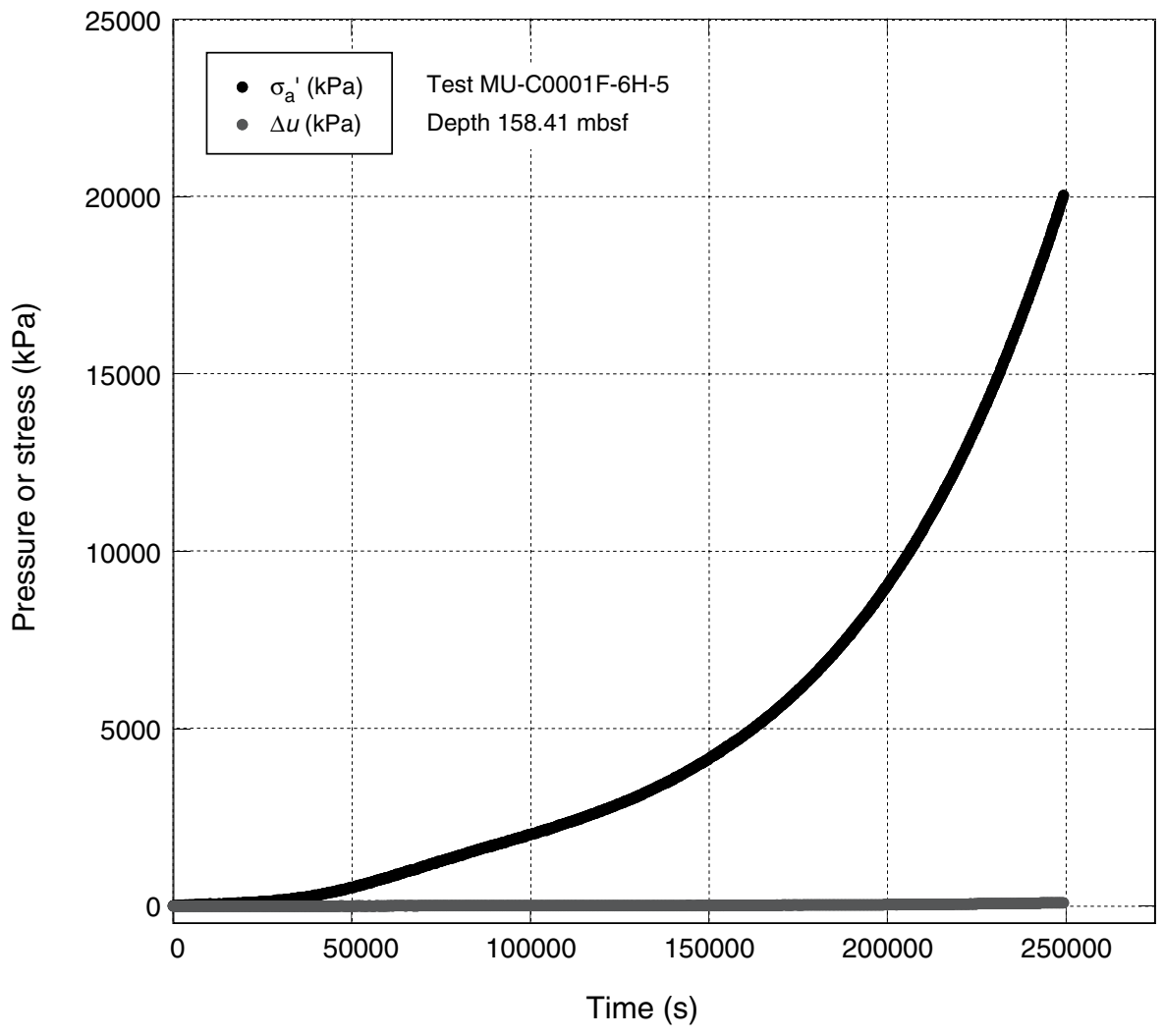



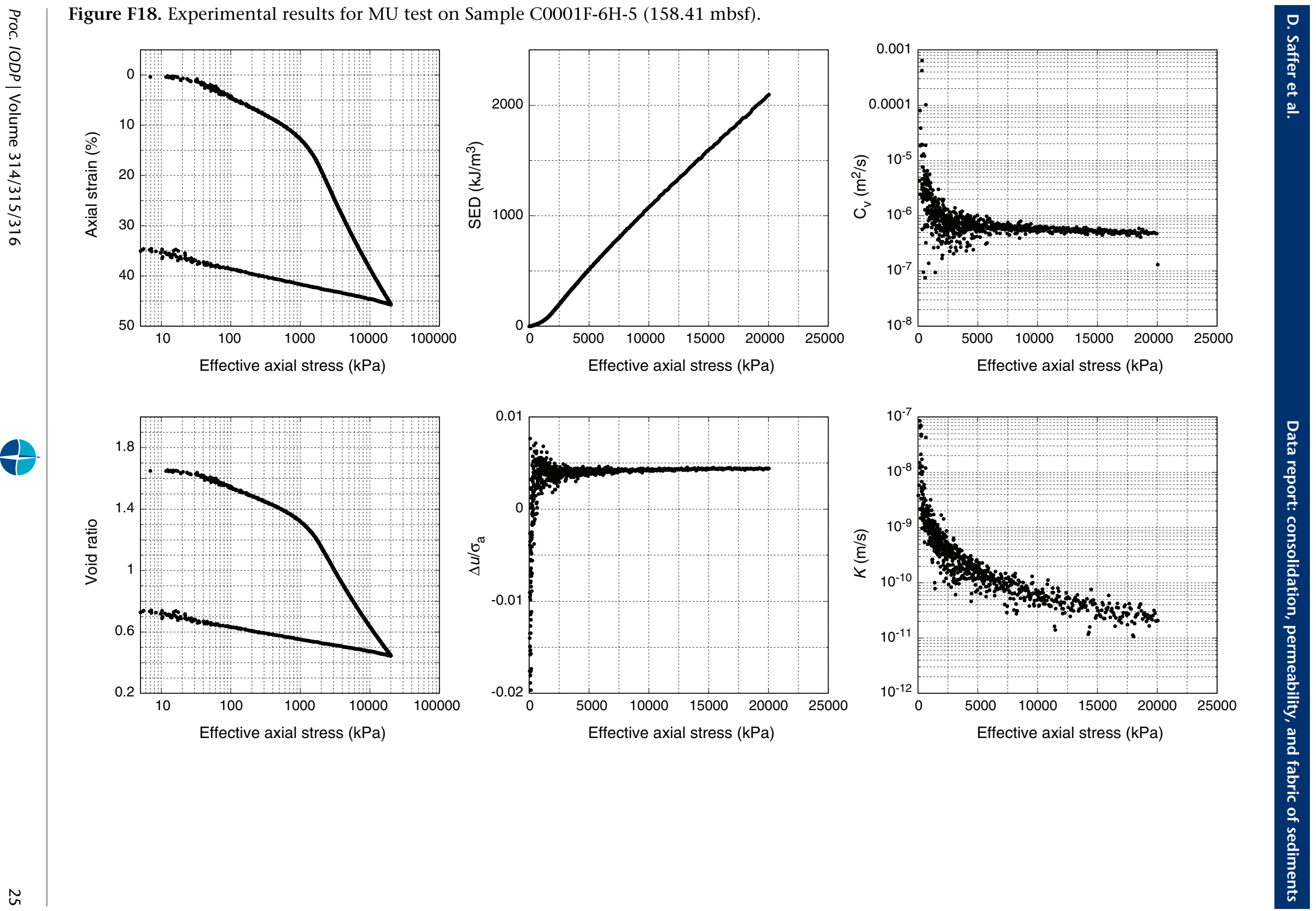
Figure F19. Time series data of effective axial stress $\left(\sigma_{a}{ }^{\prime}\right)$ and basal excess pore pressure $(\Delta u)$ for MU test on Sample C0001F-14H-2.

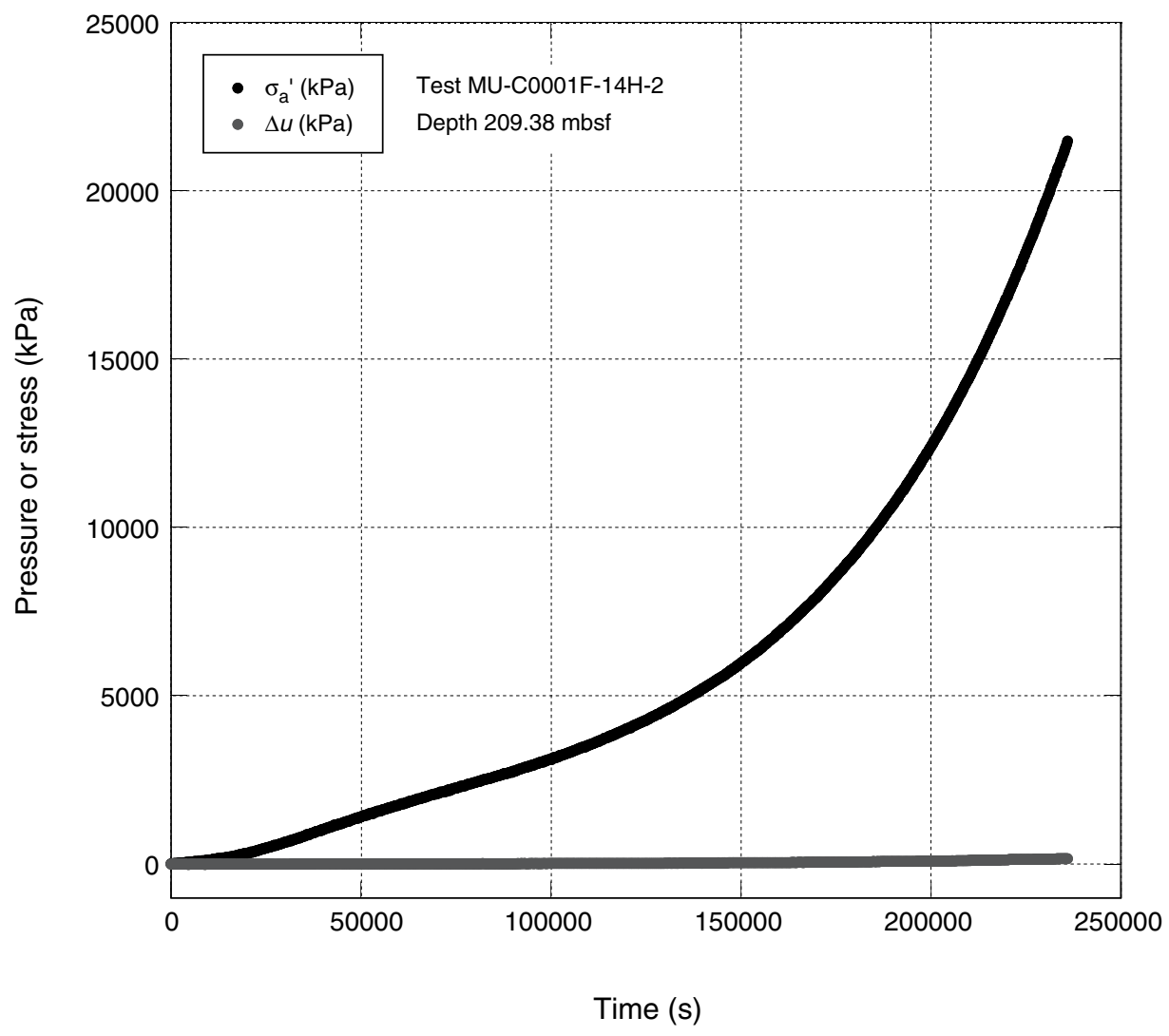



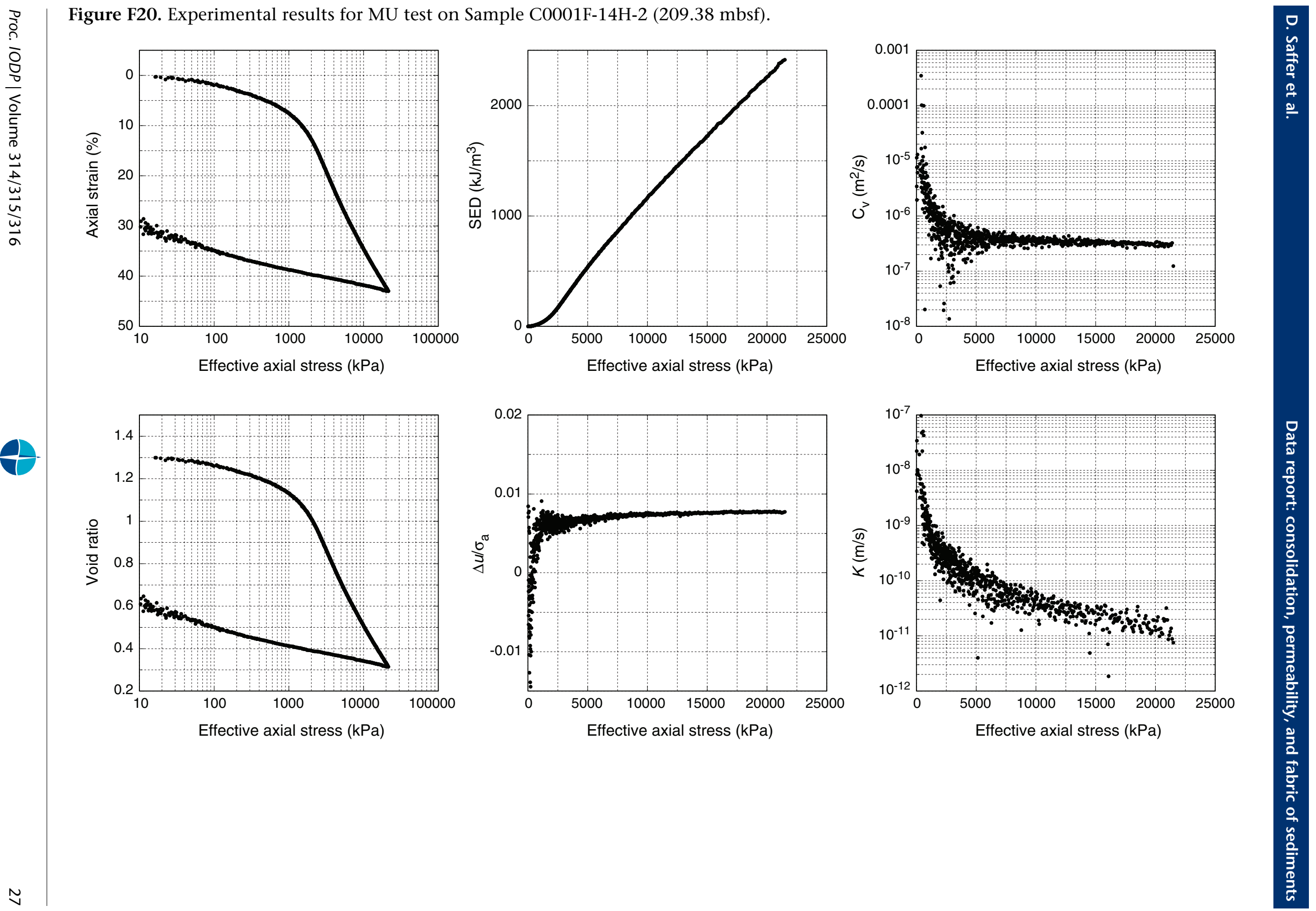
Figure F21. Time series data of effective axial stress $\left(\sigma_{a}{ }^{\prime}\right)$ and basal excess pore pressure $(\Delta u)$ for MU test on Sample C0001H-4R-6.

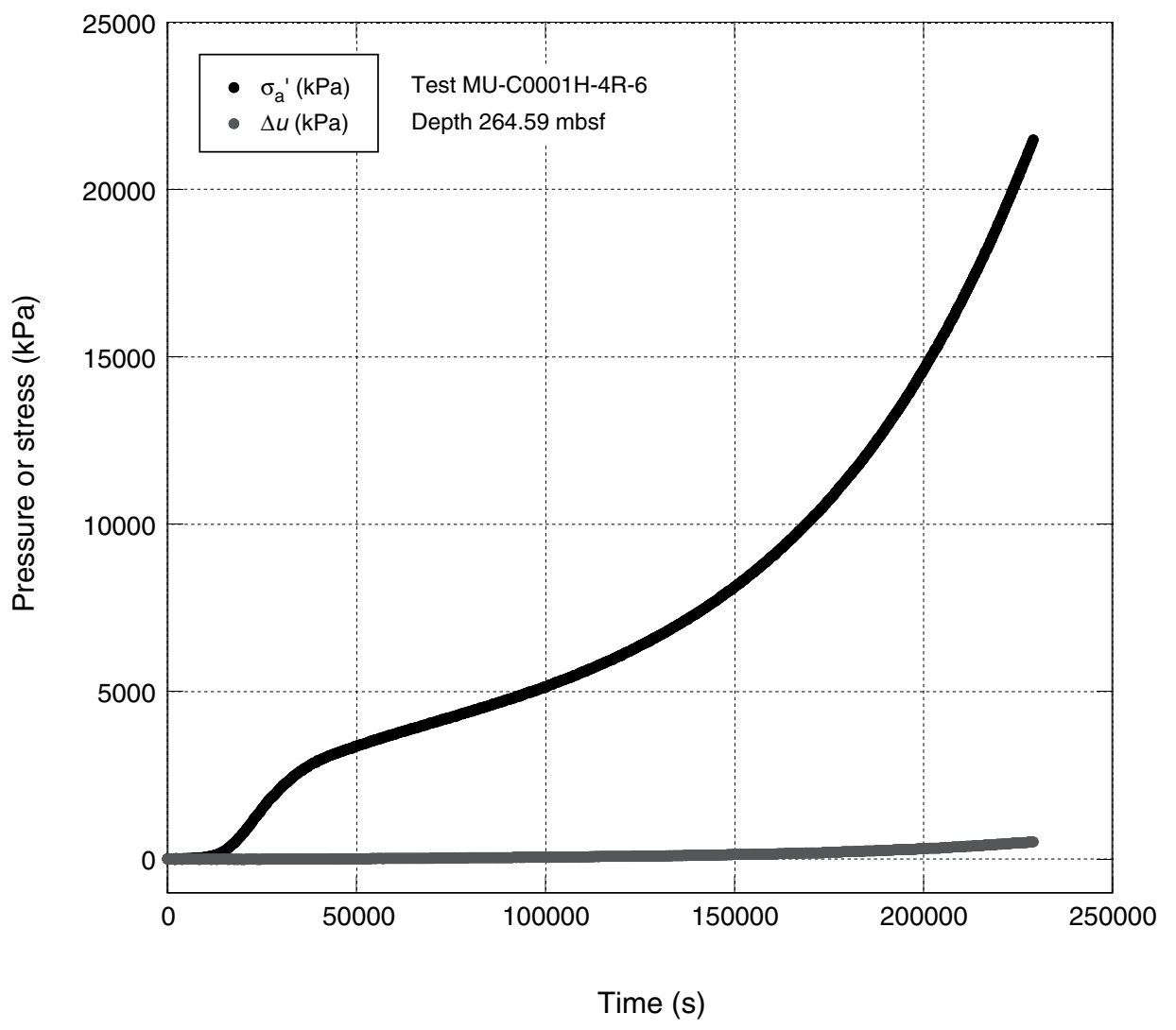


Figure F22. Experimental results for MU test on Sample C0001H-4R-6 (264.59 mbsf).
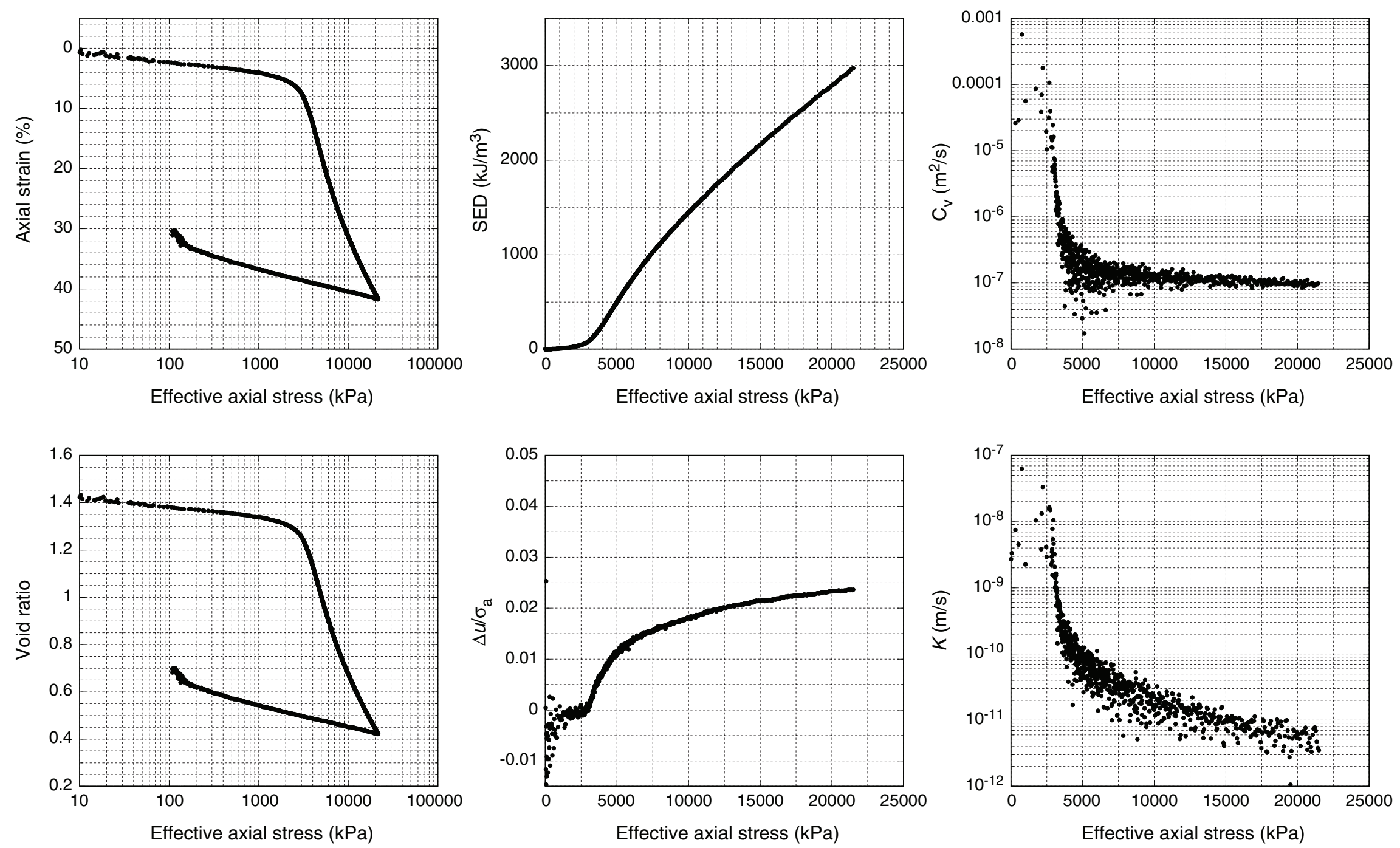
Figure F23. Time series data of effective axial stress $\left(\sigma_{a}{ }^{\prime}\right)$ and basal excess pore pressure $(\Delta u)$ for MU test on Sample C0001H-14R-6.

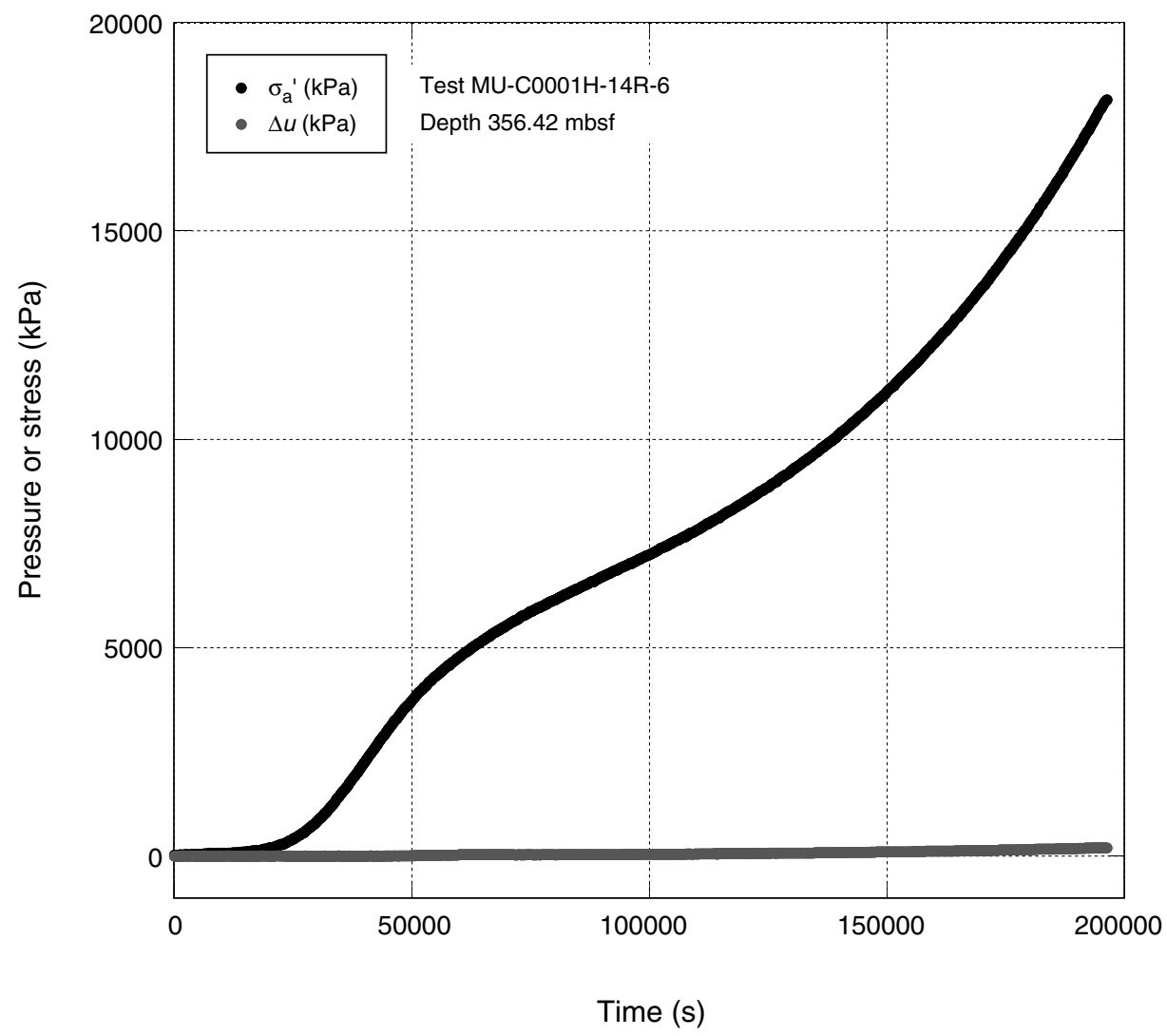



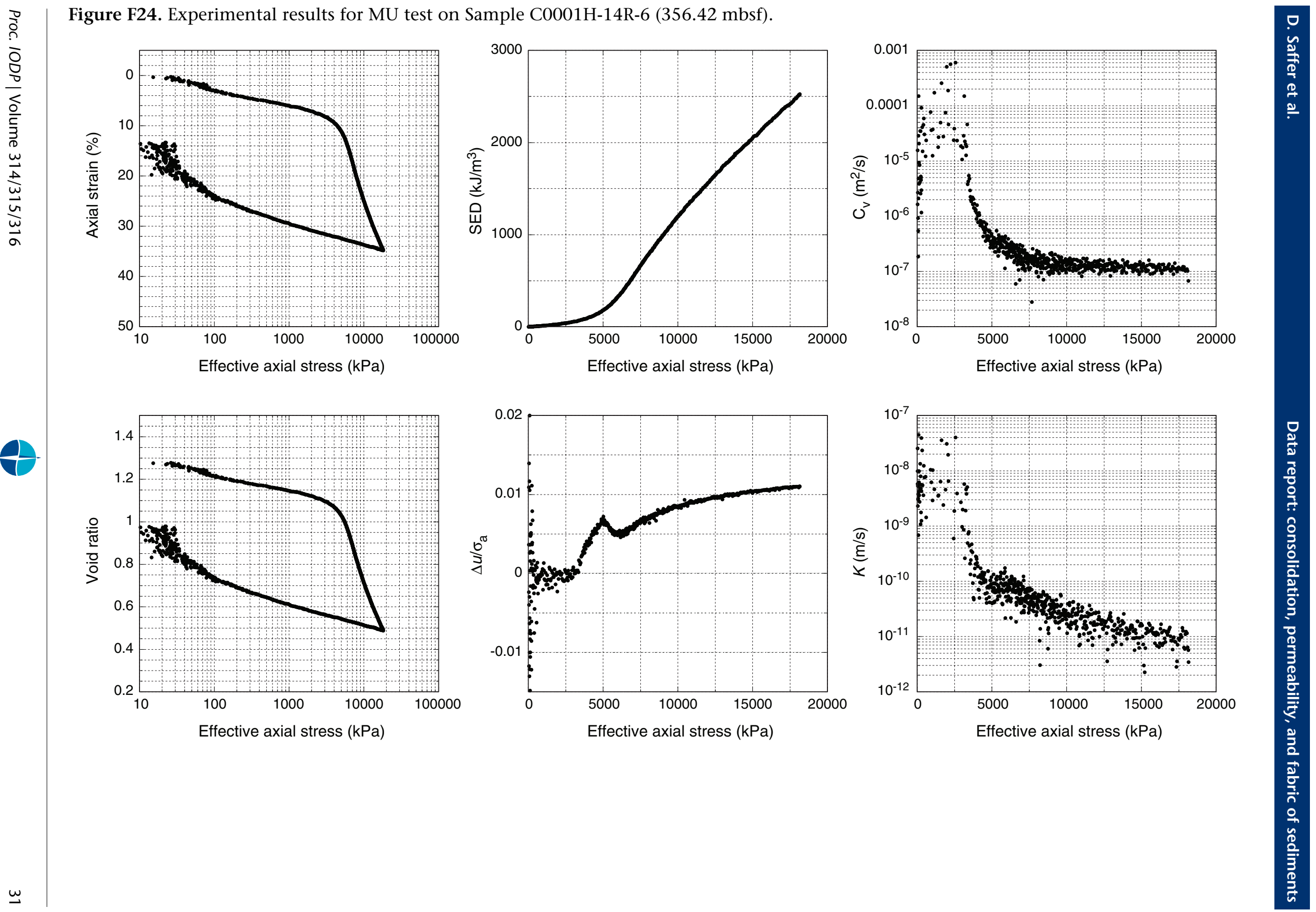
Figure F25. Time series data of effective axial stress $\left(\sigma_{a}{ }^{\prime}\right)$ and basal excess pore pressure $(\Delta u)$ for MU test on Sample C0001H-24R-3.

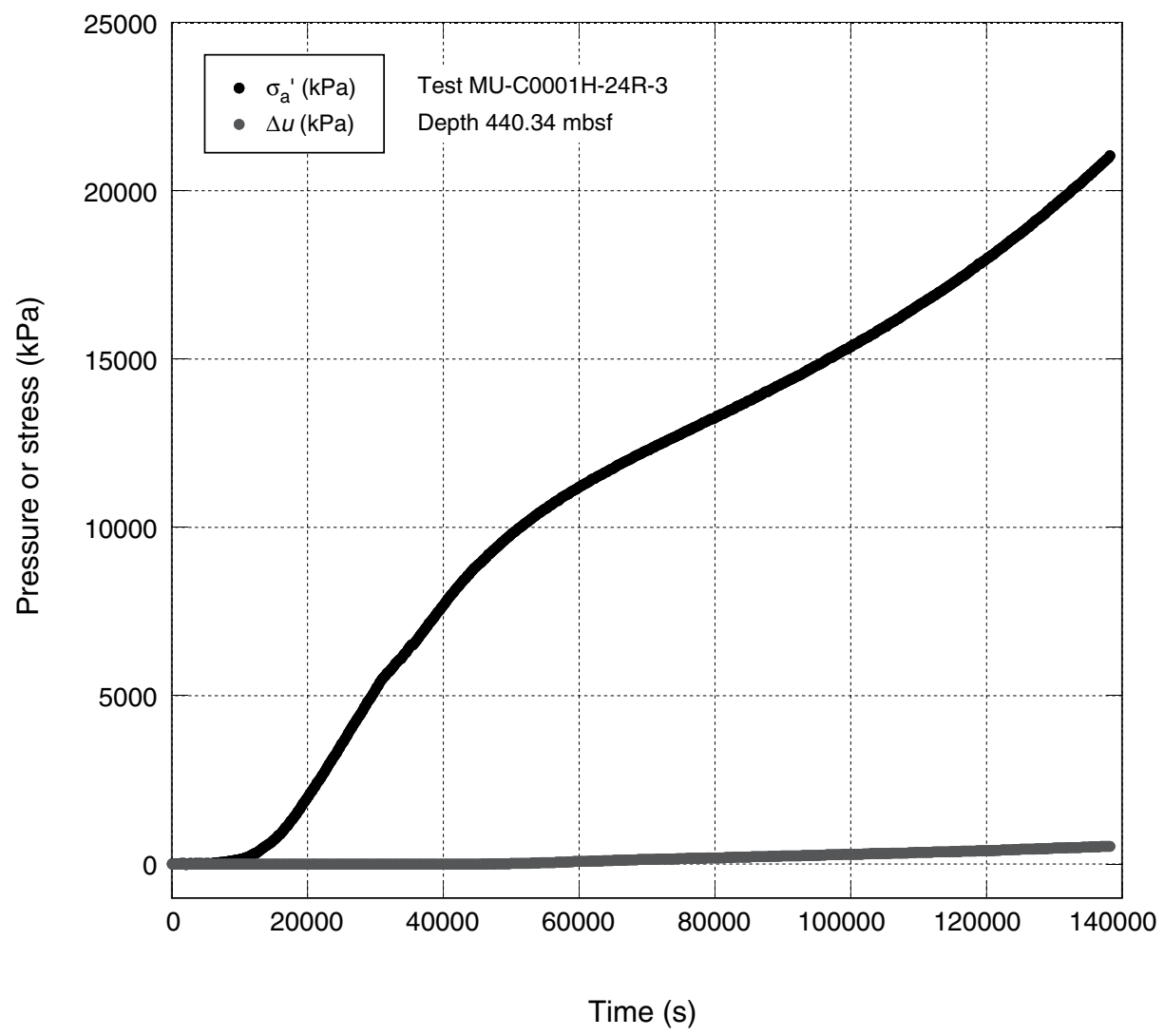



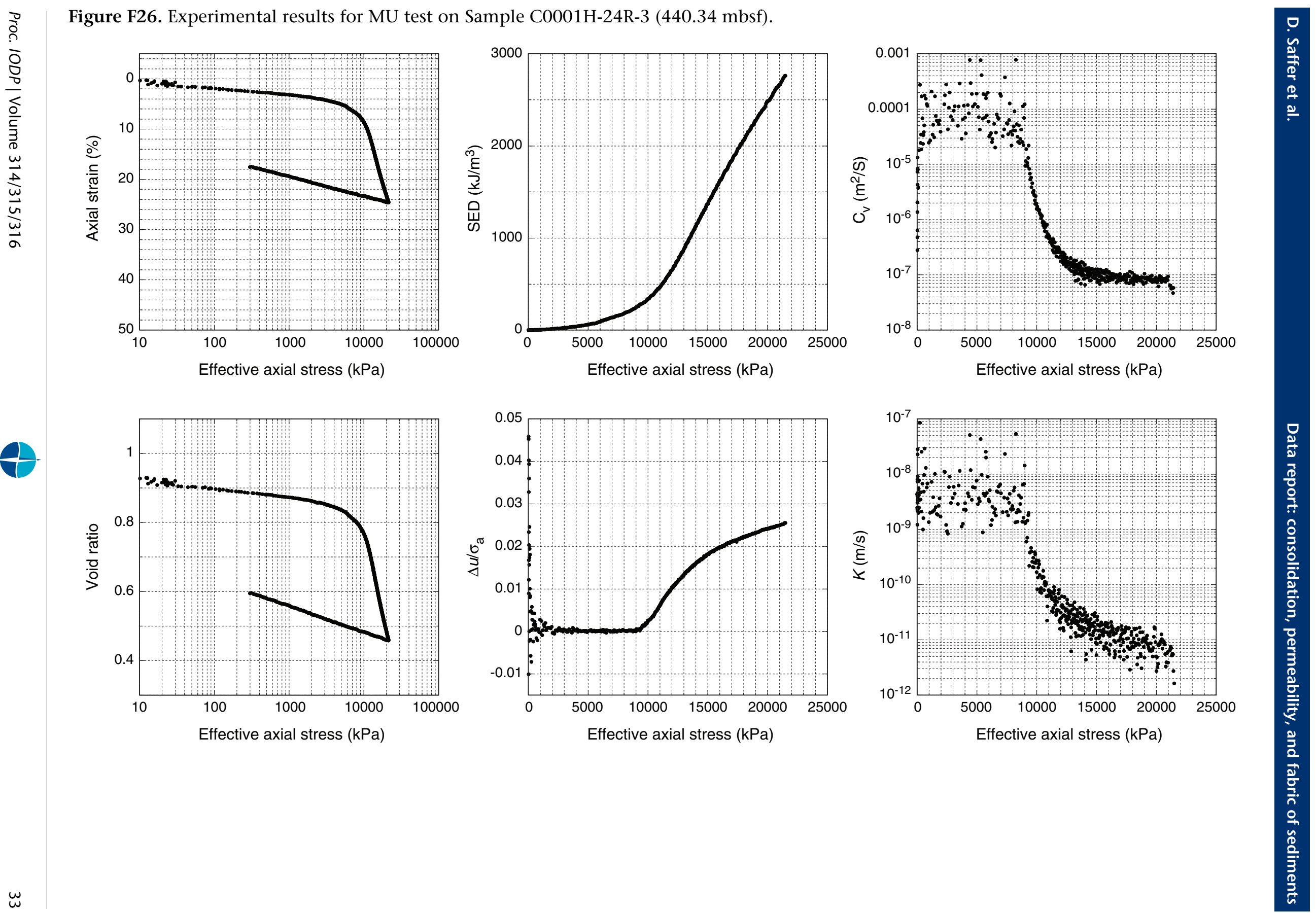
Figure F27. Time series data of effective axial stress $\left(\sigma_{\mathrm{a}}{ }^{\prime}\right)$ and basal excess pore pressure $(\Delta u)$ for PSU test U-136 on Sample C0004D-47R-2.

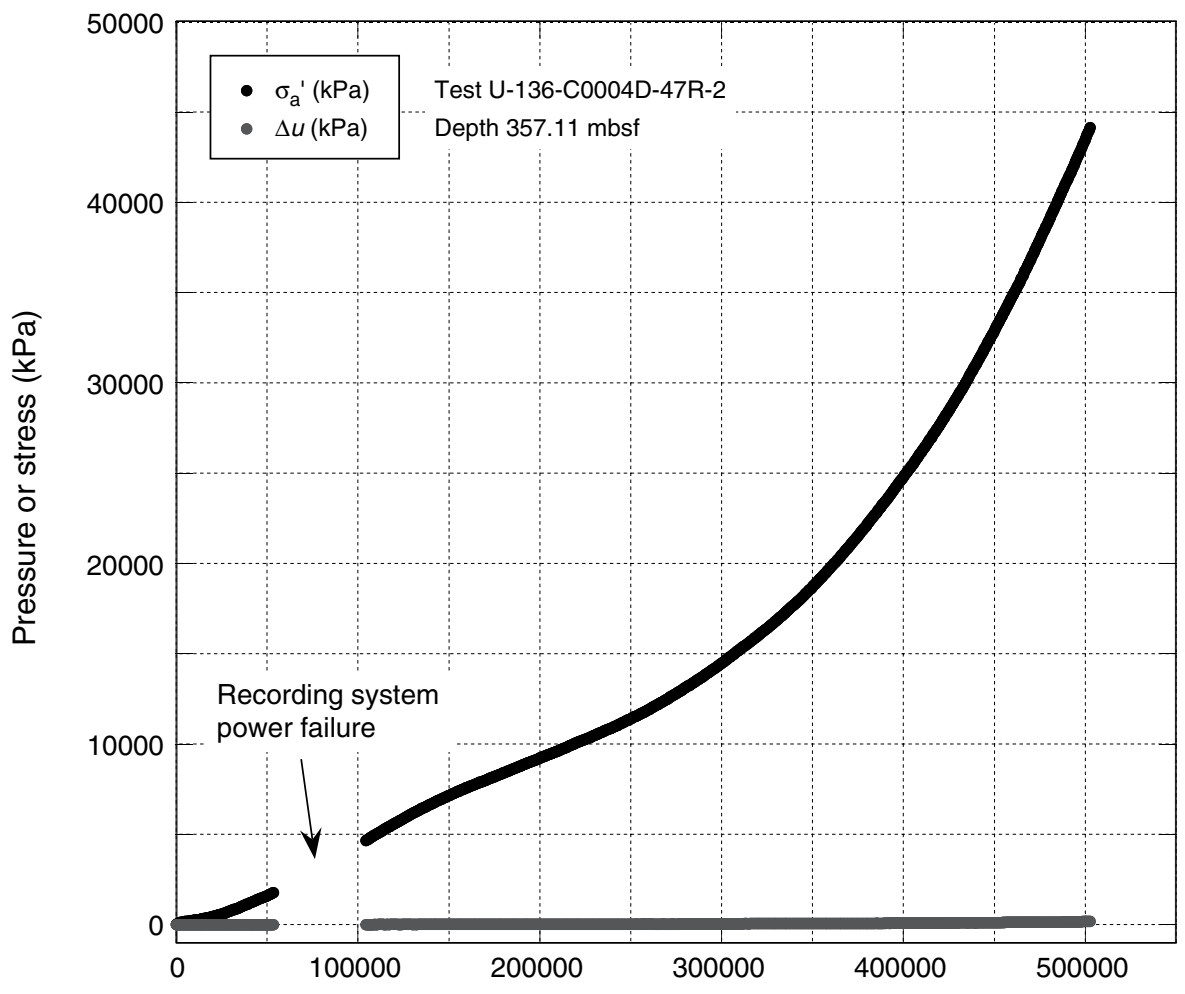

Time (s) 

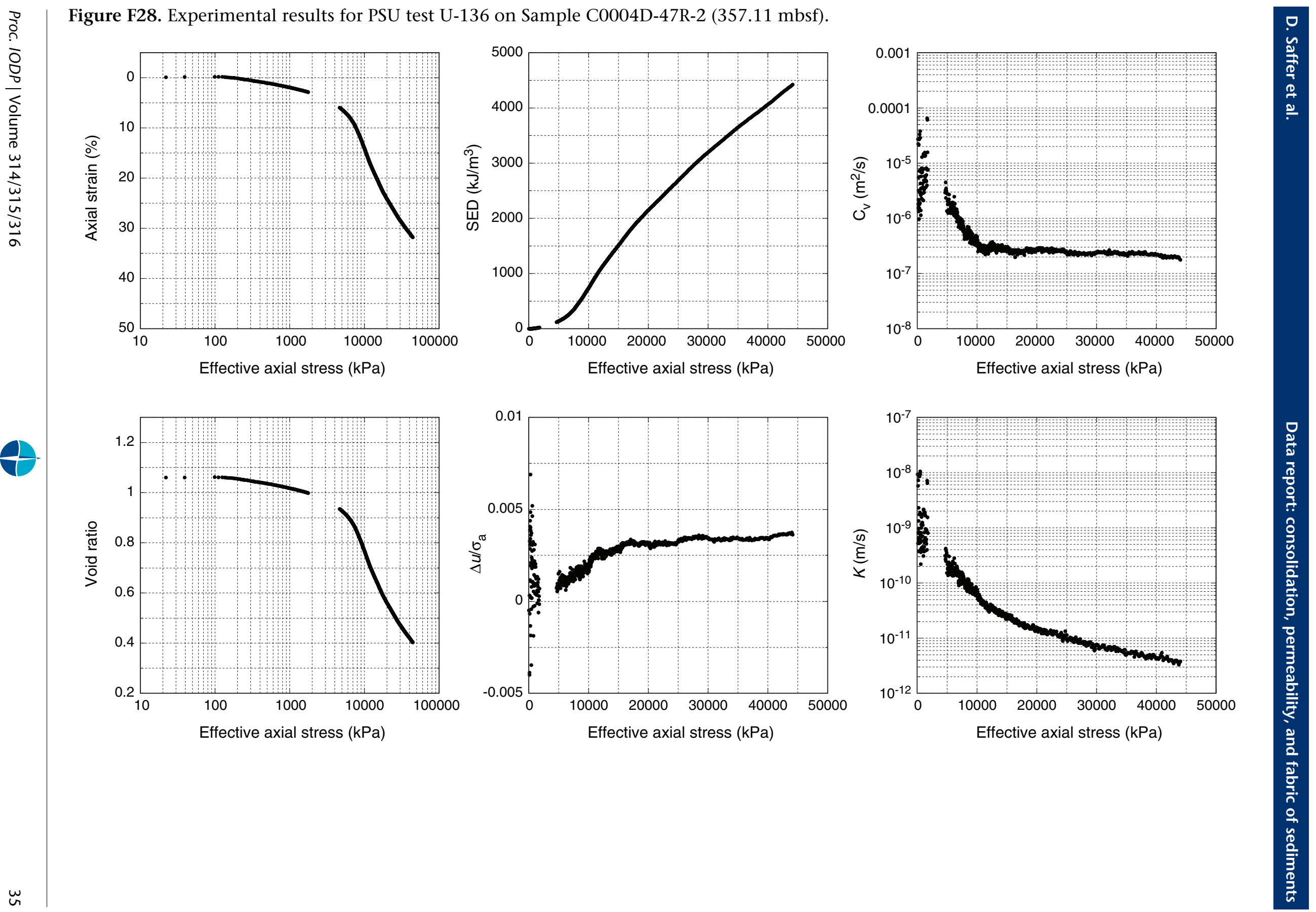
Figure F29. Time series data of effective axial stress $\left(\sigma_{a}{ }^{\prime}\right)$ and basal excess pore pressure $(\Delta u)$ for PSU test U-140 on Sample C0004D-51R-2.

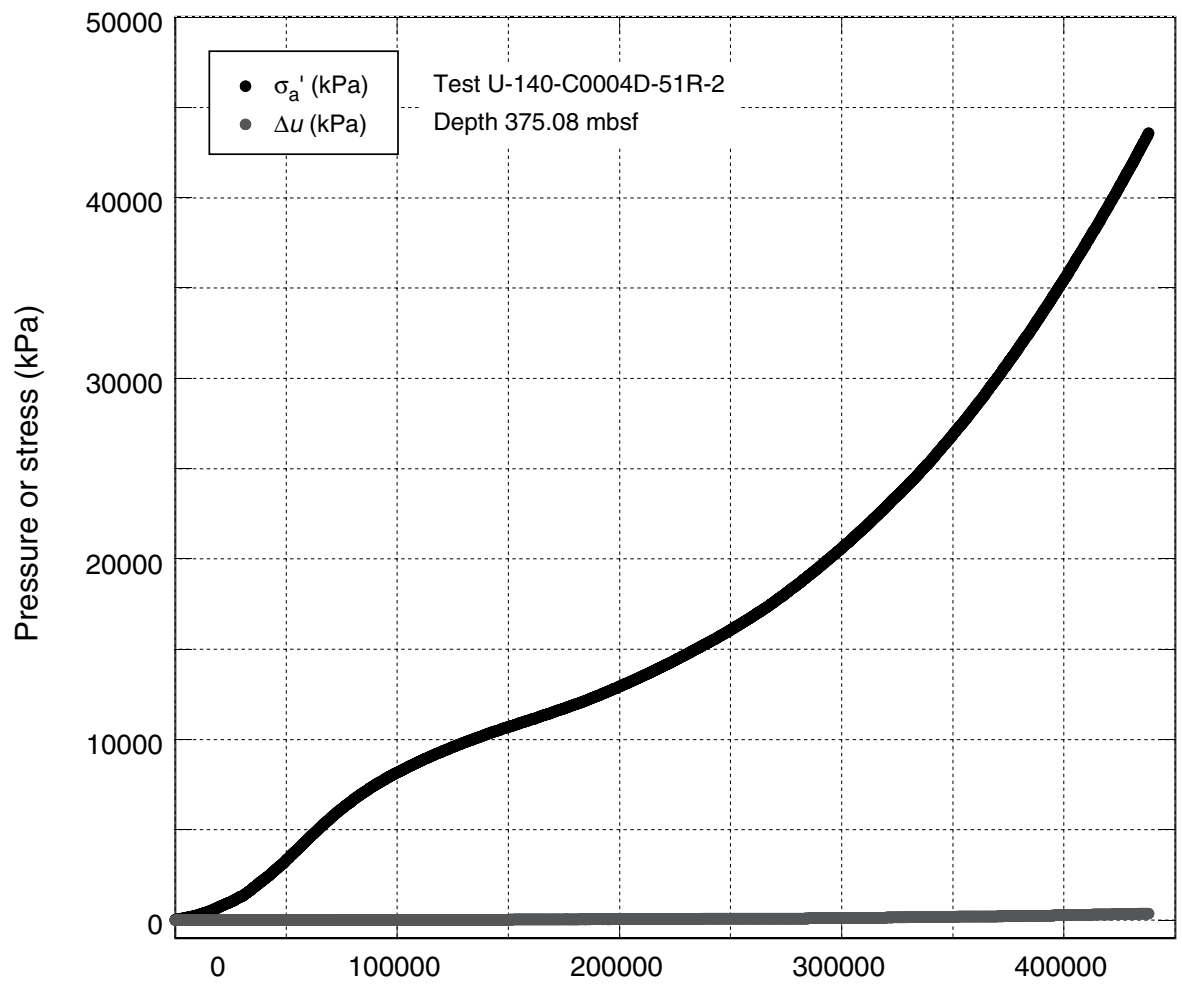

Time (s) 

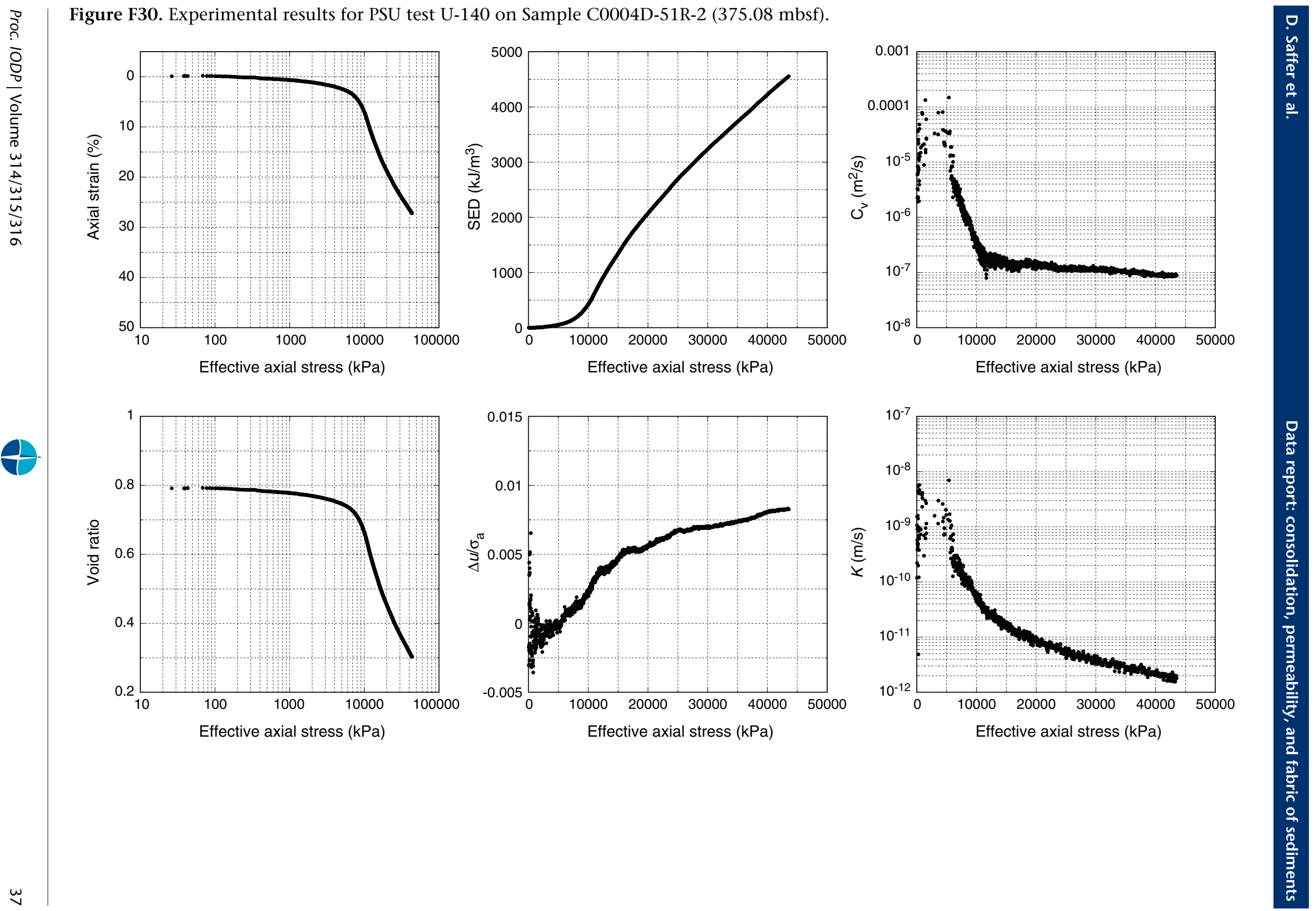
Figure F31. Time series data of effective axial stress $\left(\sigma_{a}{ }^{\prime}\right)$ and basal excess pore pressure $(\Delta u)$ for MU test on Sample C0004D-52R-3.

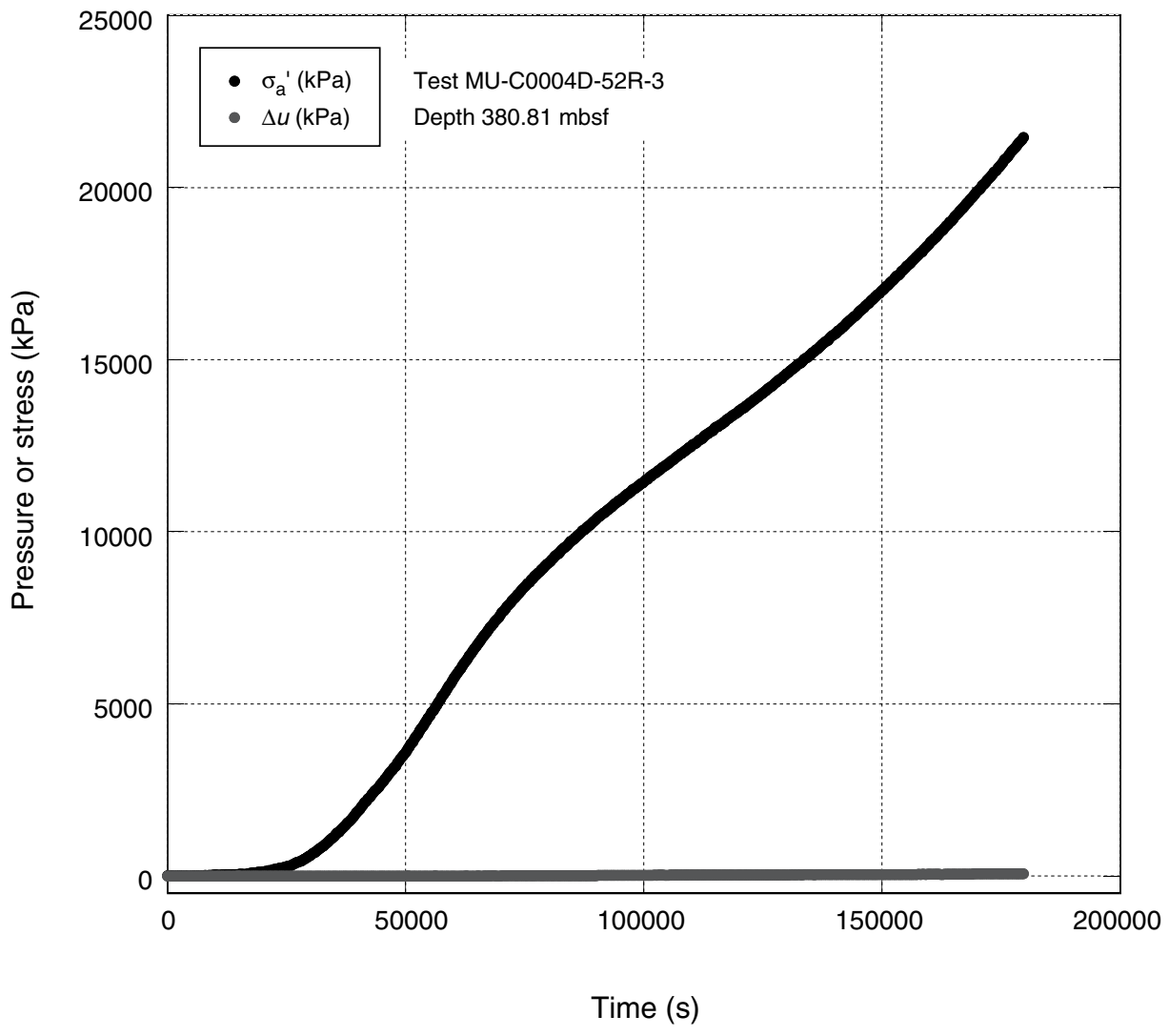


Figure F32. Experimental results for MU test on Sample C0004D-52R-3 (380.81 mbsf).
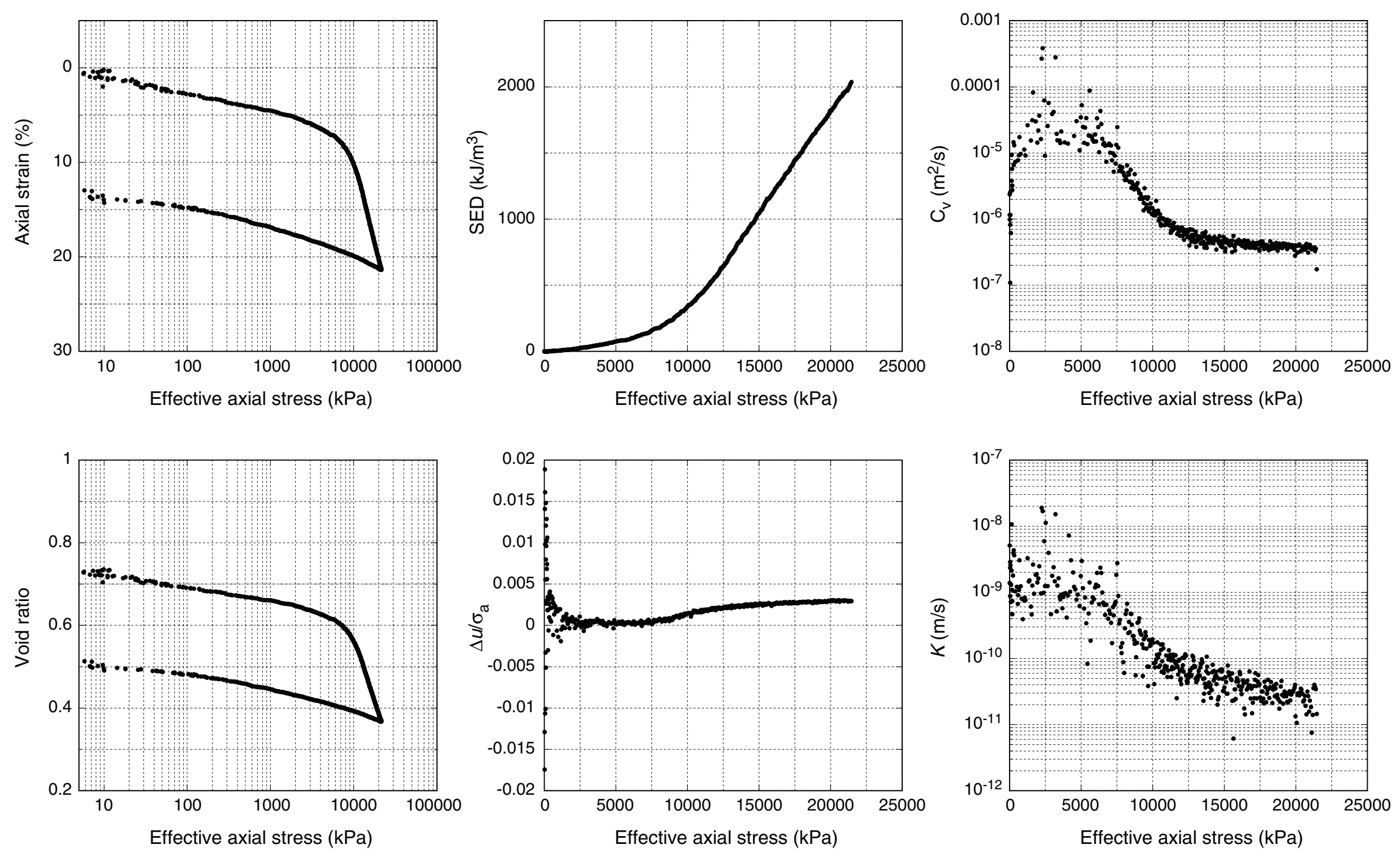
Figure F33. Time series data of effective axial stress $\left(\sigma_{a}{ }^{\prime}\right)$ and basal excess pore pressure $(\Delta u)$ for PSU test U-127 on Sample C0008C-9H-5.

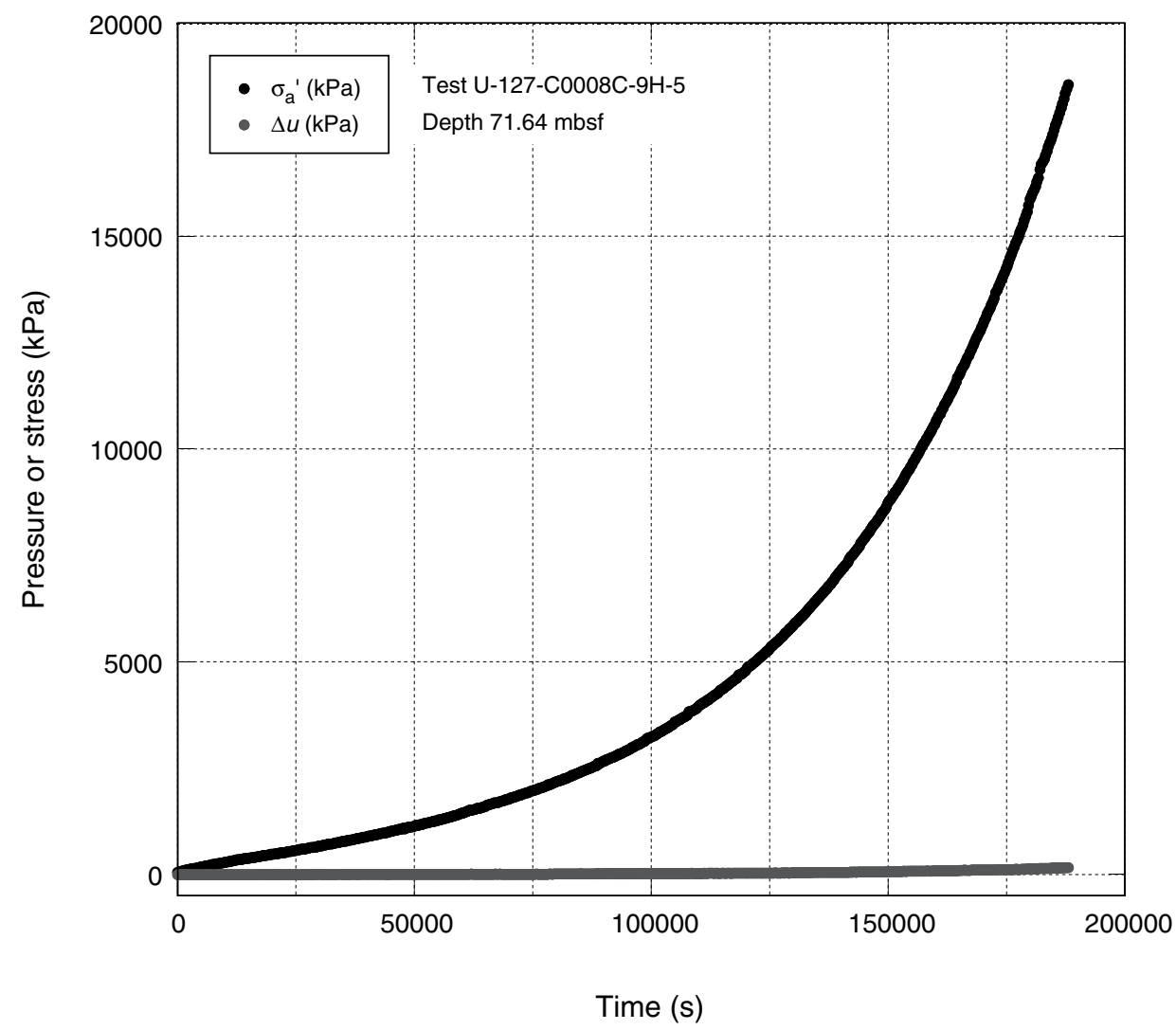



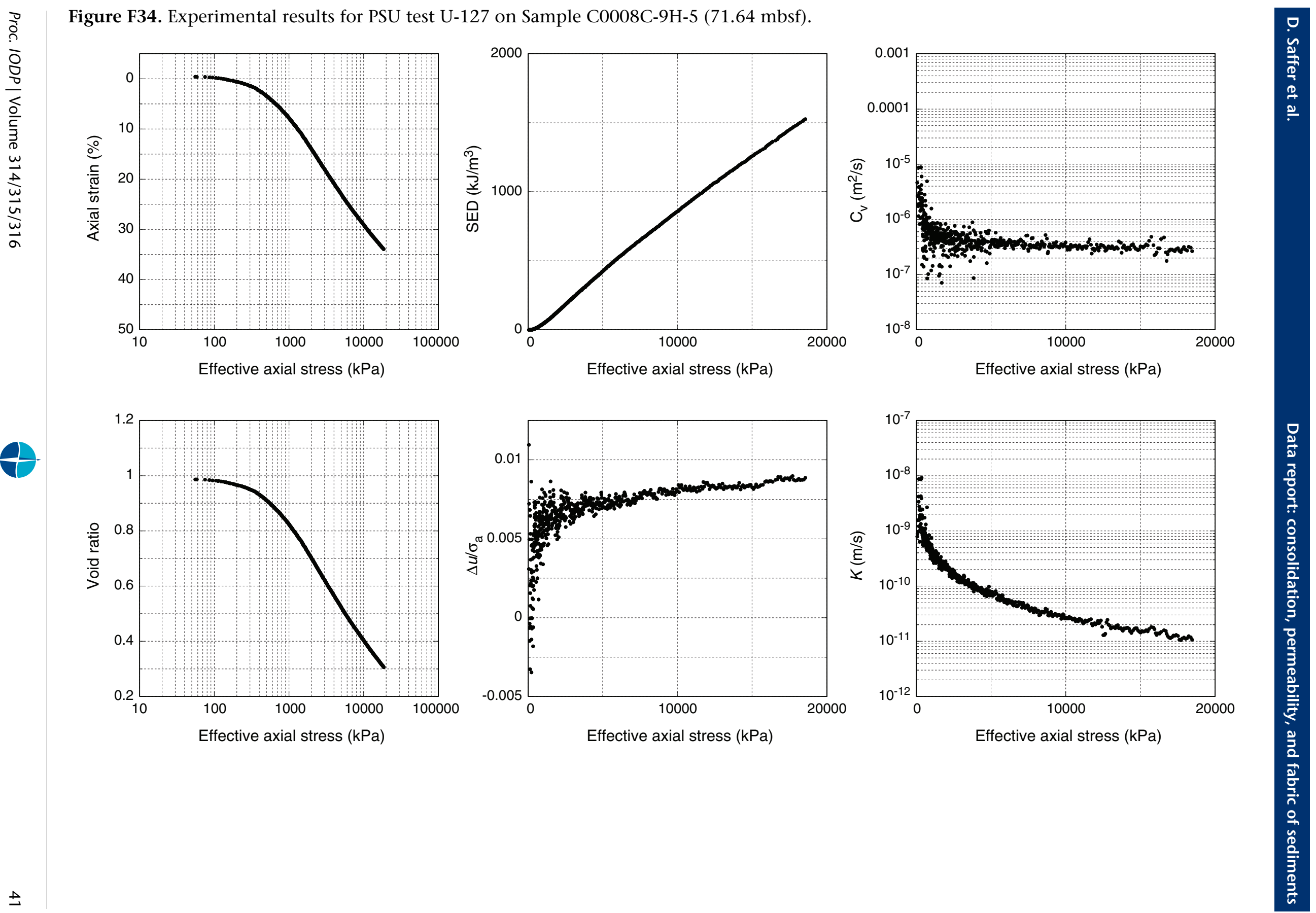
Figure F35. Time series data of effective axial stress $\left(\sigma_{a}{ }^{\prime}\right)$ and basal excess pore pressure $(\Delta u)$ for MU test on Sample C0008A-17H-8.

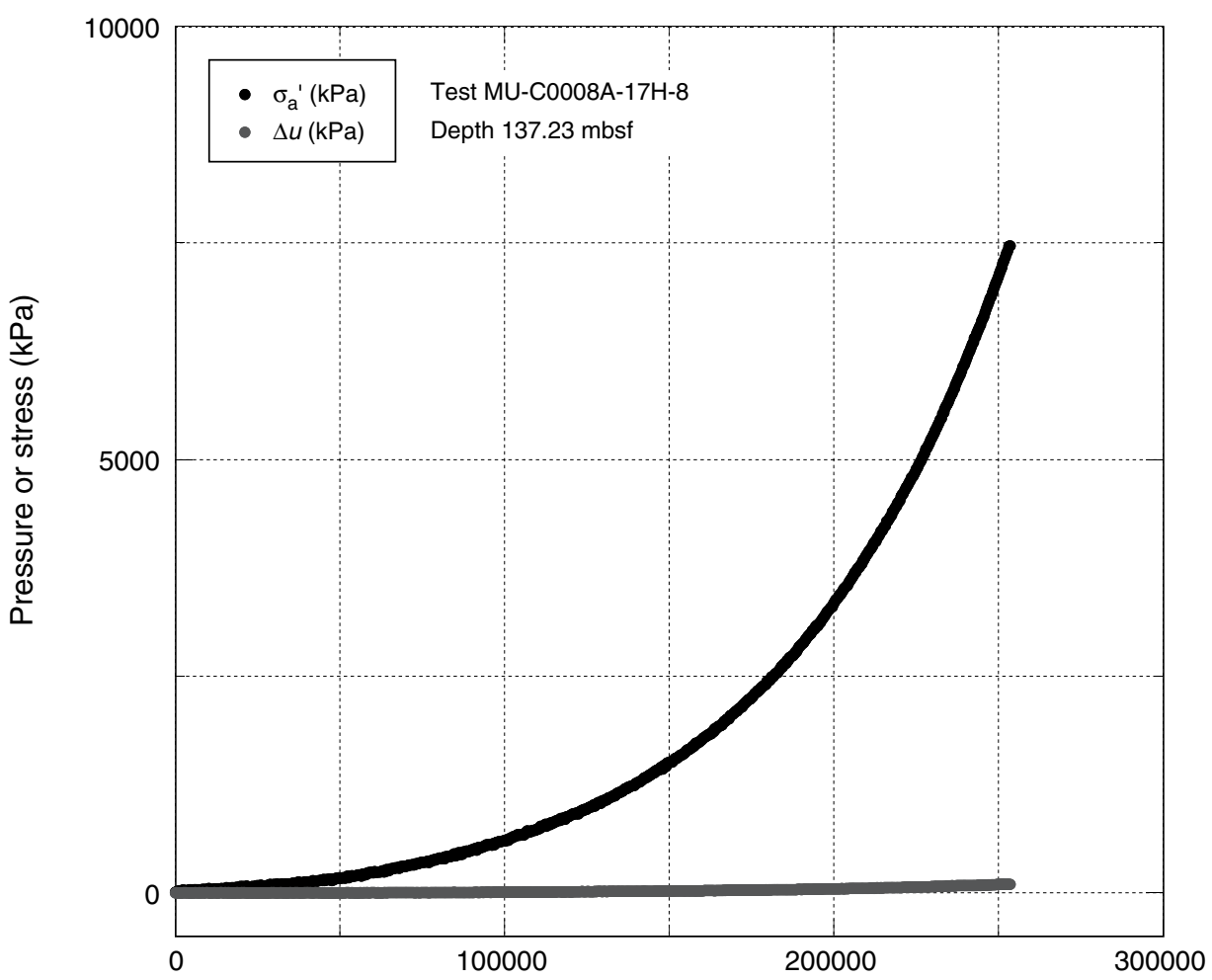

Time (s) 

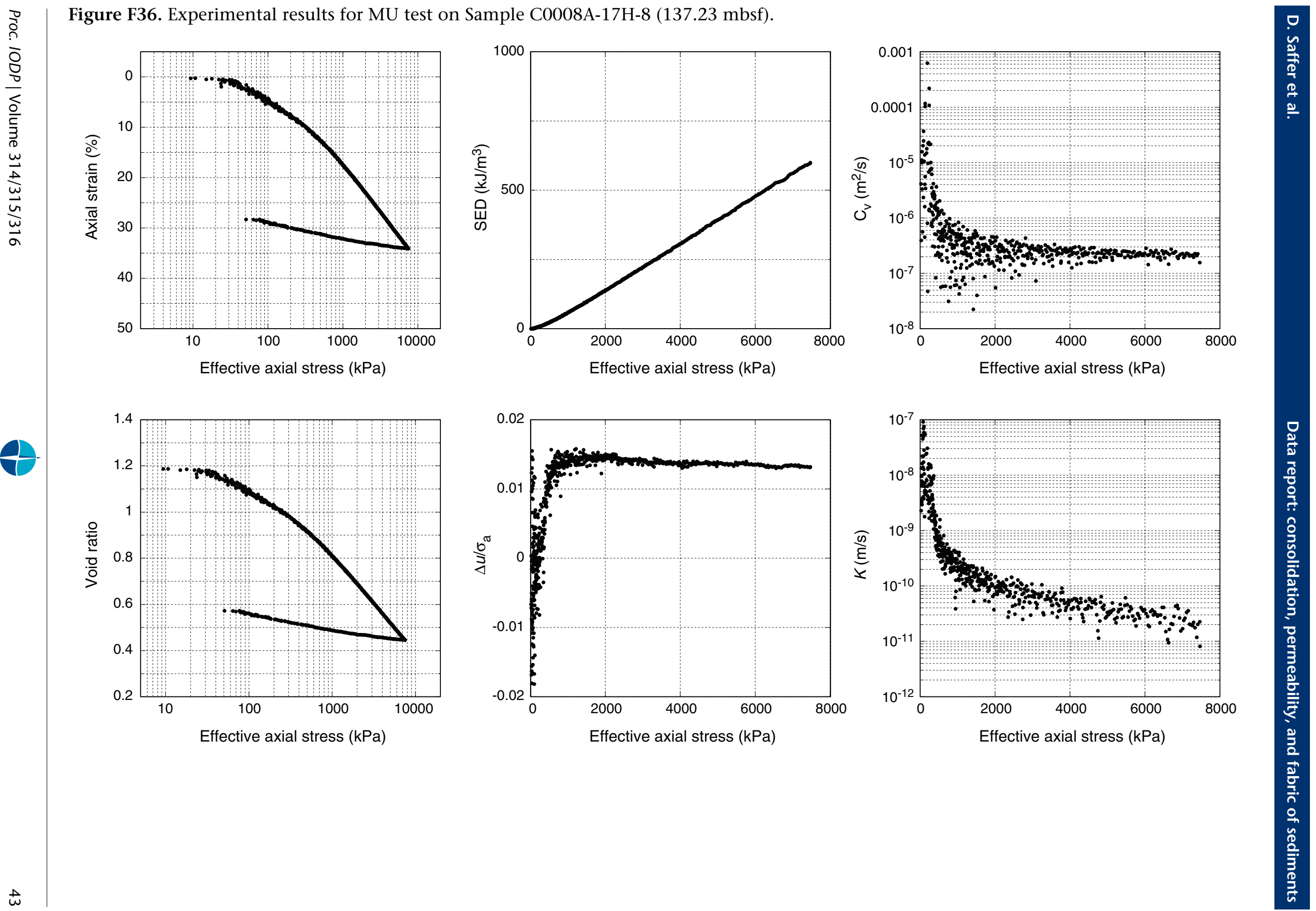
Figure F37. Time series data of effective axial stress $\left(\sigma_{a}{ }^{\prime}\right)$ and basal excess pore pressure $(\Delta u)$ for MU test on Sample C0008C-23X-6A.

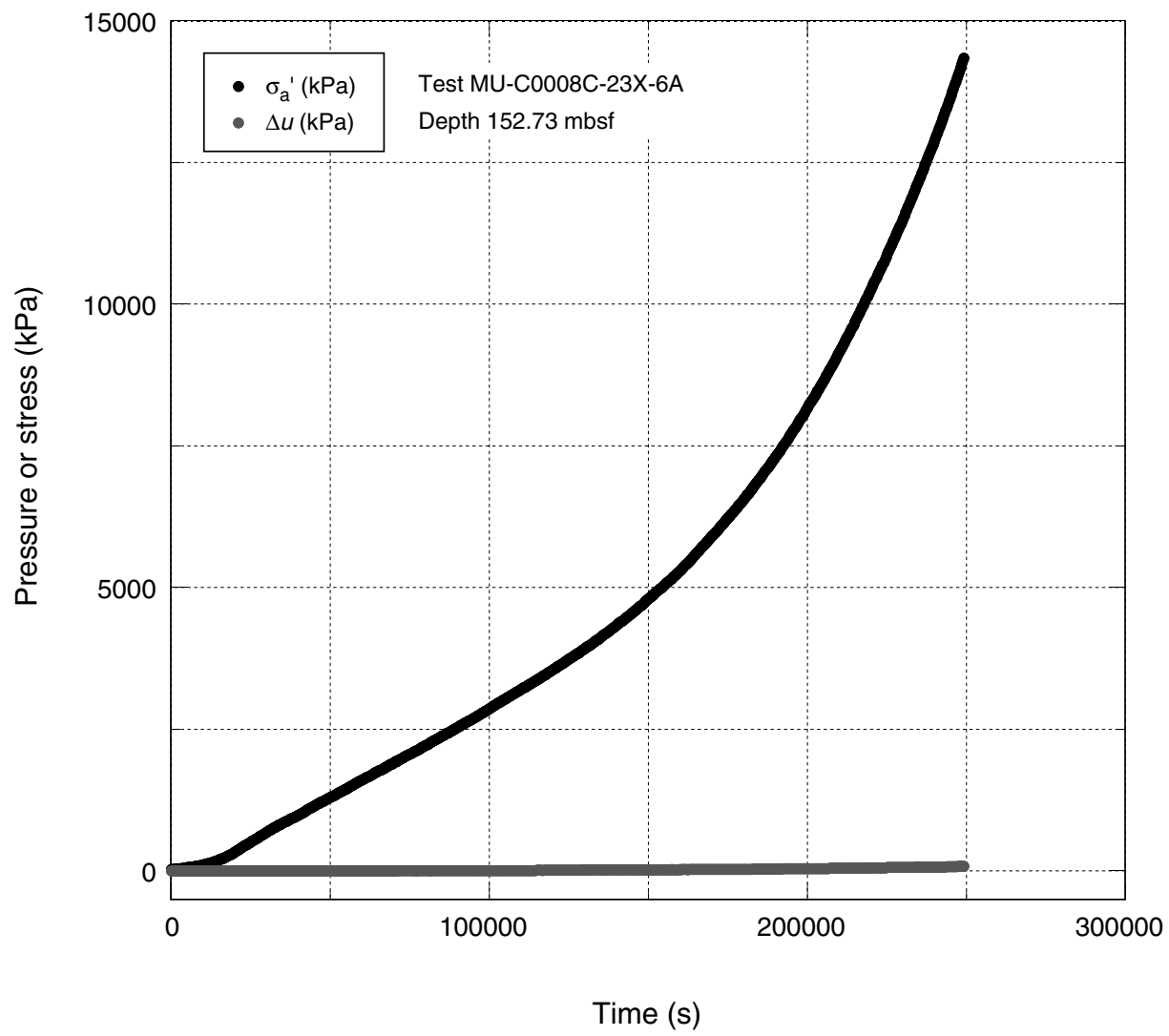



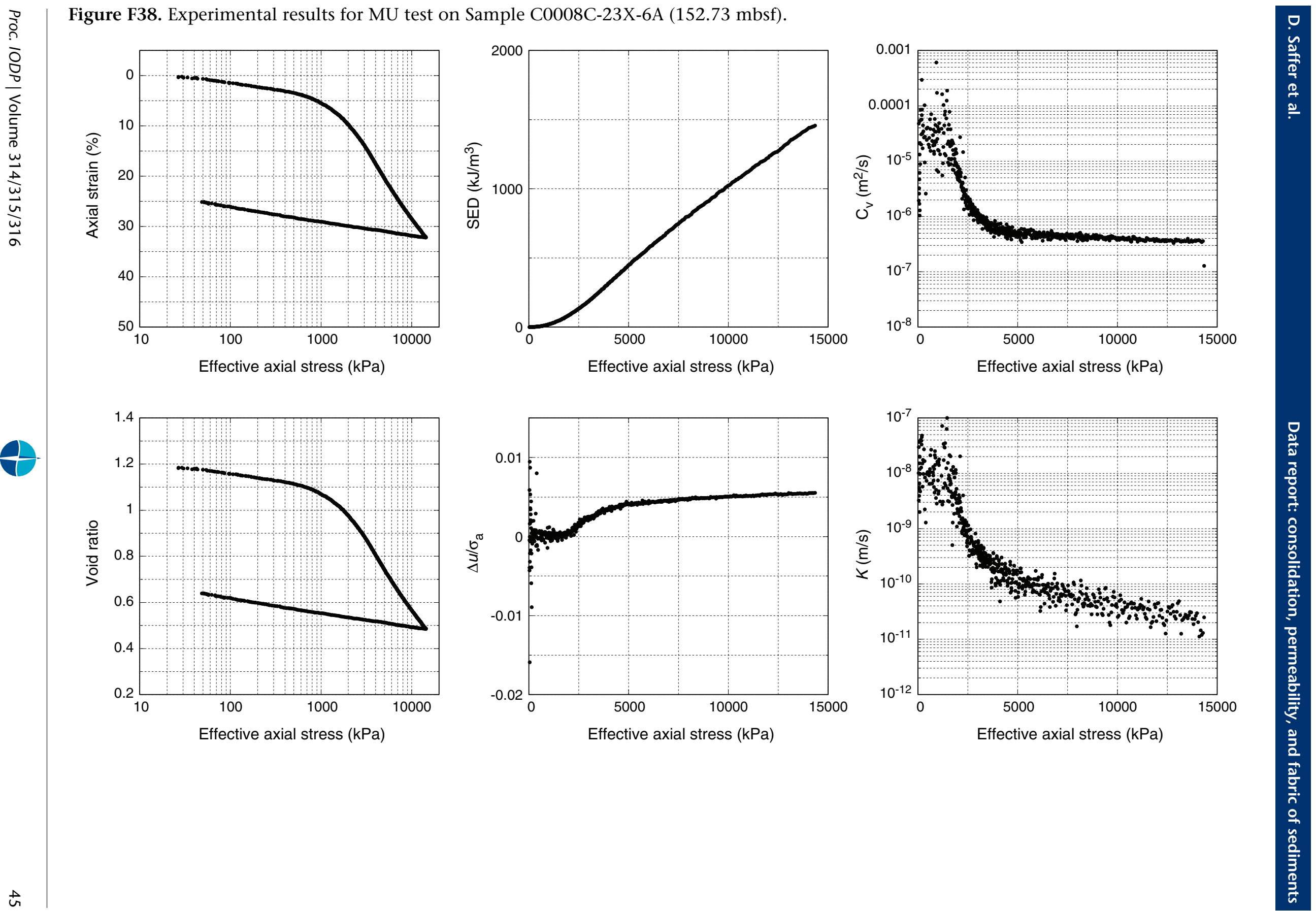
Figure F39. Time series data of effective axial stress $\left(\sigma_{a}{ }^{\prime}\right)$ and basal excess pore pressure $(\Delta u)$ for MU test on Sample C0008C-23X-6B.

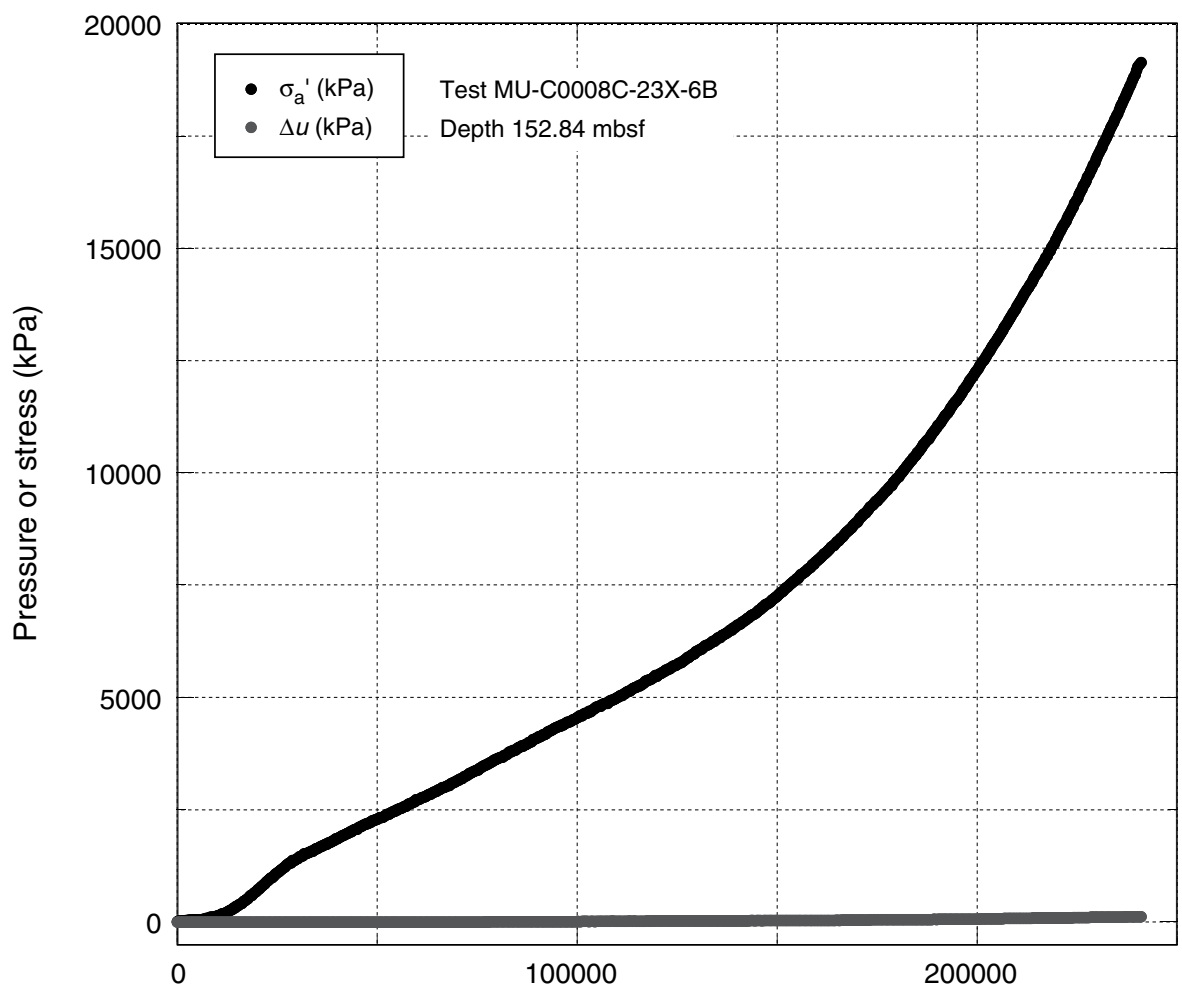

Time (s) 

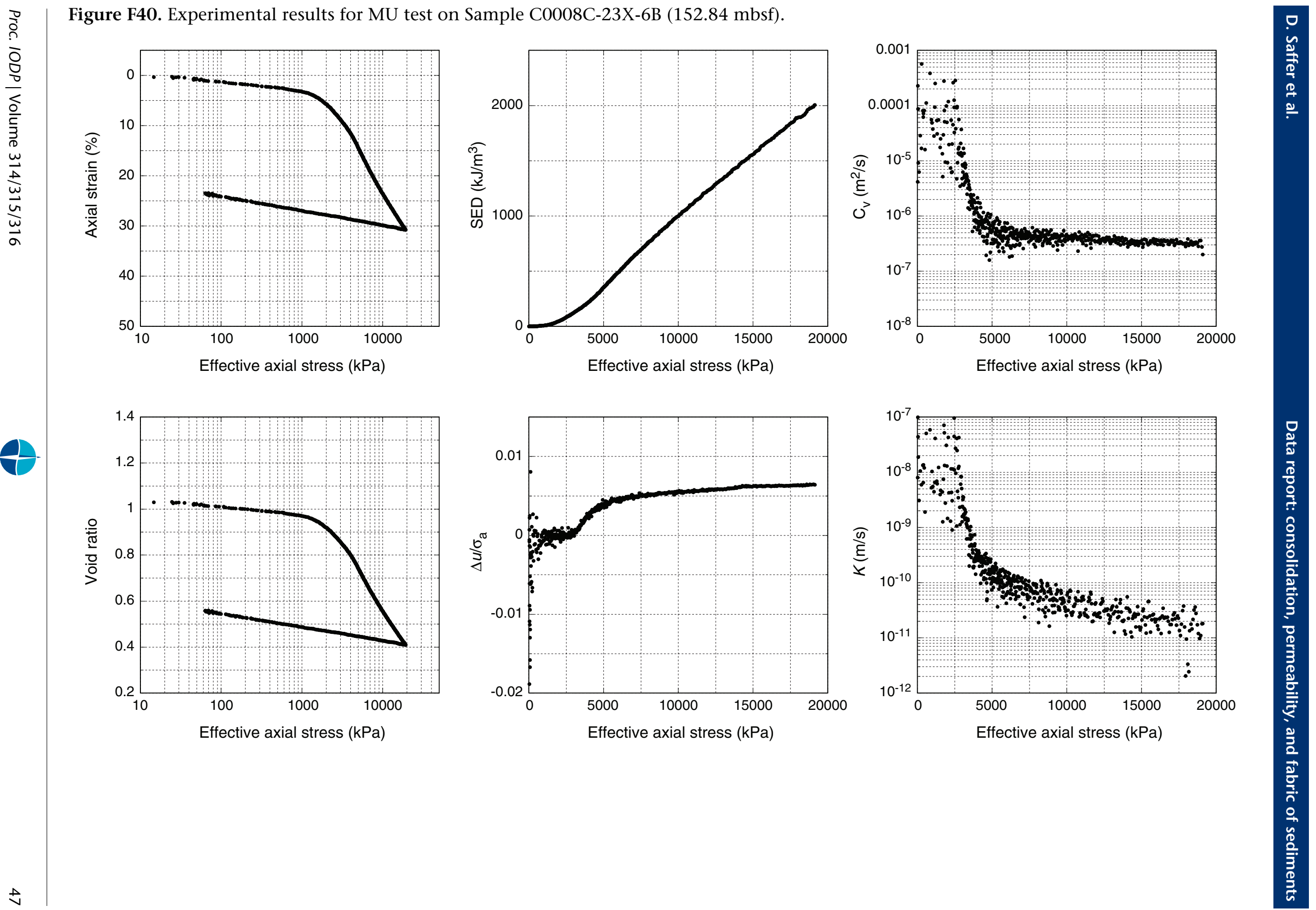
Figure F41. Time series data of effective axial stress $\left(\sigma_{a}{ }^{\prime}\right)$ and basal excess pore pressure $(\Delta u)$ for MU test on Sample C0008A-27H-2.

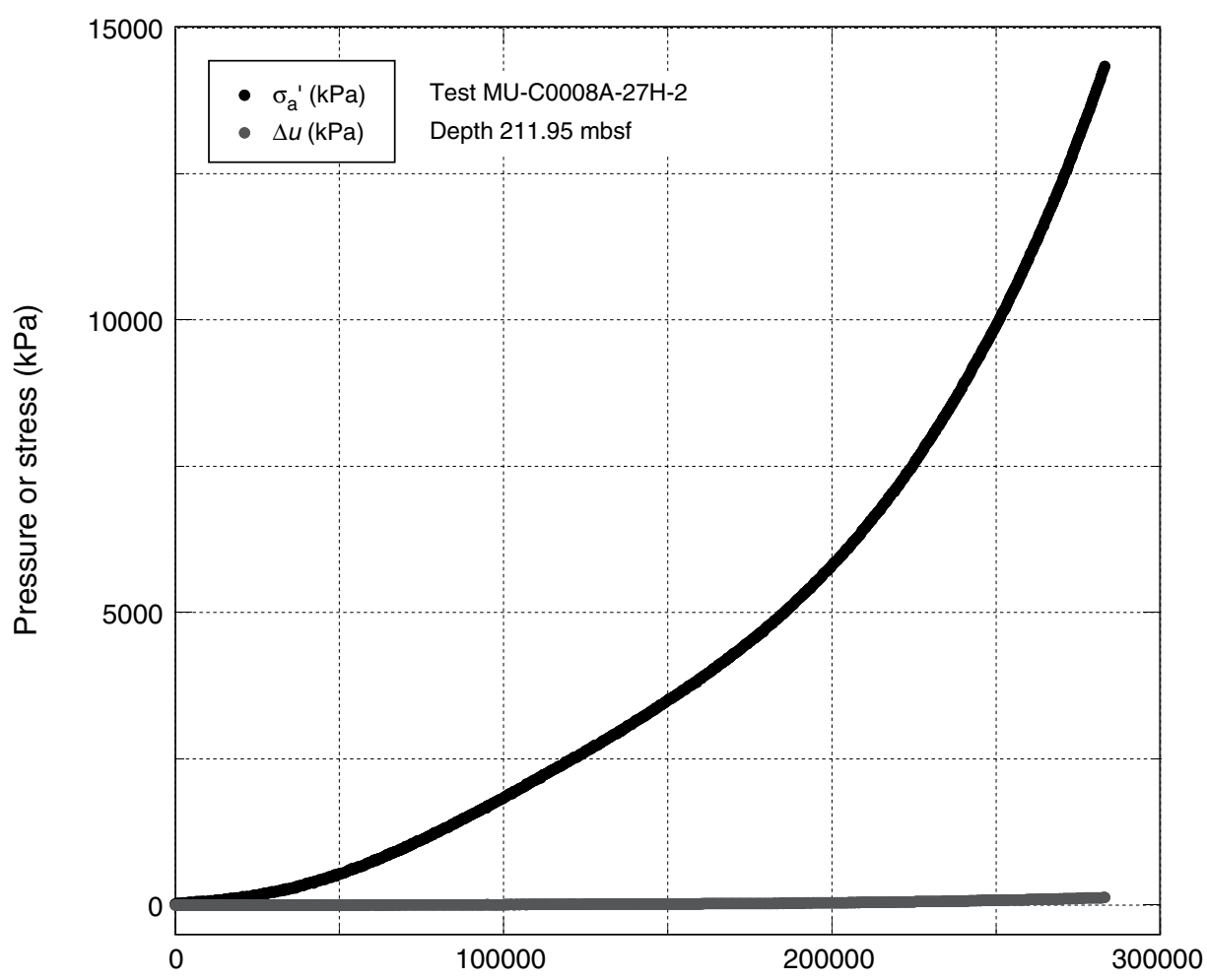

Time (s) 

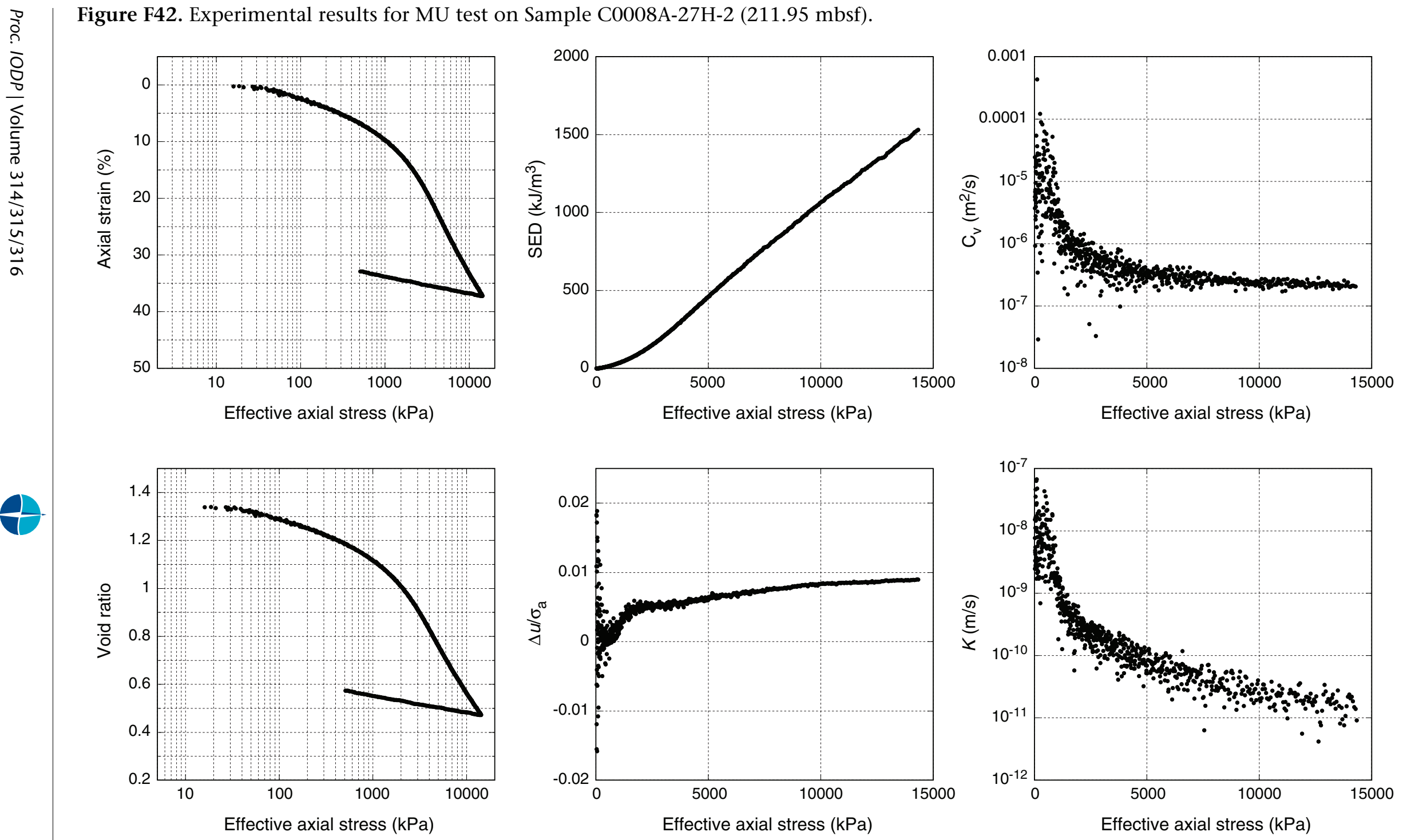
Figure F43. Compilation of CRS permeabilities for samples from the accreted wedge at Sites C0001, C0004, and C0008 obtained with Equation 5, plotted as a function of (A) effective axial stress and (B) porosity. In CRS tests, data are generally only considered to be reliable once the strain distribution within the sample is steady-state (ASTM International, 2006); thus, data for the transient phases of the test are not used in the compilation.
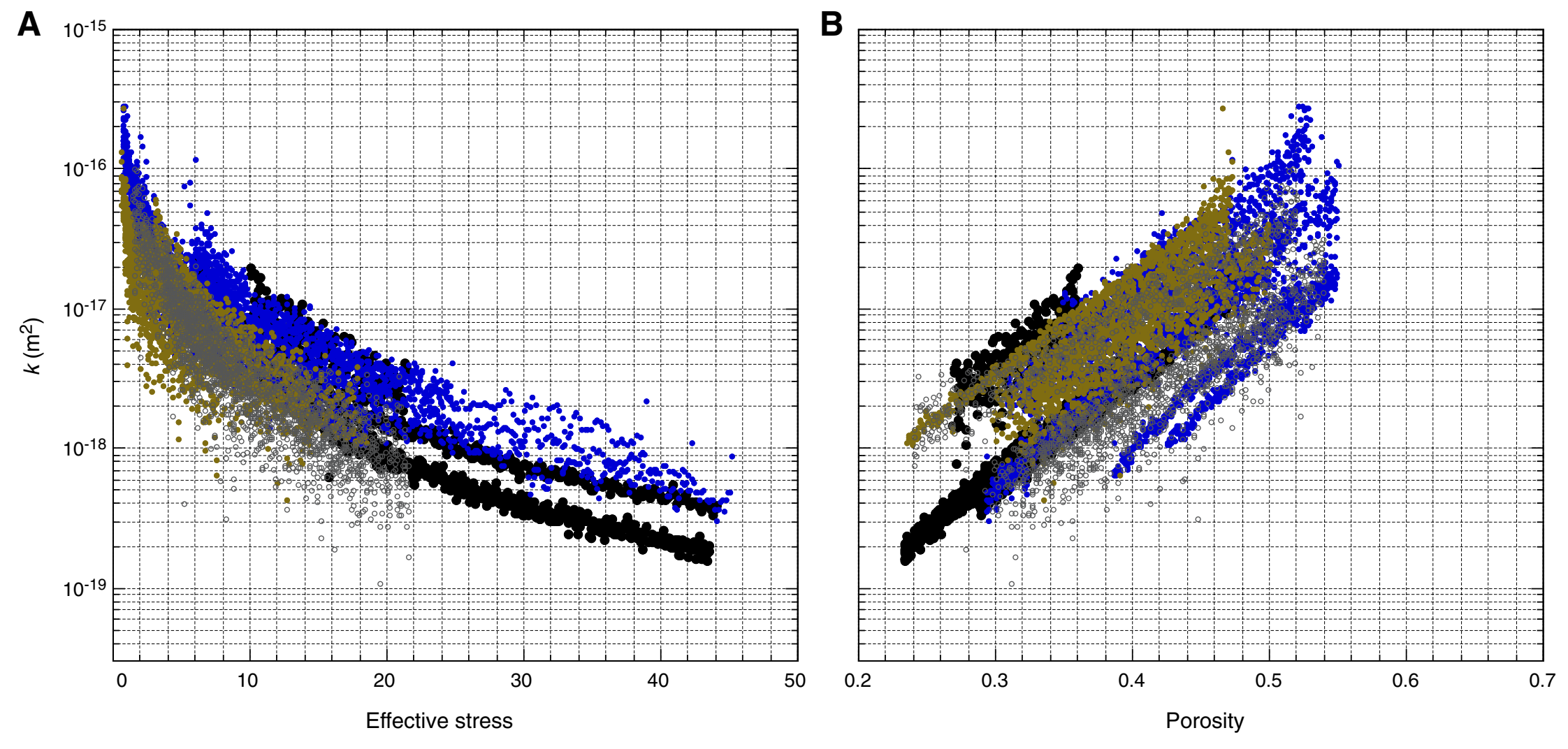

- Site C0004 - Site C0008 - Site C0001 (slope sediment) 。 Site C0001 (wedge) 
Figure F44. Estimated in situ hydraulic conductivity as a function of depth for Sites C0001, C0004, and C0008, determined by projecting the permeability-porosity trend for each sample to the value at the in situ void ratio and accounting for in situ fluid viscosity as a function of estimated temperature downsection, as reported in Table T3. MU = specimen data obtained at the University of Missouri; PSU = specimen data obtained at The Pennsylvania State University.

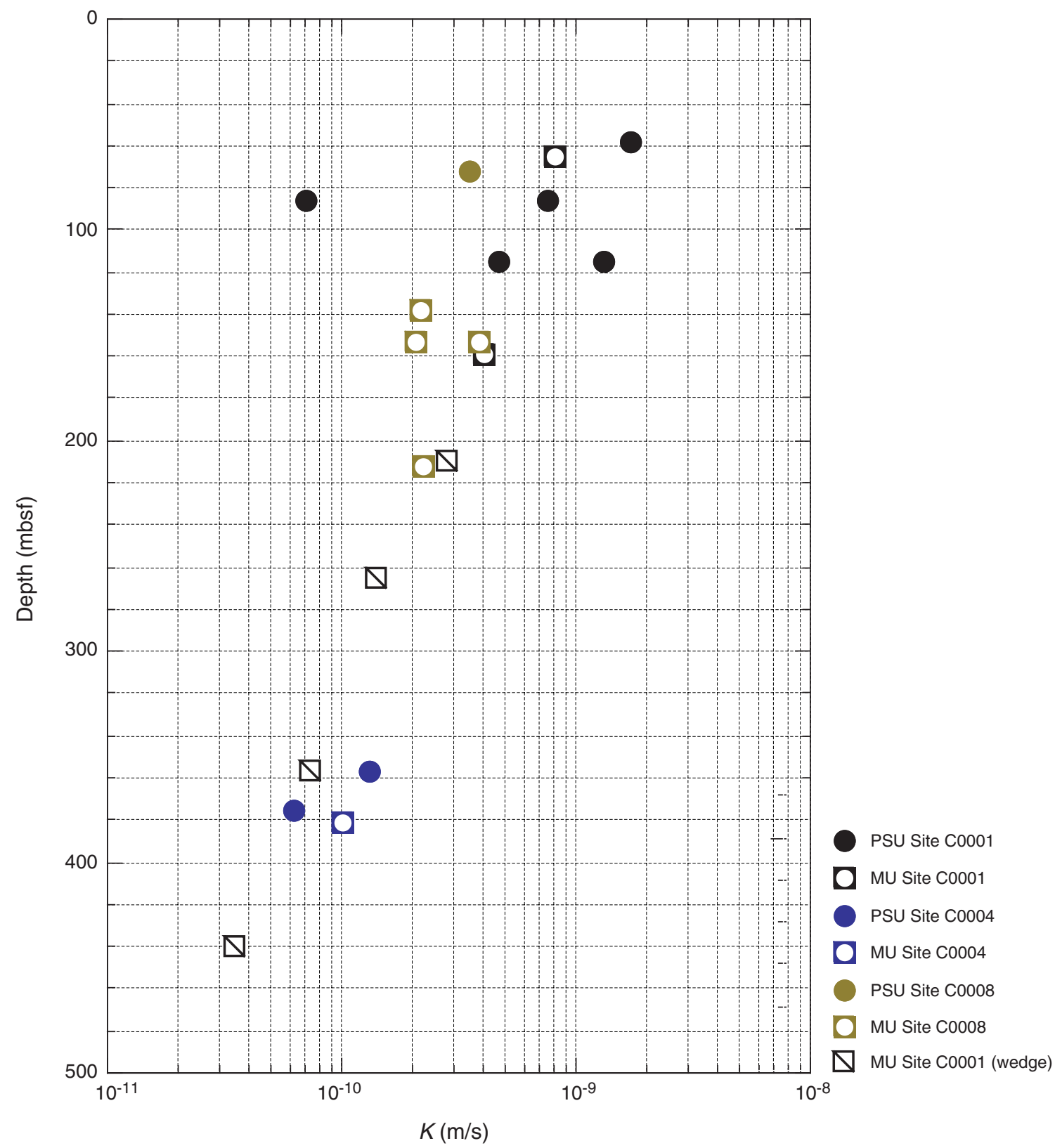


Figure F45. Values of $P_{c}{ }^{\prime}$ for each experiment plotted as a function of depth. Curves showing the expected hydrostatic effective stress $\left(P_{\mathrm{o}}\right)$ for each drill site are shown for comparison. Casag $=$ Casagrande method, $\mathrm{SED}=$ strain energy density (work-stress) method.

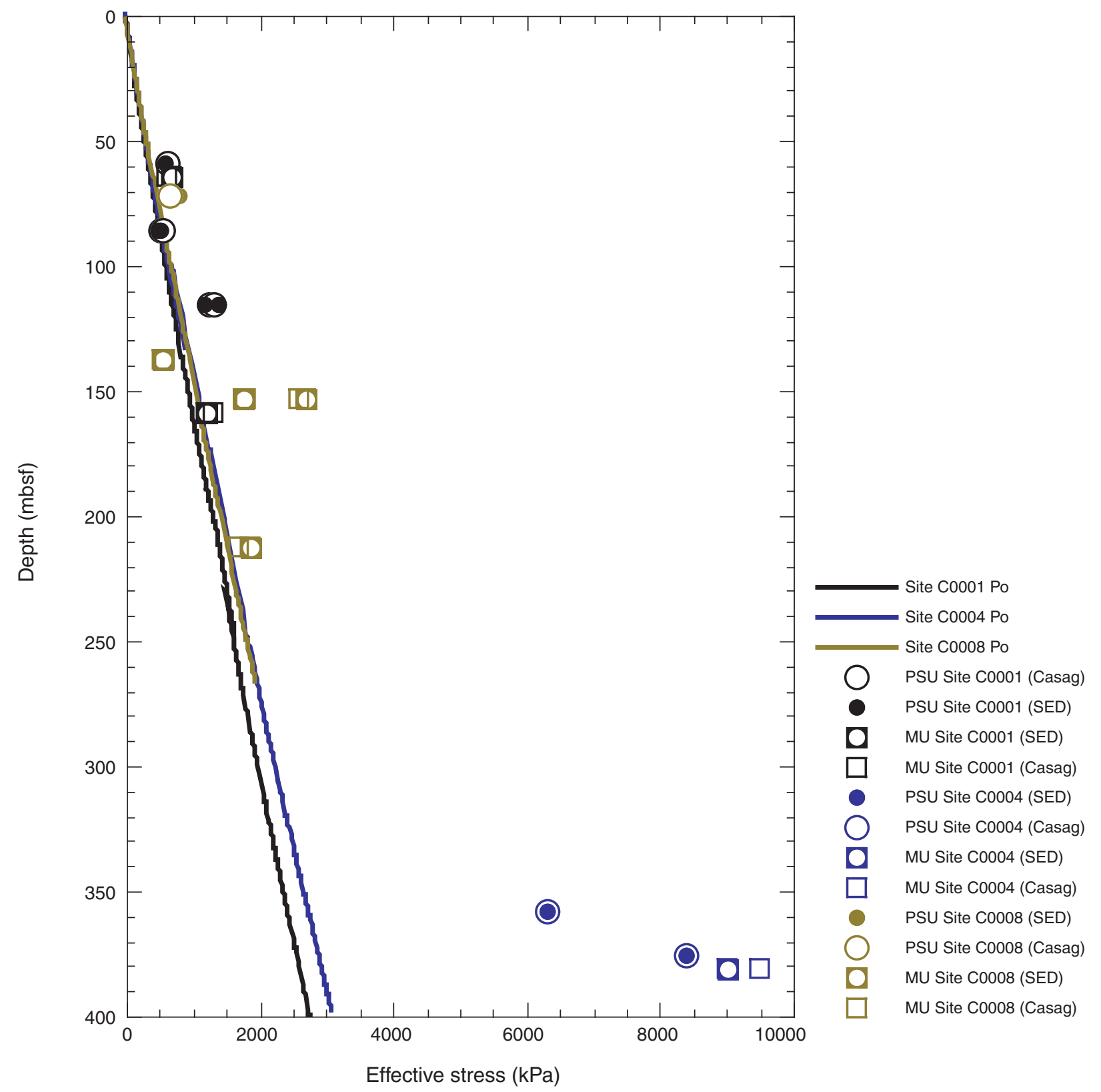


Figure F46. Rose diagrams of ESEM fabric results for samples from Site C0001, showing particle orientations (apparent long axis) binned in $10^{\circ}$ increments.
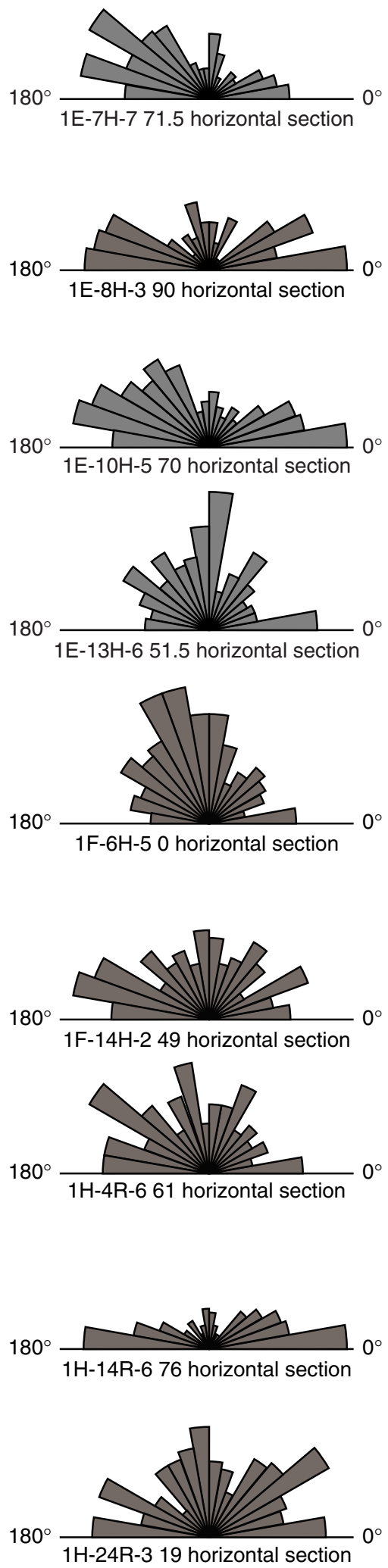
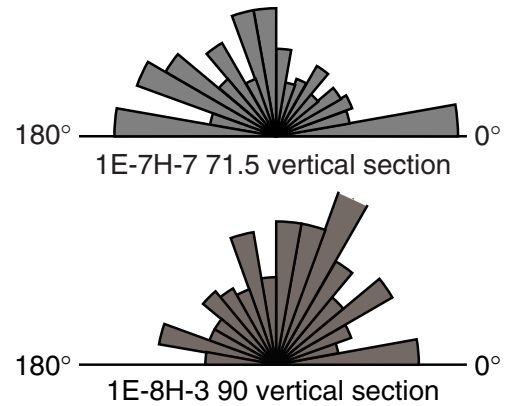

$180^{\circ}$
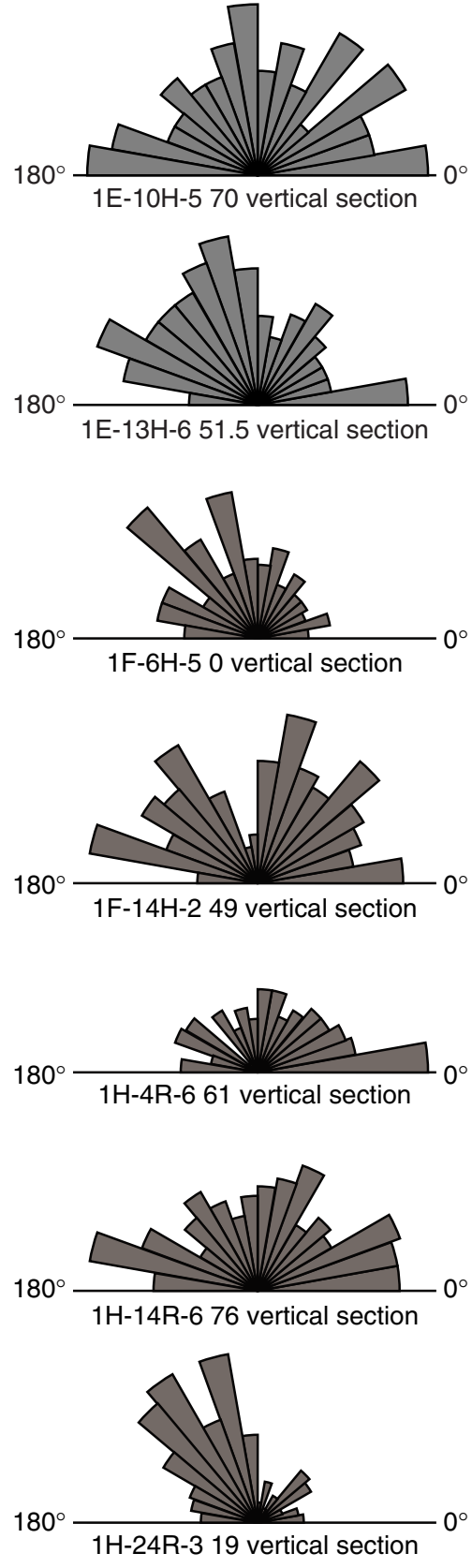
Figure F47. Rose diagrams of ESEM fabric results for samples from Site C0004 (excluding Sample C0004D-47R2, for which a sample for ESEM analysis was not obtained), showing particle orientations (apparent long axis) binned in $10^{\circ}$ increments.
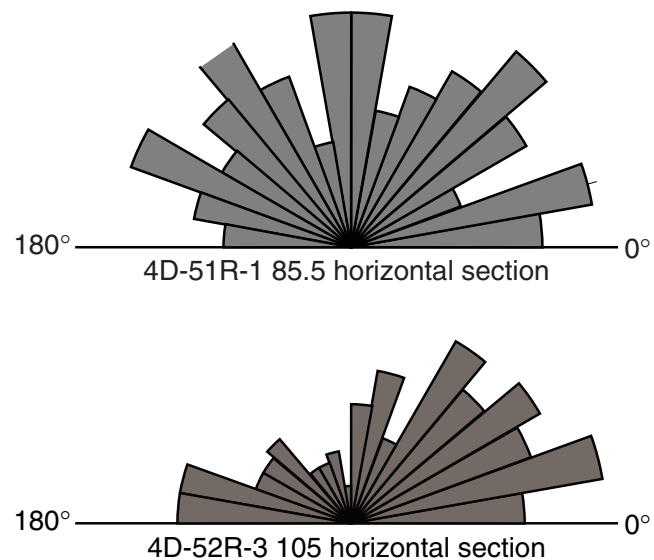
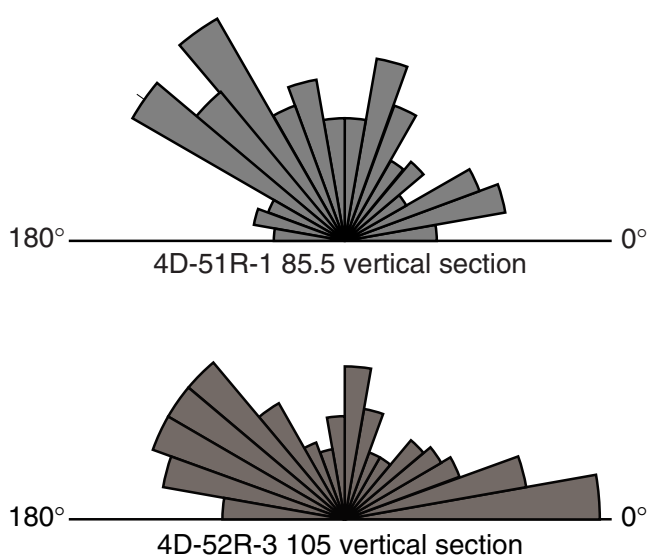
Figure F48. Rose diagrams of ESEM fabric results for samples from Site C0008, showing particle orientations (apparent long axis) binned in $10^{\circ}$ increments.
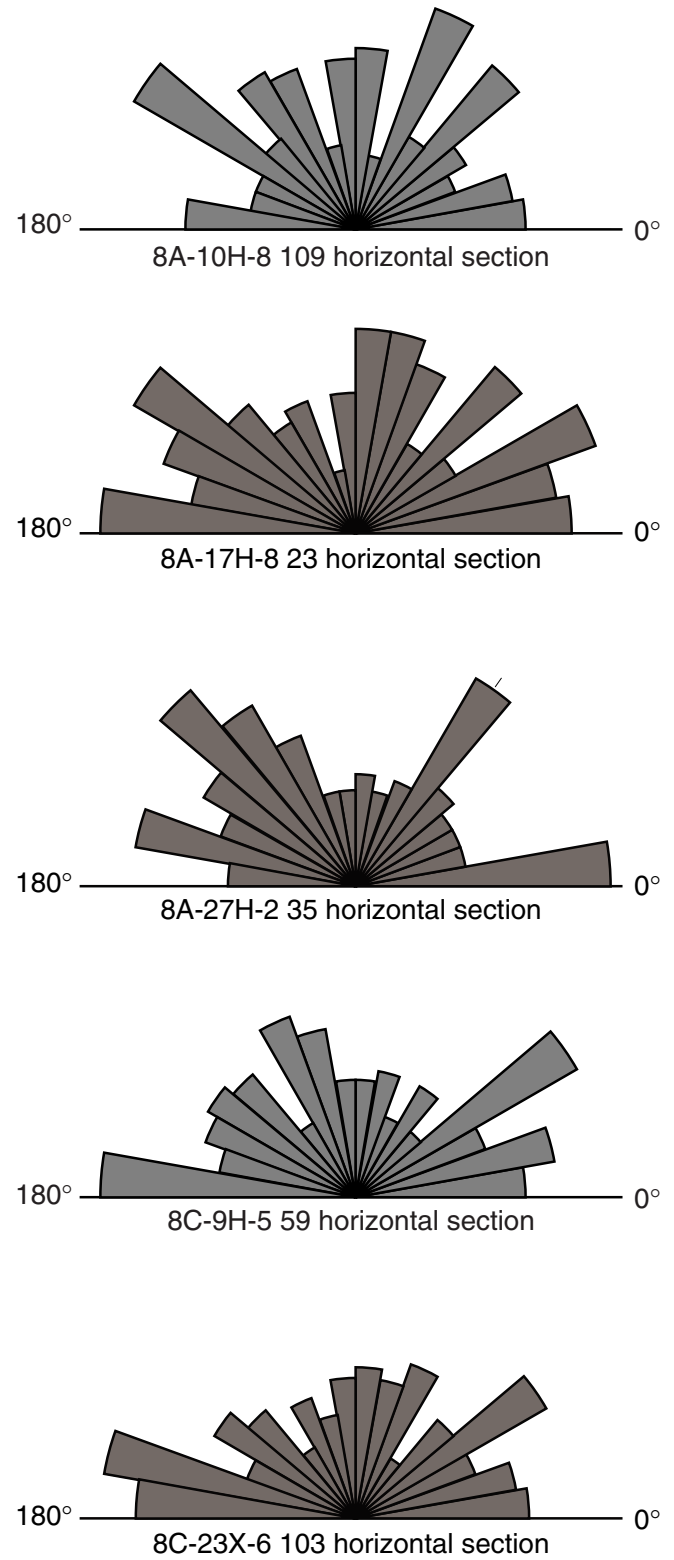
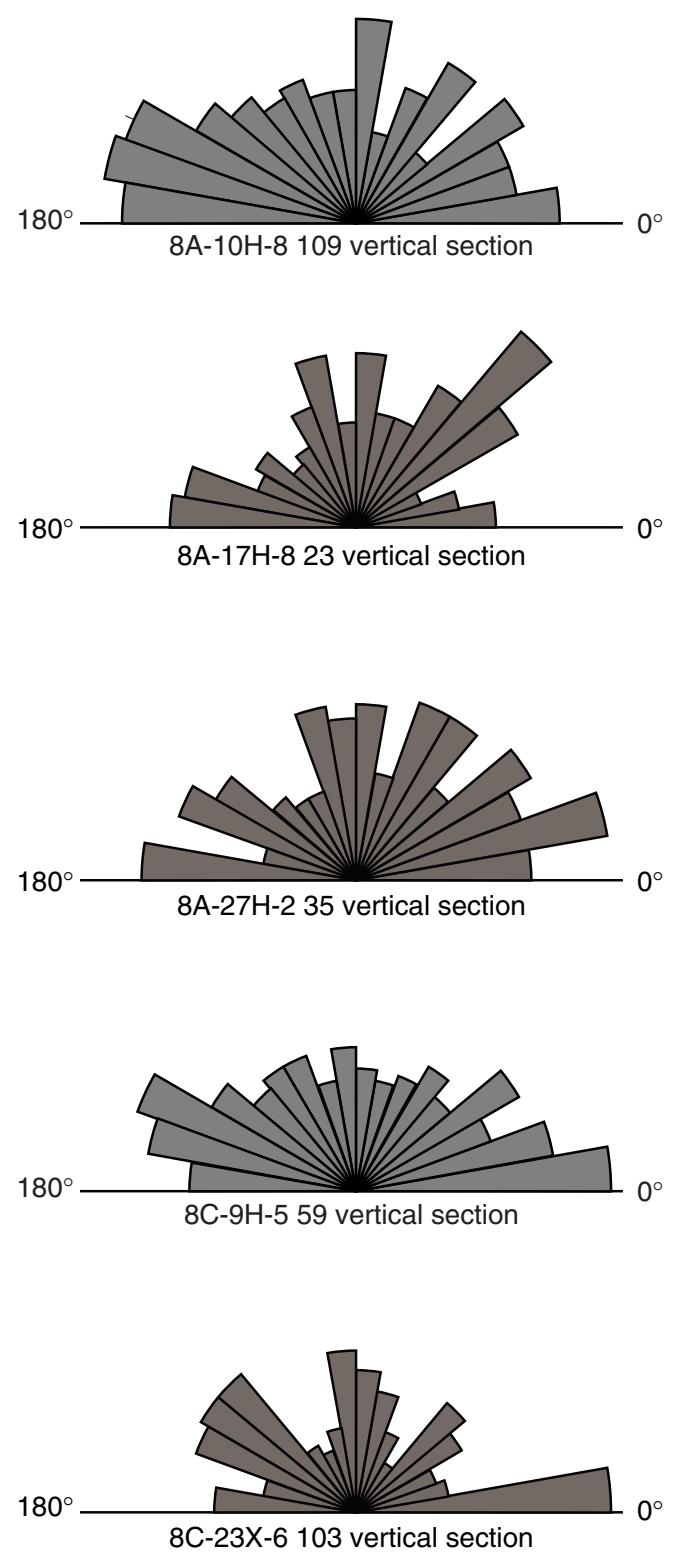
Figure F49. Orientation frequency curves for samples from Site C0001.
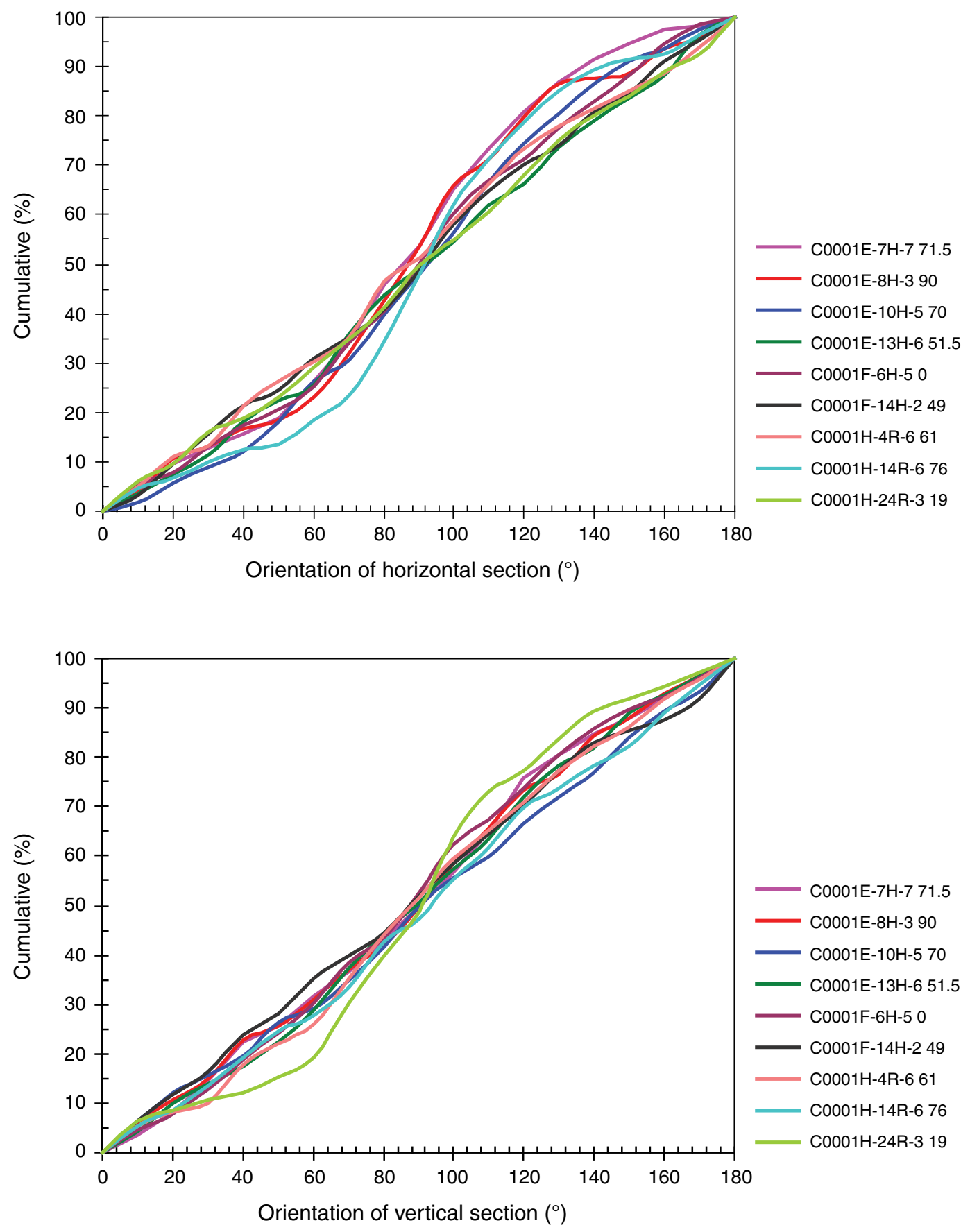
Figure F50. Orientation frequency curves for samples from Site C0004 (excluding Sample C0004D-47R-2, for which a sample for ESEM analysis was not obtained).
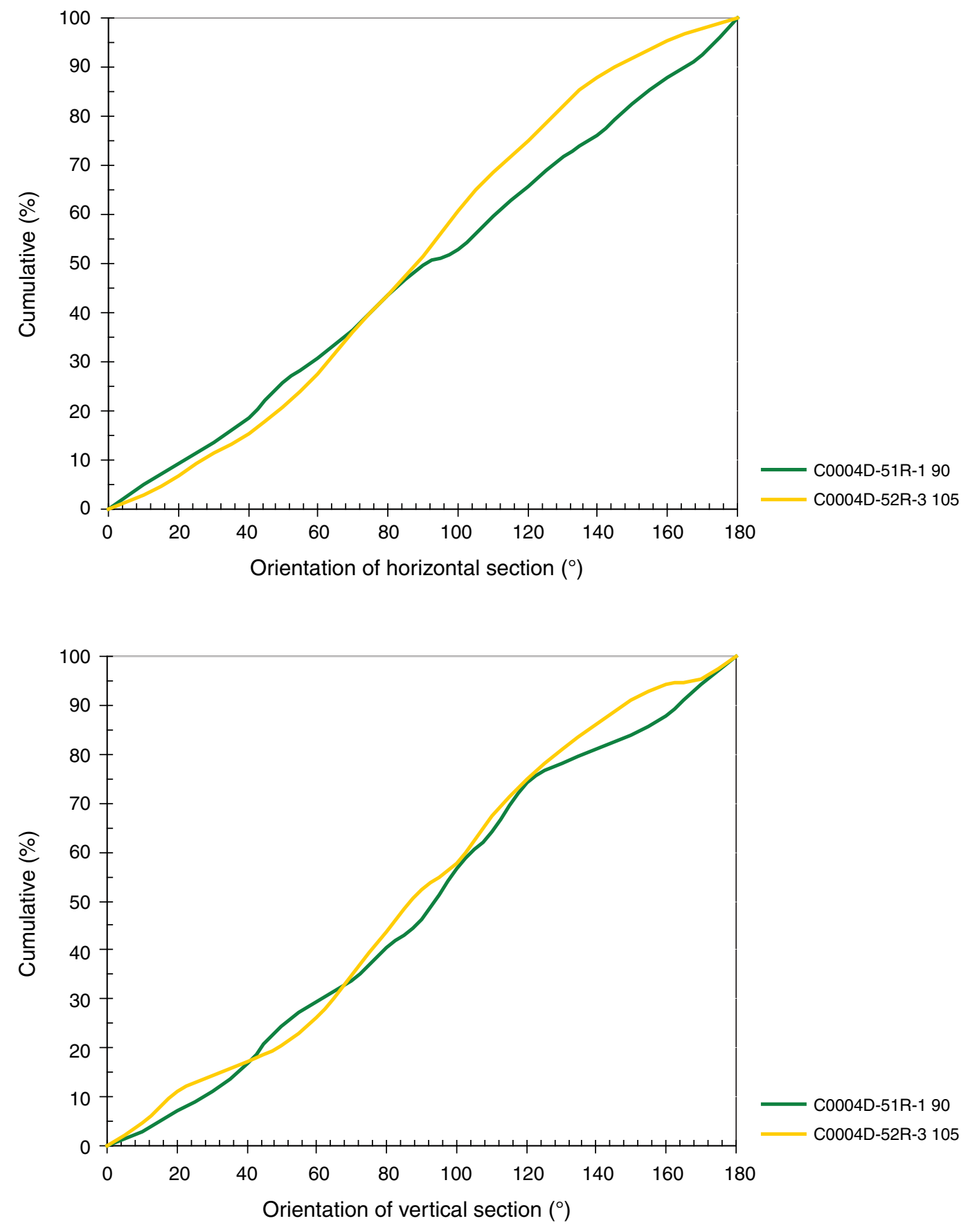
Figure F51. Orientation frequency curves for samples from Site C0008.
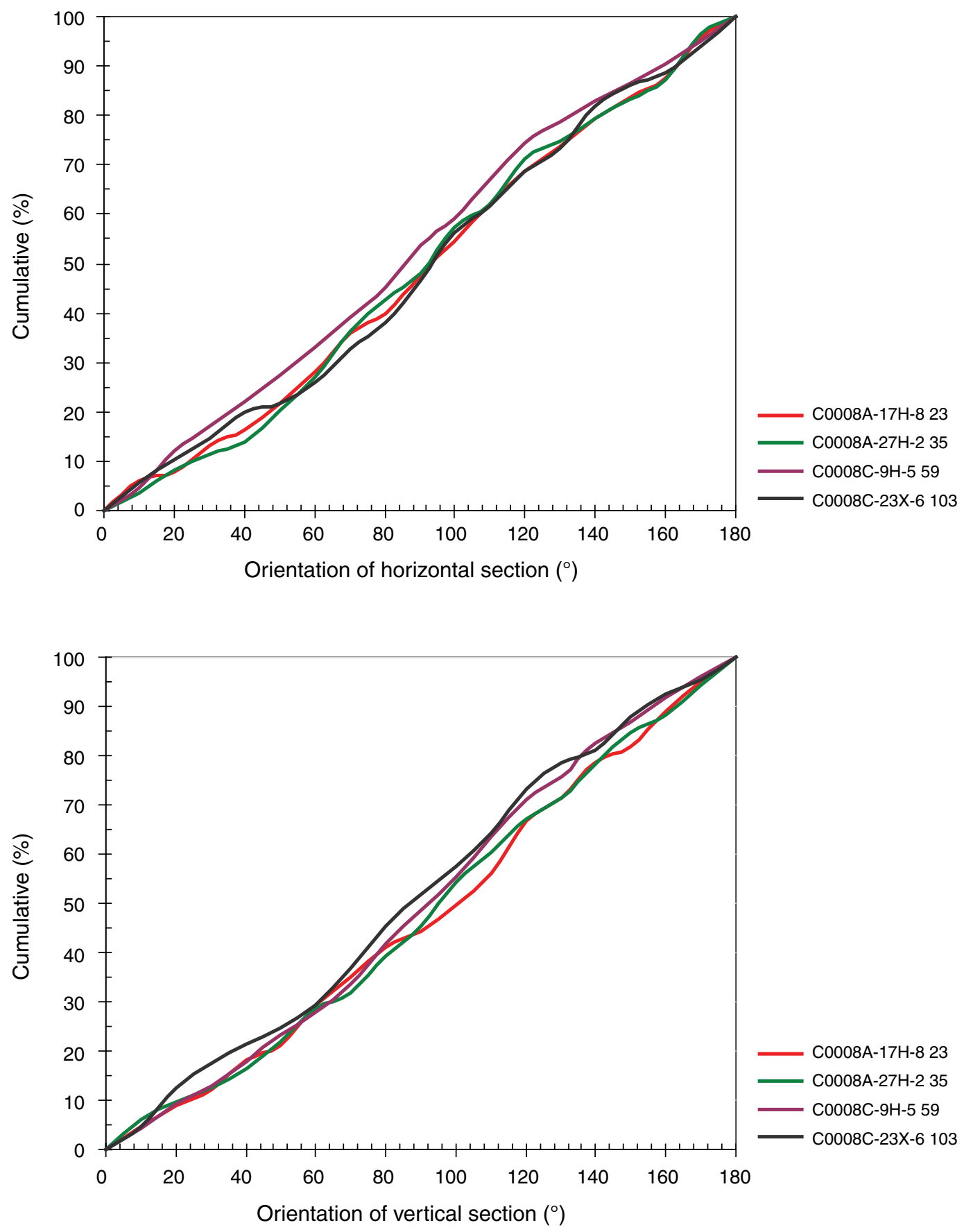
Table T1. Results of fabric analyses by statistical calculation, Sites C0001, C0004, and C0008. (See table note.)

\begin{tabular}{|c|c|c|c|c|c|c|c|}
\hline \multirow[b]{2}{*}{$\begin{array}{l}\text { Core, section, } \\
\text { interval }(\mathrm{cm})\end{array}$} & \multirow[b]{2}{*}{$\begin{array}{l}\text { Depth } \\
\text { (mbsf) }\end{array}$} & \multicolumn{3}{|c|}{ Horizontal section } & \multicolumn{3}{|c|}{ Vertical section } \\
\hline & & $\begin{array}{c}\text { Grains of } \\
\text { count }\end{array}$ & $\begin{array}{l}\text { Degree of } \\
\text { orientation } \\
\left(^{\circ}\right)\end{array}$ & $\begin{array}{l}\text { Index of } \\
\text { orientation }\end{array}$ & $\begin{array}{c}\text { Grains of } \\
\text { count }\end{array}$ & $\begin{array}{c}\text { Degree of } \\
\text { orientation } \\
\left({ }^{\circ}\right)\end{array}$ & $\begin{array}{l}\text { Index of } \\
\text { orientation }\end{array}$ \\
\hline \multicolumn{8}{|l|}{ 315-C0001E- } \\
\hline $7 \mathrm{H}-7,71.5$ & 57.45 & 294 & 42.3 & 0.42 & 260 & 49.9 & 0.31 \\
\hline $8 \mathrm{H}-3,90$ & 64.36 & 169 & 45.5 & 0.37 & 241 & 51.1 & 0.29 \\
\hline $10 \mathrm{H}-5,70$ & 84.73 & 309 & 44.5 & 0.38 & 309 & 54.7 & 0.24 \\
\hline $13 \mathrm{H}-6,51.5$ & 114.30 & 270 & 51.9 & 0.28 & 301 & 50.4 & 0.30 \\
\hline \multicolumn{8}{|l|}{ 315-C0001F- } \\
\hline $6 \mathrm{H}-5,0$ & 158.41 & 205 & 49.4 & 0.32 & 265 & 49.0 & 0.32 \\
\hline $14 \mathrm{H}-2,49$ & 209.52 & 178 & 53.0 & 0.27 & 171 & 53.9 & 0.25 \\
\hline \multicolumn{8}{|l|}{ 315-C0001H- } \\
\hline $4 \mathrm{R}-6,61$ & 264.78 & 221 & 52.8 & 0.27 & 232 & 50.6 & 0.30 \\
\hline $14 \mathrm{R}-6,76$ & 356.42 & 223 & 41.6 & 0.42 & 209 & 53.9 & 0.25 \\
\hline 24R-3, 19 & 440.53 & 226 & 54.9 & 0.24 & 261 & 43.2 & 0.40 \\
\hline \multicolumn{8}{|l|}{ 316-C0004D- } \\
\hline $51 \mathrm{R}-1,61$ & 373.71 & 317 & 54.2 & 0.25 & 243 & 51.6 & 0.29 \\
\hline $52 \mathrm{R}-3,105$ & 380.74 & 272 & 44.9 & 0.38 & 244 & 48.5 & 0.33 \\
\hline \multicolumn{8}{|l|}{ 316-C0008A- } \\
\hline $17 \mathrm{H}-8,23$ & 137.21 & 252 & 52.2 & 0.27 & 214 & 53.3 & 0.26 \\
\hline $27 \mathrm{H}-2,35$ & 212.05 & 173 & 53.1 & 0.27 & 214 & 49.7 & 0.31 \\
\hline \multicolumn{8}{|l|}{ 316-C0008C- } \\
\hline $9 \mathrm{H}-5,59$ & 71.64 & 259 & 52.9 & 0.27 & 258 & 50.4 & 0.30 \\
\hline $23 X-6,103$ & 152.73 & 231 & 52.8 & 0.27 & 239 & 53.3 & 0.26 \\
\hline $23 X-6,114$ & 152.84 & - & - & - & - & - & - \\
\hline
\end{tabular}

Note: Slope is the slope of the particle orientation frequency curve as shown in Figures F48, F49, and F50. 
Table T2. Notation and units for variables used in this chapter. (See table notes.)

\begin{tabular}{|c|c|c|c|}
\hline Variable & Definition & Dimension & Unit \\
\hline$C_{c}$ & Compression index & - & - \\
\hline$C_{v}$ & Coefficient of consolidation & $\mathrm{L}^{2} / \mathrm{T}$ & $\mathrm{m}^{2} / \mathrm{s}$ \\
\hline$d$ & Degree of clast orientation & Dimensionless & - \\
\hline$e$ & Void ratio & Dimensionless & - \\
\hline$e_{\mathrm{i}}$ & Initial specimen void ratio & Dimensionless & - \\
\hline$h$ & Specimen height & $\mathrm{L}$ & $\mathrm{mm}$ \\
\hline$h_{\mathrm{o}}$ & Specimen height at beginning of CRS stage & $\mathrm{L}$ & $\mathrm{mm}$ \\
\hline$i$ & Index of clast orientation & Dimensionless & - \\
\hline$K$ & Hydraulic conductivity & $\mathrm{L} / \mathrm{T}$ & $\mathrm{m} / \mathrm{s}$ \\
\hline$k$ & Intrinsic permeability & $\mathrm{L}^{2}$ & $\mathrm{~m}^{2}$ \\
\hline$m_{\mathrm{v}}$ & Coefficient of volume compressibility & $\mathrm{LT}^{2} / \mathrm{M}$ & $1 / \mathrm{kPa}$ \\
\hline OCR & Overconsolidation ratio & Dimensionless & - \\
\hline$P_{c}^{\prime}$ & Preconsolidation stress & $\mathrm{M} / \mathrm{LT}^{2}$ & $\mathrm{kPa}$ \\
\hline$P_{0}$ & Hydrostatic effective stress & $\mathrm{M} / \mathrm{LT}^{2}$ & $\mathrm{kPa}$ \\
\hline SED & Strain energy density & $\mathrm{M} / \mathrm{LT}^{2}$ & $\mathrm{~kJ} / \mathrm{m}^{3}$ \\
\hline$u$ & Base pore pressure & $\mathrm{M} / \mathrm{LT}^{2}$ & $\mathrm{kPa}$ \\
\hline$u_{\mathrm{b}}$ & Backpressure & $\mathrm{M} / \mathrm{LT}^{2}$ & $\mathrm{kPa}$ \\
\hline$\gamma_{w}$ & Unit weight of pore water & $M / L^{2} T^{2}$ & $\mathrm{kN} / \mathrm{m}^{3}$ \\
\hline$\Delta_{\mathrm{u}}$ & Excess basal pore pressure & $\mathrm{M} / \mathrm{LT}^{2}$ & $\mathrm{kPa}$ \\
\hline$\varepsilon$ & Strain & Dimensionless & - \\
\hline$\dot{\varepsilon}$ & Strain rate & $1 / \mathrm{T}$ & $1 / \mathrm{s}$ \\
\hline$v$ & Dynamic fluid viscosity & $\mathrm{M} / \mathrm{LT}$ & $\mathrm{Pa} \cdot \mathrm{s}$ \\
\hline$\sigma_{\mathrm{a}}$ & Axial stress & $\mathrm{M} / \mathrm{LT}^{2}$ & $\mathrm{kPa}$ \\
\hline$\sigma_{a}^{\prime}$ & Effective axial stress & $\mathrm{M} / \mathrm{LT}^{2}$ & $\mathrm{kPa}$ \\
\hline$\phi$ & Angle of clast orientation & - & Degrees \\
\hline
\end{tabular}

Notes: CRS $=$ constant rate of strain. $-=$ not applicable . 
Table T3. Summary of sample data and experimental results, organized by drill site and depth. (See table notes.)

\begin{tabular}{|c|c|c|c|c|c|c|c|c|c|c|c|c|c|}
\hline \multicolumn{3}{|c|}{ Test information } & \multicolumn{2}{|c|}{ Test conditions } & \multicolumn{3}{|c|}{ Specimen data } & \multicolumn{6}{|c|}{ Consolidation data } \\
\hline Test & Hole, core, section & $\begin{array}{l}\text { Depth } \\
\text { (mbsf) }\end{array}$ & $\begin{array}{c}\text { Strain rate } \\
(\% / h)\end{array}$ & $u_{\mathrm{b}}(\mathrm{kPa})$ & $e_{\mathrm{i}}$ & $h_{\mathrm{o}}$ & $\begin{array}{l}\text { Diameter } \\
\quad(\mathrm{mm})\end{array}$ & $\mathrm{C}_{\mathrm{c}}$ & $\begin{array}{c}P_{\mathrm{c}}^{\prime} \text { Casag } \\
(\mathrm{kPa})\end{array}$ & $\begin{array}{c}P_{\mathrm{c}}^{\prime} \text { SED } \\
(\mathrm{kPa})\end{array}$ & $P_{\mathrm{O}}$ & $\begin{array}{c}\text { OCR } \\
\text { Casag }\end{array}$ & OCR SED \\
\hline U-068 & C0001E-7H-7 & 58.25 & 0.20 & 300 & 1.69 & 19.67 & 36.6 & 0.713 & 609 & 553 & 339 & 1.80 & 1.63 \\
\hline MU-1 & C0001E-8H-3 & 64.37 & 0.50 & 201 & 1.45 & 24.36 & 41.0 & 0.535 & 585 & 678 & 380 & 1.54 & 1.78 \\
\hline U-071 & C0001E-10H-5 & 85.22 & 0.25 & 300 & 1.86 & 20.07 & 50.0 & 0.651 & 486 & 458 & 510 & 0.95 & 0.90 \\
\hline U-088 & $\mathrm{C} 0001 \mathrm{E}-10 \mathrm{H}-5$ & 85.22 & 0.50 & 300 & 1.59 & 14.58 & 36.6 & 0.603 & 527 & 475 & 510 & 1.03 & 0.93 \\
\hline U-085 & C0001E-13H-6 & 114.88 & 0.37 & 300 & 1.69 & 20.07 & 36.6 & 0.790 & 1271 & 1138 & 708 & 1.80 & 1.61 \\
\hline U-081 & C0001E-13H-6 & 114.88 & 0.25 & 300 & 1.35 & 19.96 & 50.0 & 0.686 & 1231 & 1341 & 708 & 1.74 & 1.89 \\
\hline MU-2 & C0001F-6H-5 & 158.41 & 0.70 & 203 & 1.64 & 22.36 & 41.0 & 0.762 & 1280 & 1180 & 1003 & 1.28 & 1.18 \\
\hline MU-3 & $\mathrm{C} 0001 \mathrm{~F}-14 \mathrm{H}-2$ & 209.38 & 0.70 & 202 & 1.31 & 23.35 & 41.0 & 0.721 & NA & NA & NA & NA & NA \\
\hline MU-4 & $\mathrm{C} 0001 \mathrm{H}-4 \mathrm{R}-6$ & 264.59 & 0.70 & 202 & 1.44 & 24.15 & 41.0 & 1.034 & NA & NA & NA & NA & NA \\
\hline MU-5 & $\mathrm{C} 0001 \mathrm{H}-14 \mathrm{R}-6$ & 356.42 & 0.70 & 202 & 1.28 & 18.36 & 41.0 & 1.032 & NA & NA & NA & NA & NA \\
\hline MU-6 & $\mathrm{C} 0001 \mathrm{H}-24 \mathrm{R}-3$ & 440.34 & 0.70 & 202 & 0.93 & 24.55 & 41.0 & 1.058 & NA & NA & NA & NA & NA \\
\hline U-136 & C0004D-47R-2 & 357.11 & 0.21 & 300 & 1.06 & 20.03 & 36.6 & 0.768 & 6289 & 6300 & 2678 & 2.35 & 2.35 \\
\hline U-140 & C0004D-51R-2 & 375.08 & 0.23 & 300 & 0.79 & 19.50 & 36.6 & 0.746 & 8387 & 8375 & 2836 & 2.96 & 2.95 \\
\hline MU-7 & C0004D-52R-3 & 380.81 & 0.50 & 202 & 0.73 & 18.77 & 41.0 & 0.624 & 9484 & 9000 & 2887 & 3.29 & 3.12 \\
\hline $\mathrm{U}-127$ & $\mathrm{C} 0008 \mathrm{C}-9 \mathrm{H}-5$ & 71.64 & 0.68 & 400 & 0.98 & 20.09 & 50.0 & 0.419 & 628 & 783 & 487 & 1.29 & 1.61 \\
\hline MU-8 & C0008A-17H-8 & 137.23 & 0.50 & 203 & 1.19 & 24.34 & 41.0 & 0.425 & 570 & 522 & 940 & 0.61 & 0.56 \\
\hline MU-10 & C0008C-23X-6 & 152.73 & 0.50 & 202 & 1.18 & 22.35 & 41.0 & 0.616 & 1764 & 1750 & 1055 & 1.67 & 1.66 \\
\hline MU-11 & C0008C-23X-6 & 152.84 & 0.50 & 205 & 1.03 & 23.35 & 41.0 & 0.609 & 2559 & 2690 & 1056 & 2.42 & 2.55 \\
\hline MU-9 & C0008A-27H-2 & 211.95 & 0.50 & 200 & 1.34 & 23.35 & 41.0 & 0.638 & 1680 & 1850 & 1569 & 1.07 & 1.18 \\
\hline
\end{tabular}

Notes: ${ }^{*}=$ no $P_{\mathrm{c}}{ }^{\prime}$ values estimated for these samples in wedge; in situ values of e taken as value at yield stress. $C_{\mathrm{c}}$ values based on uniaxial stress path, so may not reflect real loading path in wedge. $K$ values computed from laboratory-derived values of intrinsic permeability and accounting for in situ fluid viscosity as a function of temperature. Casag = Casagrande method, SED = strain energy density, OCR = overconsolidation ratio, SQD = sample quality designation (Lunne et al., 1997).

\begin{tabular}{|c|c|c|c|c|c|c|c|c|}
\hline \multicolumn{3}{|c|}{ Test information } & \multicolumn{3}{|c|}{ Projected in situ properties* } & \multicolumn{3}{|c|}{ Sample quality designation } \\
\hline Test & Hole, core, section & $\begin{array}{l}\text { Depth } \\
\text { (mbsf) }\end{array}$ & $\mathrm{e}$ & $K(\mathrm{~m} / \mathrm{s})$ & $k\left(\mathrm{~m}^{2}\right)$ & $\Delta \mathrm{e}$ & $\Delta \mathrm{e} / \mathrm{e}_{\mathrm{i}}$ & SQD \\
\hline U-068 & C0001E-7H-7 & 58.25 & 1.58 & $1.71 \mathrm{E}-09$ & $2.84 \mathrm{E}-16$ & 0.11 & 0.07 & B \\
\hline MU-1 & $\mathrm{C} 0001 \mathrm{E}-8 \mathrm{H}-3$ & 64.37 & 1.14 & $8.05 \mathrm{E}-10$ & $1.33 \mathrm{E}-16$ & 0.31 & 0.21 & $\mathrm{D}$ \\
\hline U-071 & $\mathrm{C} 0001 \mathrm{E}-10 \mathrm{H}-5$ & 85.22 & 1.69 & $7.46 \mathrm{E}-10$ & $1.20 \mathrm{E}-16$ & 0.17 & 0.09 & C \\
\hline U-088 & $\mathrm{C} 0001 \mathrm{E}-10 \mathrm{H}-5$ & 85.22 & 1.40 & $6.95 \mathrm{E}-11$ & $1.12 \mathrm{E}-17$ & 0.19 & 0.12 & C \\
\hline U-085 & C0001E-13H-6 & 114.88 & 1.56 & $4.62 \mathrm{E}-10$ & $7.11 \mathrm{E}-17$ & 0.13 & 0.08 & C \\
\hline U-081 & C0001E-13H-6 & 114.88 & 1.20 & $1.31 \mathrm{E}-09$ & $2.02 \mathrm{E}-16$ & 0.15 & 0.11 & C \\
\hline MU-2 & $\mathrm{C} 0001 \mathrm{~F}-6 \mathrm{H}-5$ & 158.41 & 1.27 & $4.02 \mathrm{E}-10$ & $5.80 \mathrm{E}-17$ & 0.37 & 0.23 & D \\
\hline MU-3 & $\mathrm{C} 0001 \mathrm{~F}-14 \mathrm{H}-2$ & 209.38 & 1.08 & $2.83 \mathrm{E}-10$ & $3.83 \mathrm{E}-17$ & 0.23 & 0.17 & $\mathrm{D}$ \\
\hline MU-4 & $\mathrm{C} 0001 \mathrm{H}-4 \mathrm{R}-6$ & 264.59 & 1.25 & $1.41 \mathrm{E}-10$ & $1.80 \mathrm{E}-17$ & 0.19 & 0.13 & $\mathrm{D}$ \\
\hline MU-5 & C0001H-14R-6 & 356.42 & 1.03 & $7.42 \mathrm{E}-11$ & $8.50 \mathrm{E}-18$ & 0.25 & 0.20 & $\mathrm{D}$ \\
\hline MU-6 & $\mathrm{C} 0001 \mathrm{H}-24 \mathrm{R}-3$ & 440.34 & 0.77 & $3.50 \mathrm{E}-11$ & $3.65 \mathrm{E}-18$ & 0.16 & 0.18 & $\mathrm{D}$ \\
\hline U-136 & C0004D-47R-2 & 357.11 & 0.90 & $1.29 \mathrm{E}-10$ & $1.37 \mathrm{E}-17$ & 0.16 & 0.15 & $\mathrm{D}$ \\
\hline U-140 & C0004D-51R-2 & 375.08 & 0.71 & $6.25 \mathrm{E}-11$ & $6.50 \mathrm{E}-18$ & 0.08 & 0.10 & C \\
\hline MU-7 & C0004D-52R-3 & 380.81 & 0.58 & $1.01 \mathrm{E}-10$ & $1.05 \mathrm{E}-17$ & 0.15 & 0.20 & $\mathrm{D}$ \\
\hline U-127 & $\mathrm{C} 0008 \mathrm{C}-9 \mathrm{H}-5$ & 71.64 & 0.89 & $3.51 \mathrm{E}-10$ & $5.58 \mathrm{E}-17$ & 0.09 & 0.09 & C \\
\hline MU-8 & C0008A-17H-8 & 137.23 & 0.90 & $2.15 \mathrm{E}-10$ & $3.10 \mathrm{E}-17$ & 0.29 & 0.24 & $\mathrm{D}$ \\
\hline MU-10 & C0008C-23X-6 & 152.73 & 1.00 & $3.81 \mathrm{E}-10$ & $5.22 \mathrm{E}-17$ & 0.18 & 0.15 & $\mathrm{D}$ \\
\hline MU-11 & C0008C-23X-6 & 152.84 & 0.89 & $2.04 \mathrm{E}-10$ & $2.79 \mathrm{E}-17$ & 0.14 & 0.14 & $\mathrm{D}$ \\
\hline MU-9 & C0008A-27H-2 & 211.95 & 1.04 & $2.22 \mathrm{E}-10$ & $2.89 \mathrm{E}-17$ & 0.30 & 0.22 & $\mathrm{D}$ \\
\hline
\end{tabular}

